\title{
Descrição de nove espécies novas de Phenacogaster (Ostariophysi: Characiformes: Characidae) e comentários sobre as demais espécies do gênero
}

\author{
Zilda Margarete Seixas de Lucena' ${ }^{1} \&$ Luiz Roberto Malabarba²
}

\author{
${ }^{1}$ Museu de Ciências e Tecnologia da Pontifícia Universidade Católica do Rio Grande do Sul. Avenida Ipiranga 6681, \\ 90619-900 Porto Alegre, Rio Grande do Sul, Brazil. E-mail: margarete@pucrs.br \\ 2 Departamento de Zoologia, Universidade Federal do Rio Grande do Sul. Avenida Bento Gonçalves 9500, 91501 -970 Porto \\ Alegre, Rio Grande do Sul, Brazil. malabarb@ufrgs.br
}

\begin{abstract}
Description of nine new species of Phenacogaster (Ostariophysi: Characiformes: Characidae) and notes on the other species of genus. Nine new species of Phenacogaster Eigenmann, 1907 are described: Phenacogaster capitulatus sp. nov. from the Neshuya River system, Ucayali River basin; Phenacogaster maculoblongus sp. nov. from the upper Cuyuni River, and tributaries of the lower Orinoco River; Phenacogaster napoatilis sp. nov. from the Napo River system, upper Amazon River basin; Phenacogaster ojitatus sp. nov. from the Xingu River system; Phenacogaster prolatus sp. nov. from the Orinoco River, canal Casiquiare and upper and middle Negro River; Phenacogaster retropinnus sp. nov. from the Negro, Madeira and Xingu river systems; Phenacogaster simulatus sp. nov. from the Potaro River, Essequibo drainage; Phenacogaster wayampi sp. nov. from the Oiapoque River, and Phenacogaster wayana sp. nov. from the Corantijn (Suriname), Maroni, Mana, Sinnamary and Approuague rivers (French Guiana). The geographic distribution of $P$. megalostictus, previously recorded for the Negro River, Amazon River system, is restricted to the Essequibo River system, Guiana. The distribution of P. carteri, previously known only from the type-locality (Cuyuni River, Guyana), is extended to the lower Orinoco River. The reduction of the latero-sensory canal, mentioned in the literature as an autapomorphy for $P$. tegatus was observed in three additional species of Phenacogaster. The posterior humeral spot, found only in P. tegatus, is herein considered autapomorphic for the species. Diagnoses are given for previously described species based on the analysis of type material and additional specimens, and a key to the species of the genus is provided.
\end{abstract}

KEY WORDS. Biodiversity; neotropical fish; taxonomy.

Phenacogaster Eigenmann, 1907 compreende um grupo de espécies de peixes de pequeno tamanho (35 a $61 \mathrm{~mm}$ de comprimento padrão), denominadas popularmente lambaris, glasstetras, mojaritas ou yaya. As espécies do gênero compõem a ictiofauna de quase todos os grandes sistemas fluviais da América do Sul a leste dos Andes (Fig. 1), ocorrendo nas bacias dos rios Amazonas, Orinoco, Tocantins, Araguaia, Paraguai, São Francisco, e rios costeiros do norte e nordeste do Brasil e Guianas, e ainda segundo CasciotTa et al. (2003), no médio Rio Paraná. Entretanto, desconhece-se sua ocorrência no Rio Uruguai, no alto Rio Paraná, nos rios costeiros entre o Rio Piranhas (estado da Paraíba) e o Rio São Francisco no Brasil, e nos rios costeiros desde imediatamente ao sul do Rio Paraguaçu (estado da Bahia, Brasil) até a Argentina. Habitam diversos ambientes, desde riachos correntosos com fundo de areia e rochas, posicionando-se contra a corrente (Planquette et al. 1996: 216), a rios de correnteza média a fraca, com substrato de areia e lodo.

Phenacogaster é um grupo monofilético, distinguindo-se dos demais gêneros de Characidae pelas seguintes sinapomorfias apresentadas em MaLABARba \& LucEna (1995): presença de duas séries longitudinais de escamas pré-ventrais comparativamente grandes e estreitas, que se estendem lateralmente no corpo; série de dentes da fileira externa do pré-maxilar interrompida, dividida em uma região medial e uma região lateral, nitidamente isoladas por um espaço sem dentes, sendo a região medial composta de dentes tricúspides, e a lateral, de dentes tricúspides e/ou cônicos. Outros caracteres que auxiliam na identificação do gênero incluem: corpo geralmente translúcido, com presença de um amplo pseudotímpano na região umeral, presença de sulcos relativamente bem desenvolvidos no terceiro infraorbital, e presença de neuromastos na cabeça, visualizados principalmente nos sulcos do terceiro infra-orbital.

Neste estudo são descritas nove espécies de Phenacogaster e apresentadas as diagnoses de sete outras espécies: $P$. megalostictus Eigenmann, 1909; P. franciscoensis Eigenmann, 1911; P. tegatus Eigenmann, 1911; P. carteri (Norman, 1934); $P$. calverti (Fowler, 1941), P. jancupa Malabarba \& Lucena, 1995 e P. apletostigma Lucena \& Gama, 2007. As espécies $P$. pectinatus 
(Cope, 1870); P. microstictus Eigenmann, 1909; P. beni Eigenmann, 1911 e P. suborbitalis Ahl, 1936 são reunidas e tratadas aqui como um grupo de ampla distribuição geográfica denominado Complexo P. pectinatus.

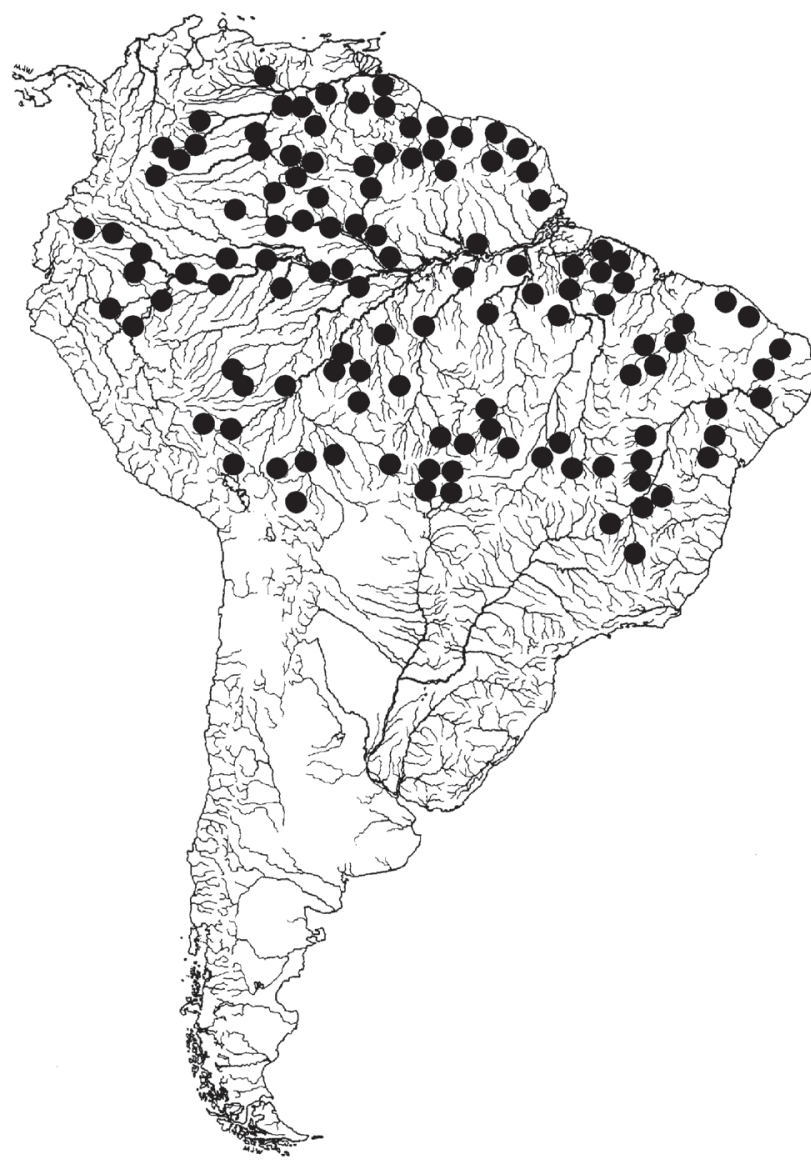

Figura 1. Distribuição das espécies de Phenacogaster com base em material examinado.

\section{MATERIAL E MÉTODOS}

O material examinado neste estudo encontra-se depositado nas seguintes instituições: Academy of Natural Sciences, Philadelphia (ANSP); Auburn University Museum, Alabama (AUM); The Natural History Museum, London (BMNH); California Academy of Sciences, San Francisco (CAS); Field Museum of Natural History, Chicago (FMNH), Instituto Nacional de Pesquisas da Amazônia, Manaus (INPA); Museo de Biologia, Universidad Central de Venezuela, Caracas (MBUCV-V); Museo de la Escuela Politécnica Nacional, Quito, Equador (MEPN); Museu de Ciências e Tecnologia, Pontifícia Universidade Católica do Rio Grande do Sul, Porto Alegre (MCP);
Museum of Comparative Zoology, Cambridge (MCZ); Muséum d'histoire naturelle, Genève (MHNG); Muséum national d'histoire naturelle, Paris (MNHN); Museo de Historia Natural, Universidad Nacional Mayor de San Marcos, Lima (MUSM); Museu Nacional, Rio de Janeiro (MNRJ); Museu de Zoologia da Universidade de São Paulo, São Paulo (MZUSP); Royal Ontario Museum, Toronto (ROM); Florida Museum of Natural History, Gainsville (UF); National Museum of Natural History, Smithsonian Institution, Washington (USNM). Outras siglas utilizadas: (CM) Carnegie Museum, Pittsburgh; (IU) Indiana University, Bloomington.

Na seção Material Examinado, após o número de catálogo, constam entre parênteses o número total de espécimes examinados seguido do comprimento padrão do menor e maior exemplar. O número de espécimes diafanizados e corados, quando houver, segue após o número de exemplares do referido lote, com o comprimento padrão do menor e maior exemplar.

As contagens de vértebras e supraneurais, e parte da descrição da dentição, foram feitas em espécimes diafanizados e corados conforme a técnica de TAYLOR \& VAN Dyke (1985), ou através de radiografias. Na contagem das vértebras estão incluídas as quatro vértebras do aparelho de Weber e a vértebra terminal, usualmente designada como PU1+U1.

A definição das medidas e contagens utilizadas segue FINK \& Weitzman (1974), Malabarba \& Lucena (1995) e Lucena \& Gama (2007). Todas as medidas e contagens, exceto a medida do comprimento do maxilar, foram feitas preferencialmente no lado esquerdo do exemplar, sob estereomicroscópio e com paquímetro digital. Os espécimes foram medidos considerando-se as projeções sobre a linha mediana do corpo, exceto as medidas do comprimento do maxilar, distância do supra-occipital à nadadeira dorsal, distância da nadadeira dorsal à nadadeira adiposa, e comprimento das nadadeiras peitorais e pélvicas, que foram medidas de ponto a ponto. Naqueles exemplares com falta de escamas em ambos os lados do corpo, as contagens foram feitas pelas marcas das escamas na pele. Tais contagens são mencionadas no texto como aproximadas. As proporções e médias foram calculadas através do programa Datax-Biometric Data Management System versão 4.2, elaborado por Roberto Reis e Nelson Fontoura. Os gráficos, testes estatísticos, retas de regressão e respectivas equações, oriundos da análise dos caracteres merísticos e/ou morfométricos, foram feitos com auxílio dos programas SigmaPlot 2.0 e SigmaStat para Windows95 (ambos distribuídos por Jandel Scientific). Quando necessário, as variações dos caracteres merísticos são apresentadas através de Tukey Box Plots, no qual a mediana é representada pela linha vertical mais fraca no interior do retângulo e a média pela linha mais forte; os percentis de 25 e $75 \%$ correspondem às laterais do retângulo; os percentis de 10 e $90 \%$ aos traços verticais curtos situados além do retângulo, e os círculos pretos aos valores abaixo e acima dos percentis de 10 e $90 \%$. Os dados merísticos foram testados quanto a sua normalidade aplicando-se o teste de Kolmogorov-Smirnov. Quando o teste de normalidade falhou, indicando uma distri- 
buição não-paramétrica do caráter, foi aplicado o teste de Kruskall-Wallis Anova para verificar se haviam diferenças significativas entre as populações. Em caso positivo, o método de Dunn foi aplicado para detectar quais pares de espécies diferiam entre si com respeito ao caráter merístico analisado. Nesses pares utilizou-se o teste Mann Whitney Rank. Nas descrições das espécies os caracteres merísticos são apresentados com as suas variações e médias.

Abreviaturas utilizadas: (d\&c) diafanizado e corado, (CP) comprimento padrão, (CC) comprimento da cabeça.

$\mathrm{Na}$ sinonímia das espécies, mencionam-se unicamente os trabalhos referentes a questões nomenclaturais.

\section{TAXONOMIA}

Para efeitos de diagnose, características diferenciais e chave de identificacão, as espécies $P$. pectinatus, $P$. microsticus, $P$. beni e $P$. suborbitalis foram reunidas sob o nome Complexo Phenacogaster pectinatus. Este agrupamento pode ser distinguido das demais espécies do gênero pelo seguinte conjunto de caracteres: mancha umeral presente somente nas fêmeas, usualmente oblíqua e estreita, sua largura menor que a metade do diâmetro horizontal da órbita; mancha no pedúnculo caudal ausente ou restrita a poucos cromatóforos; linha lateral completa; 33-42 raios ramificados na nadadeira anal; origem da nadadeira anal na vertical que passa próxima à origem da nadadeira dorsal; comprimento pré-anal de 45,1-52,5\% do comprimento padrão.

\section{Chave de identificação das espécies de Phenacogaster}

1. Linha lateral incompleta, com 8-13 escamas perfuradas .... 2

1 '. Linha lateral completa, com 34-41 escamas perfuradas .... 5

2. Mancha umeral presente em machos e fêmeas, horizontalmente alongada, situada distante do pseudotímpano, na vertical que passa imediatamente à frente ou pela origem da nadadeira dorsal (sistema do Rio Paraguai) ... P. tegatus

2'. Mancha umeral ausente ou presente somente em fêmeas; oblíqua, estreita, sua largura menor que a metade do diâmetro horizontal da órbita; situa-se próximo ao pseudotímpano, acima da sétima à oitava escama da linha lateral e claramente a frente da vertical que passa pela origem da nadadeira dorsal .... 3

3. Mancha umeral ausente, comprimento do maxilar 6,9-7,6\% do comprimento padrão (em espécimes maiores que $30 \mathrm{~mm} \mathrm{CP}$ ) (drenagem do Rio Cuyuni e baixo Rio Orinoco)

P. carteri

3'. Mancha umeral presente somente nas fêmeas, comprimento do maxilar de $5,8-7,0 \%$ do comprimento padrão (em espécimes maiores que $30 \mathrm{~mm} \mathrm{CP}$ )

.. 4

4. Comprimento do focinho de 5,1-7,0\% do CP. Altura do corpo de 31,6-36,9\% do comprimento padrão (em espécimes maiores que 35,0 mm CP) (drenagem do Rio Napo, alto Rio Amazonas) P. napoatilis sp. nov.
4'. Comprimento do focinho de 4,3-5,3\% do CP. Altura do corpo de $36,0-39,4 \%$ do comprimento padrão (em espécimes maiores que 35,0 mm CP) (drenagem do Rio Neshuya, sistema do Rio Ucayali) P. capitulatus sp. nov.

5. Mancha umeral, em machos, ausente ou restrita a poucos cromatóforos; mancha nas fêmeas presente, usualmente oblíqua e estreita, menor que a metade do diâmetro orbital (alto Rio Amazonas aos rios costeiros do nordeste do Brasil) Complexo P. pectinatus

5'. Mancha umeral presente em machos e fêmeas, conspícua, de forma não semelhante à acima .. 6

6. Altura da mancha umeral maior que o diâmetro orbital, correspondendo aproximadamente à distância da extremidade anterior do focinho até a região posterior da órbita (drenagem do Rio Araguari, Amapá) P. apletostigma

6'. Mancha umeral nunca maior que o diâmetro orbital. Maior ou aproximadamente igual à metade do diâmetro orbital; raramente menor 7

7. 9-21 dentes no maxilar, raramente 21 (sistema do Rio Essequibo, Guiana) ............................................. P. megalostictus

7'. 21-38 dentes no maxilar, raramente 21 ........................... 8

8. Mancha do pedúnculo caudal comparativamente alongada e estreita, estendendo-se posteriormente até a extremidade dos raios medianos da nadadeira caudal; seu limite anterior alcança ou ultrapassa a vertical que passa na extremidade posterior da nadadeira adiposa 9

8'. Mancha do pedúnculo caudal, quando presente, comparativamente curta e larga, estendendo-se principalmente na base dos raios da nadadeira caudal, raramente até o final dos raios medianos; seu limite anterior não alcança a vertical que passa pela extremidade posterior da nadadeira adiposa

10

9. Olho grande, seu diâmetro de $39,8-44,4 \%$ do comprimento da cabeça; comprimento da cabeça de 24,2-27,0\% do comprimento padrão (drenagem do Rio Oiapoque, Guiana Francesa) ........................................... P. wayampi sp. nov.

$9^{\prime}$. Olho pequeno, seu diâmetro de $33,0-36,9 \%$ do comprimento da cabeça; comprimento da cabeça de 26,7-30,3 do comprimento padrão (sistema do Rio Xingu)

P. ojitatus sp. nov.

10. Mancha do pedúnculo caudal ausente; mancha umeral estendendo-se sobre a metade superior da escama da linha lateral; maxilar grande, 29,3-35,0\% do comprimento da cabeça (sistema do Rio Negro, Canal Casiaquiare e alto Rio Orinoco) P. prolatus sp. nov.

10'. Mancha do pedúnculo caudal presente; mancha umeral situada acima ou, no máximo, levemente sobre uma pequena parte superior da escama da linha lateral; maxilar pequeno, 21,3-30,8\% do comprimento da cabeça ........ 11

11. Mancha umeral verticalmente alongada, a metade superior 
difusa com cromatóforos mais esparsos; situada desde a região imediatamente à frente da segunda costela até a metade entre a quarta e a quinta costela, contadas a partir do final do pseudotímpano (drenagem do Rio Cuyuni, sistema do Rio Essequibo e baixo Rio Orinoco)

P. maculoblongus sp. nov.

11'. Mancha umeral nunca semelhante à acima; ovalada horizontalmente, arredondada, semicircular ou levemente vertical; quando levemente vertical, situada desde a primeira até a terceira costela, contadas a partir do final do pseudotímpano

12. Fileira externa do pré-maxilar incompleta, dividida em uma região medial e uma região lateral; usualmente com 1-5 dentes totais (média $=3,4$ na população do Rio Parnaíba e 2,8 nas demais drenagens); um dente na região medial, raramente dois (sistema do Rio Parnaíba e desde o Rio Curu ao Rio Piranhas, nordeste do Brasil) P. calverti

12 '. Fileira externa do pré-maxilar completa ou incompleta, com 4-11 dentes totais, raramente 3. Quando incompleta, dividida em uma região medial e uma região lateral, com 4-7 dentes totais, raramente três (média variando conforme a espécie, de cinco até 6,4 ); dois ou três dentes na região medial, raramente um; quando três dentes totais, com dois ou três dentes na região medial 13

13. Corpo baixo, maior altura de $25,1-31,8 \%$ do comprimento padrão (média $=28,9$ ). Ganchos presentes nas nadadeiras anal, pélvicas e peitorais dos machos .. 14

13'. Corpo comparativamente alto, maior altura de 29,2-40,1\% no comprimento padrão (média variando, conforme a espécie, de 33,4-33,9\%). Ganchos presentes nas nadadeiras pélvicas e anal dos machos, ausentes nas peitorais ...... 15

14. Espaço entre a margem inferior do terceiro infra-orbital e a margem horizontal do pré-opérculo relativamente grande (medida feita aproximadamente na metade do osso), cabendo de 4,9-6,5 vezes no diâmetro horizontal da órbita (drenagem do Rio Potaro, sistema do Rio Essequibo) ........

P. simulatus sp. nov.

14'. Espaço entre a margem inferior do terceiro infra-orbital e a margem horizontal do pré-opérculo usualmente pequena, cabendo de 7,4-10 vezes no diâmetro horizontal da órbita (sistemas dos rios Negro, Madeira e Xingu).

$P$. retropinnus sp. nov.

15. Terceiro infra-orbital comparativamente grande, sua margem ventral separada da margem horizontal do préopérculo usualmente por um espaço de $1 / 6$ a $1 / 8$, no máximo 1/11 do seu comprimento (sistema do Rio Corantijn, Suriname ao Rio Approuague, Guiana Francesa) P. wayana sp. nov.

$15^{\prime}$. Terceiro infra-orbital comparativamente pequeno, sua margem ventral separada da margem horizontal do pré-opérculo por um espaço de $1 / 3$ a $1 / 5$ do seu comprimento ... 16
16. Mancha umeral não-contornada por uma área clara; 37-38 (média $=37,4$ ) escamas perfuradas na série longitudinal; margem ventral do terceiro infra-orbital separada da margem horizontal do pré-opérculo por um espaço de 1/3 a 1/4 do seu comprimento, raramente $1 / 5$ (alto Rio Paraguai)

P. jancupa

16'. Mancha umeral contornada por uma área clara; 34-37 (média 35,7 ) escamas perfuradas na série longitudinal; margem ventral do terceiro infra-orbital separada da margem horizontal do pré-opérculo por um espaço de $1 / 4$ a 1/5 do seu comprimento (sistemas dos rios São Francisco e Paraguaçu) P. franciscoensis

\section{Phenacogaster capitulatus sp. nov.}

\section{Fig. 2}

Diagnose. Phenacogaster capitulatus distingue-se pelo menor comprimento da cabeça $(21,5-23,2 \%$ vs $23,3-29,3 \%$ do CP nas demais espécies, exceto em $P$. napoatilis e no complexo $P$. pectinatus). Difere de $P$. napoatilis pelo menor comprimento do focinho (4,3-5,3\% vs 5, 1-7,0\% do CP) e maior altura do corpo $(36,0-39,4 \%$ vs 31,6-36,9\% do CP em espécimes acima de $35,0 \mathrm{~mm}$ de $\mathrm{CP}$ ), e do complexo $P$. pectinatus por apresentar linha lateral incompleta ( $v s$ completa).

Descrição. Dados morfométricos na tabela I. Corpo comprimido, perfil dorsal convexo do focinho até o final da região interorbital, tornando-se côncavo até a base do processo supra-occipital, elevando-se e tornando-se acentuadamente convexo até a origem da nadadeira dorsal; inclinando-se para baixo e tornando-se reto desde a origem da nadadeira dorsal até o final do pedúnculo caudal; reto a levemente convexo ao longo da base da nadadeira dorsal. Perfil ventral do corpo acentuadamente convexo da extremidade da mandíbula até a origem da nadadeira anal, elevando-se e tornando-se reto a levemente convexo ao longo da base da nadadeira anal e reto no pedúnculo caudal. Focinho curto. Extremidade da maxila superior situase no mesmo nível ou ultrapassa levemente a ponta da mandíbula. Boca situada abaixo da linha mediana horizontal da órbita. Terceiro infra-orbital relativamente pequeno, sua margem ventral separada da margem horizontal do pré-opérculo por um espaço de 1/4 a 1/7 do seu comprimento; margem posterior contatando ou quase contatando a margem vertical do préopérculo. Duas fileiras de dentes no pré-maxilar; fileira externa completa ou incompleta, com 4-9 dentes totais (cinco do lado esquerdo e sete do lado direito no holótipo, média $=5,9 ; \mathrm{n}=$ 13). Quando contínua, possui 5-9 dentes que decrescem em tamanho, os dois ou três primeiros tricúspides maiores seguidos de dentes mais estreitos cônicos ou com pequeníssimas cúspides. Quando interrompida, possui dois dentes tricúspides na região medial e 2-5 dentes cônicos ou com pequeníssimas cúspides na região lateral, os da região medial maiores e mais largos que os demais. Fileira interna com 7-10 dentes (oito no holótipo, média $=8,1 ; \mathrm{n}=11$ ) que decrescem de tamanho, tor- 


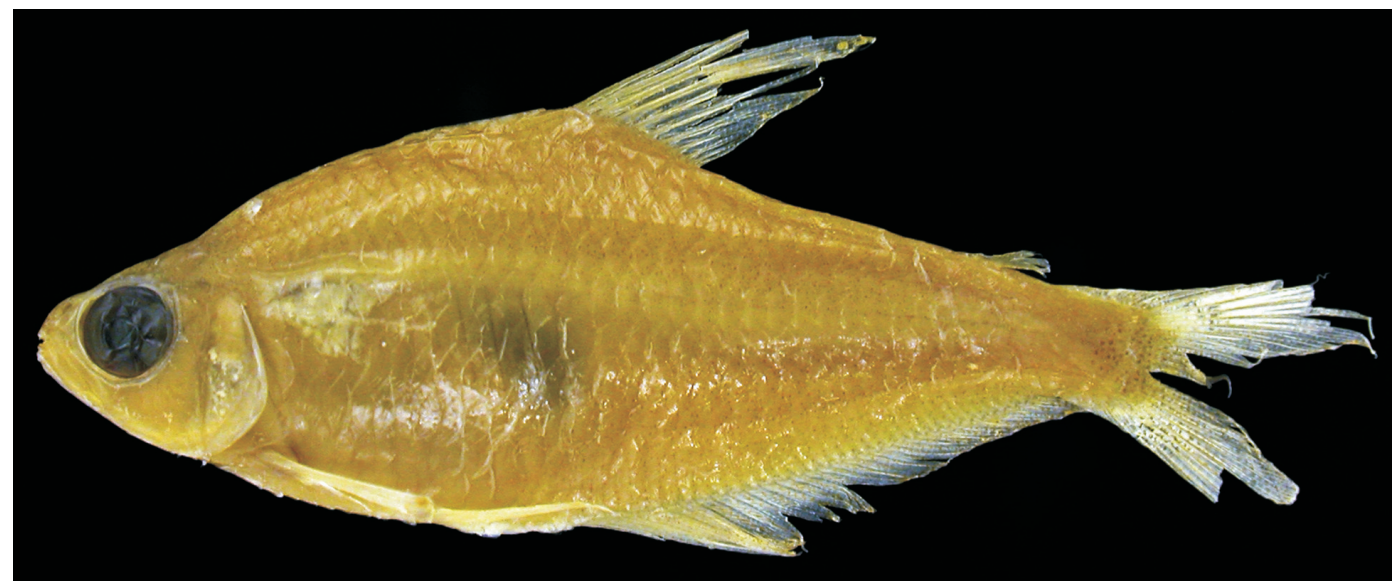

Figura 2. Phenacogaster capitulatus sp. nov., MUSM 20424, holótipo, 38,7 mm CP, afluente do Rio Neshuya, Peru.

Tabela I. Medidas de P. capitulatus sp. nov., holótipo MUSM 20424. (n) Número de exemplares, incluindo o holótipo.

\begin{tabular}{|c|c|c|c|c|c|}
\hline \multirow{2}{*}{ Medidas } & \multirow{2}{*}{ Holótipo } & \multicolumn{4}{|c|}{ Limites } \\
\hline & & $\mathrm{n}$ & Mínimo & Máximo & Média \\
\hline Comprimento padrão (mm) & 38,7 & 15 & 29,9 & 41,3 & 37,0 \\
\hline \multicolumn{6}{|c|}{ Porcentagens do comprimento padrão } \\
\hline Altura do corpo & 28,9 & 15 & 34,1 & 39,4 & 37,5 \\
\hline Comprimento pré-dorsal & 48,3 & 15 & 45,5 & 49,9 & 47,7 \\
\hline Comprimento pré-ventral & 34,6 & 15 & 34,1 & 35,9 & 35,2 \\
\hline Comprimento pré-anal & 48,8 & 15 & 46,5 & 52,6 & 49,2 \\
\hline Comprimento ped. caudal & 9,6 & 15 & 8,7 & 9,9 & 9,3 \\
\hline Altura ped. caudal & 9,6 & 15 & 8,0 & 9,9 & 9,2 \\
\hline Comprimento nad. peitoral & 18,3 & 15 & 18,9 & 21,7 & 19,9 \\
\hline Comprimento nad. pélvica & 17,8 & 15 & 16,5 & 18,7 & 17,3 \\
\hline Distância peitoral-pélvica & 12,1 & 15 & 10,4 & 13,2 & 11,8 \\
\hline Distância pélvica-anal & 11,4 & 15 & 10,0 & 12,8 & 11,6 \\
\hline Dist. occipital-dorsal & 27,9 & 15 & 26,1 & 31,0 & 28,3 \\
\hline Distância dorsal-adiposa & 26,8 & 15 & 28,0 & 31,3 & 29,7 \\
\hline Comprimento cabeça & 21,7 & 15 & 21,5 & 24,4 & 22,3 \\
\hline Comprimento focinho & 5,2 & 15 & 4,3 & 5,3 & 4,9 \\
\hline Comprimento maxilar & 5,9 & 15 & 5,8 & 6,7 & 6,2 \\
\hline Espaço interorbital & 7,0 & 15 & 6,6 & 7,2 & 6,9 \\
\hline Diâmetro órbita & 9,3 & 15 & 8,5 & 10,4 & 9,3 \\
\hline \multicolumn{6}{|c|}{ Porcentagens do comprimento da cabeça } \\
\hline Comprimento focinho & 23,8 & 15 & 19,2 & 24,1 & 21,8 \\
\hline Diâmetro órbita & 42,8 & 15 & 39,3 & 44,3 & 41,8 \\
\hline Comprimento maxilar & 27,4 & 15 & 26,0 & 30,9 & 27,7 \\
\hline Espaço interorbital & 32,1 & 15 & 28,8 & 32,6 & 31,1 \\
\hline
\end{tabular}


nando-se mais estreitos posteriormente, com pequeníssimas cúspides ou cônicos. Alguns espécimes possuem um dente localizado entre as fileiras externa e interna. Maxilar com 22-28 dentes cônicos (22 no holótipo, média $=24,9$; $\mathrm{n}=14$ ) dispostos ao longo de quase todo o seu comprimento. Dentário com 14-17 dentes dispostos em uma única fileira, os cinco ou seis primeiros tricúspides, maiores, seguidos de 9-12 menores e mais estreitos (cônicos visualizados no parátipo d\&c). Nadadeira dorsal com ii,9 raios (oito em um parátipo). Origem da nadadeira dorsal localizada próxima à metade do corpo. Nadadeira anal com iii,33-36 raios (34 no holótipo, iv no parátipo d\&c, média $=34,1 ; n=15)$. Origem da nadadeira anal localizada na vertical que passa pela base do segundo raio da nadadeira dorsal. Margem anterior da nadadeira anal levemente côncava, com o último raio não-ramificado e os cinco primeiros maiores que os demais; os três primeiros aproximadamente do mesmo tamanho; nos machos, os raios são mais desenvolvidos e a margem anterior é mais levemente côncava, quase retilínea; uma bainha de 11 escamas ao longo da base do primeiro ao décimo raio ramificado. Nadadeiras peitorais com 11-13 raios (12 no holótipo média $=12,4 ; \mathrm{n}=14$ ). Extremidade posterior do raio mais longo ultrapassa a origem das nadadeiras pélvicas, não atingindo a metade das nadadeiras pélvicas. Margem posterior do cleitro com leve ou forte reentrância ou com ondulação. Nadadeiras pélvicas, com i,7 raios, ultrapassam a origem da nadadeira anal, atingindo o primeiro raio e, no máximo, o segundo raio ramificado. Linha lateral incompleta, com 8-15 escamas perfuradas (oito no holótipo, média $=10,1 ; \mathrm{n}=15$ ). Seis fileiras de escamas entre a origem da nadadeira dorsal e a linha lateral. Quatro a cinco fileiras (cinco no holótipo, média $=4,7$; $\mathrm{n}=15$ ) entre a origem da nadadeira anal e a linha lateral. Uma escama pode estar ou não situada entre 1-3 pares de escamas ventrais, localizadas entre as origens das nadadeiras peitorais e pélvicas. Ramo superior do primeiro arco branquial com 4-5 rastros (cinco no holótipo média $=4,5 ; \mathrm{n}=15$ ) e ramo inferior com 7-9 rastros (nove no holótipo, média $=8,6 ; \mathrm{n}=15$ ). Vértebras totais 36, pré-caudais 15 e caudais 21 . Quatro supraneurais.

Coloração em álcool. A coloração do corpo é amarela. Região laterodorsal com pigmentos dispostos principalmente na borda das escamas. Região lateroventral com pigmentos dispostos em "V", com vértice voltado para a cauda e demarcando os mioseptos, entre as escamas da linha lateral e a nadadeira anal. Imediatamente acima da nadadeira anal, os cromatóforos situam-se obliquamente em relação ao eixo horizontal do corpo, entre as bases dos raios da nadadeira; região entre as axilas das nadadeiras peitorais e a metade entre as nadadeiras pélvicas e anal sem pigmentos. Opérculo com pigmentos restritos na região superior. Região dorsal da cabeça e dorso do corpo tão pigmentados quanto o restante do corpo. Mancha umeral presente em espécimes fêmeas e ausente em machos; inconspícua, oblíqua, situada acima da sétima à oitava escama da linha lateral e geralmente desde a terceira até a quarta costela, raramente até a quinta (da segunda a quarta em um parátipo), contada a partir do pseudotímpano. Seu comprimento horizontal é menor que a metade do diâmetro horizontal. Uma faixa clara despigmentada, situada na região médio-lateral, estende-se desde a região posterior do pseudotímpano até o pedúnculo caudal; essa faixa torna-se larga na vertical que passa aproximadamente pela metade da nadadeira dorsal. Pedúnculo caudal com uma mancha triangular, estendendo-se além da base da nadadeira caudal. Nadadeira caudal uniformemente pigmentada, geralmente com pigmentos maiores e mais concentrados entre os raios medianos. Nadadeira dorsal com pigmentos dispostos sobre as membranas inter-radiais até aproximadamente o sétimo raio ramificado; pigmentos restritos à margem posterior dos raios deste ponto até o último raio. Primeiro raio mais pigmentado que os demais. Nadadeiras pélvicas e peitorais relativamente claras, com pigmentos dispostos ao longo das margens dos raios; raios mais posteriores sem pigmentação. Nadadeira anal totalmente pigmentada. Nadadeira adiposa contornada por pigmentos.

Dimorfismo sexual. Foram examinados sete machos com 29,9-41,3 mm de CP. Espécimes machos não possuem mancha umeral e apresentam ganchos nos raios das nadadeiras peitorais, pélvicas e anal. Nadadeiras peitorais com ganchos retrorsos ao longo da região médio-dorsal do primeiro ao oitavo raio ramificado, um gancho por segmento. Nadadeiras pélvicas com raios dispostos na região lateral da porção distal do ramo mais externo, principalmente no segundo e terceiro raios ramificados (visualizados somente no parátipo d\&c). Ganchos na nadadeira anal pequeníssimos e em pequeno número, situados na região lateroposterior do ramo posterior, no primeiro, e do quarto ao oitavo raios ramificados; um gancho por segmento; ganchos pequeníssimos presentes também na região lateroanterior do ramo anterior, do primeiro ao sexto raios ramificados.

Material examinado. Holótipo macho. Peru, Ucayali: Rio Neshuya (sistema do Rio Ucayali, Coronel Portillo) 15/IX/1983, J. Cánepa leg., MUSM 20424 (38,7 mm CP). Parátipos: Peru, Ucayali: Rio Neshuya, (sistema do Rio Ucayali, Coronel Portillo), 15/IX/1983, J. Cánepa leg., coletados juntamente com o holótipo, MCP 43595 (3, 37,0-39,6 mm CP, 1 ex. (cabeça metalizada para exame em MEV) MUSM 0886 (11, 29,9-41,3 $\mathrm{mm} \mathrm{CP}, 1$ d\&c 35,8 mm CP).

Distribuição. Conhecida somente da localidade-tipo, Rio Neshuya, sistema do Rio Ucayali, Peru (Fig. 3).

Etimologia. Do latim capitulum, cabeça pequena; atus, posse.

\section{Phenacogaster maculoblongus sp. nov.}

\section{Fig. 4}

Diagnose. A presença de uma grande mancha umeral conspícua e verticalmente alongada em machos e fêmeas distingue P. maculoblongus da maioria das espécies de Phenacogaster, exceto de $P$. prolatus e $P$. ojitatus. Nas demais espécies, a mancha, quando grande e conspícua, possui forma arredondada ou horizontalmente ovalada. Diferencia-se de $P$. prolatus pela man- 


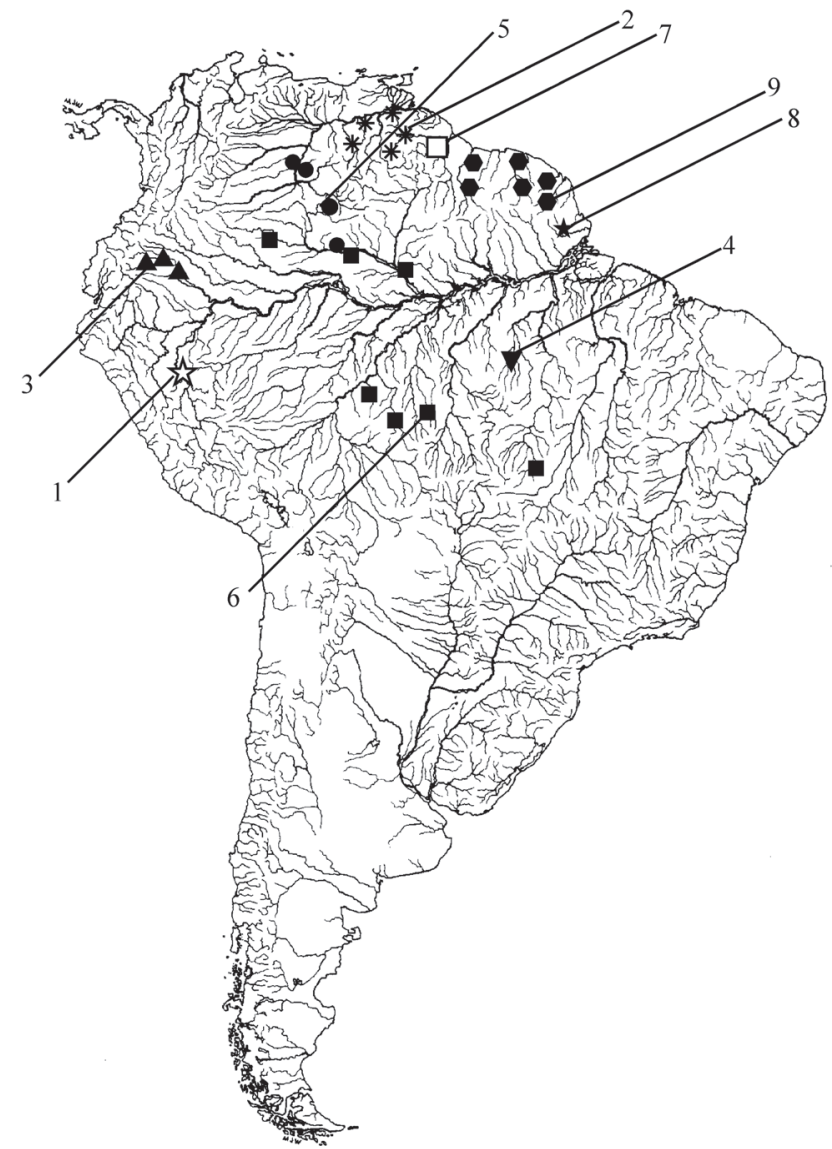

Figura 3. Distribuição de Phenacogaster capitulatus (estrela branca, 1), P. maculoblongus (asterisco, 2), P. napoatilis (triângulo, 3), P. ojitatus (triângulo invertido, 4), P. prolatus (ponto, 5), P. retropinnus (quadrado preto, 6), P. simulatus (quadrado branco, 7), P. wayampi (estrela, 8) e $P$. wayana (hexágono, 9). Números indicam as localidades-tipo.

cha umeral não se estender sobre as escamas da linha lateral ( $v s$ sobre as escamas da linha lateral), presença de mancha conspícua no pedúnculo caudal ( $v s$ ausência), menor número de raios ramificados na nadadeira anal (28-34, média $=32,0$ vs 33 38 média $=35,4)$, maior espaço interorbital $(24,2-29,3 \%$ vs 20,2$25,0 \%$ no CC), menor comprimento do maxilar $(22,5-28,7 \%$ vs 29,3-35\% no CC). Difere de P. ojitatus pelo maior diâmetro orbital $(37,8-47,1 \%$ vs 33,0-36,9\% no CC). Duas outras espécies que também possuem mancha umeral relativamente grande e conspícua são simpátricas com $P$. maculoblongus: $P$. megalostictus e $P$. simulatus. Difere adicionalmente de $P$. megalostictus por apresentar linha lateral com 36-39 (média = 37,5 ) escamas perfuradas ( vs 33-37, média $=35$ ), primeira série de dentes do pré-maxilar interrompida ( $v s$ completa), maior número de dentes no maxilar (19-30, média $=23,9$ vs 9-21, média $=16,0)$, menor comprimento do maxilar $(5,9-7,3 \%$ vs $7,1-8,7 \%$ do CP), menor comprimento da cabeça em espécimes acima de $30,0 \mathrm{~mm}$ de CP $(23,6-26,8 \%$ vs $25,3-29,2 \%$ do $\mathrm{CP})$ e em espécimes abaixo de $30,0 \mathrm{~mm}$ de CP $(24,3-27,5 \%$ vs $28,5-31,7 \%$ do CP), menor diâmetro orbital (9,3-11,8\% vs 10,5$14,4 \%$ do $\mathrm{CP}$ ), e presença de pequeníssimos ganchos na parte distal dos raios ramificados das nadadeiras anal e pélvicas (vs ausentes). De $P$. simulatus, além da forma da mancha umeral (vertical $v s$ circular ou semicircular), difere pelo maior espaço interorbital em espécimes machos maiores de $30 \mathrm{~mm}$ de CP (24,7-29,3\% vs 22,0-25,7\% CC, ).

Descrição. Dados morfométricos na tabela II. Corpo comprimido, perfil dorsal convexo do focinho ao final da região interorbital, elevando-se e continuando reto ou levemente côncavo até a base do processo supra-occipital; convexo da base do processo supra-occipital até a origem da nadadeira dorsal; declinando-se e tornando-se reto da origem da nadadeira dorsal ao fim do pedúnculo caudal; algumas vezes convexo ao longo da base da nadadeira dorsal. Perfil ventral do corpo levemente convexo da extremidade da mandíbula até a origem da nadadeira anal, quase retilíneo entre as origens das nadadeiras peitorais e anal em alguns indivíduos; elevando-se e tornando-se reto ao longo da base da nadadeira anal e reto ou levemente côncavo no pedúnculo caudal. Extremidade da maxila superior no mesmo nível da ponta da mandíbula ou ultrapassando levemente a acentuadamente a ponta da mandíbula. Boca situada aproximadamente na linha mediana horizontal da órbita ou abaixo. Margem ventral do terceiro infra-orbital separada da margem horizontal do pré-opérculo por um espaço de $1 / 5$ a 1/7 (1/3 do lado esquerdo de um único espécime do lote UF 96216), podendo chegar até a $1 / 9$ do seu comprimento; margem posterior separada da margem vertical do pré-opérculo por um espaço um pouco menor, podendo contatá-la. Duas fileiras de dentes no pré-maxilar; fileira externa interrompida, com 37 dentes totais (seis no holótipo, média $=4,8 ; \mathrm{n}=56$ ), geralmente dois tricúspides, raramente um, três ou quatro, na região medial, maiores que os da região lateral e 1-4 dentes, geralmente dois ou três, cônicos ou com pequeníssimas cúspides, mais delgados, na região lateral. Fileira interna com 8-10 dentes (oito no holótipo, média $=9,1 ; \mathrm{n}=56$ ), geralmente os três primeiros tricúspides maiores e mais largos que os demais, seguidos de dentes tricúspides e cônicos mais delgados (sete tricúspides seguidos de um cônico, contado em um parátipo clarificado e corado). Alguns espécimes possuem um dente cônico localizado na porção posterior do pré-maxilar, entre as fileiras externa e interna. Maxilar com 20-30 dentes cônicos (23 no holótipo, média $=23,9 \mathrm{n}=58$ ) situados ao longo de quase toda a margem ventral. Dentário com 13-17 dentes em uma única fileira, os cinco ou seis primeiros tricúspides, seguidos de dentes cônicos menores ou gradualmente menores e mais delgados. Nadadeira dorsal com ii,9 raios (10 em um parátipo). Origem da nadadeira dorsal localizada próxima à metade do corpo. Nadadeira anal com iii-iv,30-34 raios (32 no 


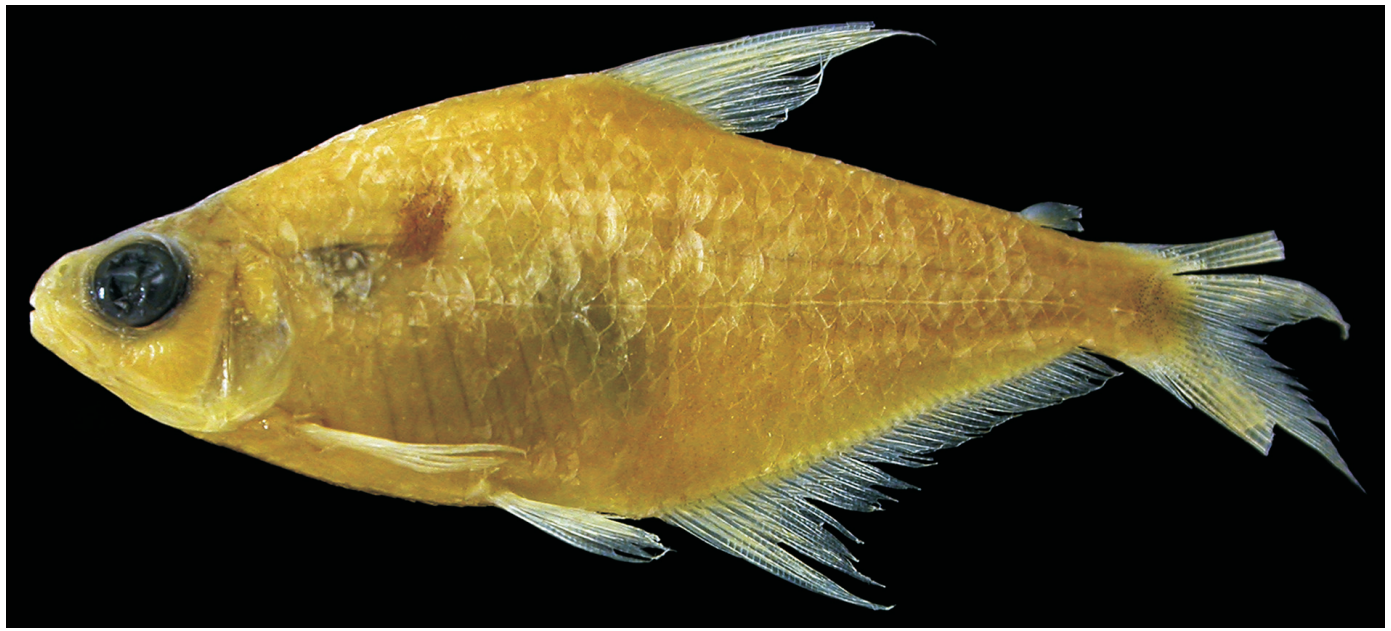

Figura 4. Phenacogaster maculoblongus sp. nov., MBUCV-V-30230, holótipo, 45,4 mm CP, caño Caballepe, Venezuela.

Tabela II. Medidas de P. maculoblongus sp. nov., holótipo MBUCV-V-30230. (n) Número de exemplares, incluindo o holótipo.

\begin{tabular}{|c|c|c|c|c|c|}
\hline \multirow{2}{*}{ Medidas } & \multirow{2}{*}{ Holótipo } & \multicolumn{4}{|c|}{ Limites } \\
\hline & & $\mathrm{n}$ & Mínimo & Máximo & Média \\
\hline Comprimento padrão (mm) & 45,4 & 48 & 24,5 & 45,4 & 33,9 \\
\hline \multicolumn{6}{|c|}{ Porcentagens do comprimento padrão } \\
\hline Altura do corpo & 36,8 & 48 & 28,5 & 37,7 & 31,9 \\
\hline Comprimento pré-dorsal & 50,9 & 48 & 46,7 & 52,2 & 49,3 \\
\hline Comprimento pré-ventral & 39,7 & 47 & 36,2 & 40,8 & 38,7 \\
\hline Comprimento pré-anal & 53,5 & 48 & 49,6 & 57,0 & 53,3 \\
\hline Comprimento ped. caudal & 8,8 & 47 & 7,5 & 10,8 & 9,2 \\
\hline Altura ped. caudal & 9,0 & 48 & 7,4 & 9,7 & 8,4 \\
\hline Comprimento nad. peitoral & 22,5 & 27 & 19,6 & 24,2 & 22,1 \\
\hline Comprimento nad. pélvica & 17,0 & 31 & 16,1 & 19,1 & 17,6 \\
\hline Distância peitoral-pélvica & 14,1 & 30 & 10,1 & 14,5 & 12,0 \\
\hline Distância pélvica-anal & 12,1 & 31 & 9,4 & 14,2 & 11,5 \\
\hline Dist. occipital-dorsal & 28,6 & 31 & 24,4 & 28,6 & 26,0 \\
\hline Distância dorsal-adiposa & 28,6 & 31 & 25,9 & 30,7 & 28,1 \\
\hline Comprimento cabeça & 23,8 & 48 & 23,6 & 27,5 & 25,5 \\
\hline Comprimento focinho & 6,6 & 48 & 4,9 & 7,8 & 6,4 \\
\hline Comprimento maxilar & 6,4 & 48 & 5,9 & 7,3 & 6,5 \\
\hline Espaço interorbital & 6,2 & 48 & 6,0 & 7,6 & 6,7 \\
\hline Diâmetro órbita & 9,9 & 48 & 9,3 & 11,8 & 10,7 \\
\hline \multicolumn{6}{|c|}{ Porcentagens do comprimento da cabeça } \\
\hline Comprimento focinho & 27,8 & 48 & 19,5 & 29,5 & 25,0 \\
\hline Diâmetro órbita & 41,7 & 48 & 37,8 & 47,1 & 41,9 \\
\hline Comprimento maxilar & 26,8 & 48 & 22,5 & 28,7 & 25,5 \\
\hline Espaço interorbital & 25,9 & 48 & 24,2 & 29,3 & 26,6 \\
\hline
\end{tabular}


holótipo, cinco raios não-ramificados em dois parátipos diafanizados e corados, média $=32 ; \mathrm{n}=93$ ). Origem da nadadeira anal localizada aproximadamente na vertical que passa pela base do quarto ao sexto raio ramificado da nadadeira dorsal. Porção anterior da nadadeira anal levemente côncava, com o último raio não-ramificado e os seis primeiros raios ramificados maiores que os demais (os três primeiros aproximadamente do mesmo tamanho); raios geralmente mais desenvolvidos nos machos; uma bainha de, aproximadamente, 7-10 escamas ao longo da base do primeiro raio não-ramificado até, no máximo, o décimo raio ramificado. Nadadeiras peitorais com i,1115 raios (13 no holótipo, 15 em um único parátipo, média = 12,$3 ; \mathrm{n}=94$ ), extremidade posterior do raio mais longo ultrapassa a origem das nadadeiras pélvicas, não alcançando ou ultrapassando levemente a metade dessas nadadeiras; raios totalmente desenvolvidos nos indivíduos examinados. Margem posterior do cleitro geralmente sem ou raramente com reentrância. Nadadeiras pélvicas, com i,7 raios (um parátipo com seis), ultrapassam a origem da nadadeira anal, atingindo geralmente o primeiro ou o segundo raio ramificado dessa nadadeira. Linha lateral com 37-39 escamas perfuradas (39 no holótipo, média $=37,5 \mathrm{n}=31$ ). Seis (seis no holótipo, cinco em um e sete em dois parátipos) fileiras de escamas entre a origem da nadadeira dorsal e a linha lateral; cinco fileiras (cinco no holótipo, um parátipo com quatro) entre a linha lateral e a origem da nadadeira anal. Ausência ou presença de uma única escama sobreposta entre 1-7 pares de escamas pré-ventrais, localizadas entre as origens das nadadeiras peitorais e pélvicas. Ramo superior do primeiro arco branquial com 4-6 rastros (seis no holótipo, média $=5 ; \mathrm{n}=84$ ) e ramo inferior com 8-10 rastros (nove no holótipo, média $=9 ; \mathrm{n}=84$ ). Vértebras totais 35 37 em cinco parátipos diafanizados e corados: pré-caudais 15 e caudais 21 (dois), pré-caudais 16 e caudais 21 (um), pré-caudais 15 e caudais 20 (dois). Quatro a cinco supraneurais em três e dois parátipos, respectivamente.

Coloração em álcool. A coloração geral do corpo é amarela. Região laterodorsal com cromatóforos castanhos dispostos na borda das escamas, principalmente próximos ao dorso, e distribuídos homogeneamente mais abaixo. Região lateroventral, entre as nadadeiras peitorais e a origem da nadadeira anal, algumas vezes menos pigmentada ou totalmente desprovida de pigmentação. Na região entre a linha lateral e a nadadeira anal, os cromatóforos estão espalhados uniformemente sobre as escamas e/ou dispõem-se em forma de $>$, demarcando os mioseptos. Opérculo quase totalmente pigmentado, com pigmentos estendendo-se além da metade do osso (com poucos pigmentos no holótipo); algumas vezes a pigmentação é restrita à região superior. Região dorsal da cabeça e dorso do corpo mais intensamente pigmentados em relação ao restante do corpo. Mancha umeral conspícua - com a região superior mais difusa - e verticalmente alongada, levemente oblíqua, situada acima da sexta à sétima ou oitava escamas da linha lateral, podendo se estender levemente sobre pe- quena parte superior de uma ou duas escamas da linha lateral; situa-se, geralmente, desde a região imediatamente anterior à segunda costela, na sua parte ventral, até a metade entre a quarta e a quinta costela, contada a partir do pseudotímpano, na sua parte dorsal. Seu comprimento horizontal é geralmente menor ou igual à metade do diâmetro orbital, mas pode ser maior (lote UF 96216). Uma linha escura, na região médio-lateral do corpo, acima da linha lateral, se estende desde a região posterior da mancha umeral até a mancha do pedúnculo caudal, tornando-se mais conspícua a partir da vertical que passa pela origem da nadadeira dorsal. Algumas vezes, imediatamente abaixo dessa linha, estende-se uma faixa quase desprovida de pigmentação. Presença de uma conspícua mancha triangular, no pedúnculo caudal, que se prolonga geralmente além da porção basal dos raios da nadadeira caudal, mas, em geral, não se estende até o final dos raios medianos. Na nadadeira caudal, a mancha pode ser ou não contornada por uma região clara. Nadadeira caudal com pigmentos esparsos, algumas vezes com pigmentos mais concentrados na porção mais distal dos raios. Nadadeira dorsal com pigmentos ao longo das margens anterior e posterior das membranas inter-radiais, sem pigmentos ou menos pigmentada, com cromatóforos menores na região basal; primeiro raio não-ramificado da nadadeira dorsal pigmentado. Nadadeiras peitorais e pélvicas claras, levemente pigmentadas ao longo das margens anterior e posterior das membranas interradiais. Nadadeira anal com a base e a extremidade dos raios mais escuros, de modo a formar, na região mediana da nadadeira, uma faixa clara ou com pigmentos mais claros aproximadamente a partir do sétimo raio ramificado.

Dimorfismo sexual. Foram examinados machos com 27,9 a 39,3 mm de CP (MBUCV-V 26501, MBUCV-V 10110, MBUCVV 10206, lotes MCP 26496, MCP 26497, UF 96216, UF 96207). Apresentam ganchos nos raios das nadadeiras peitorais, pélvicas e anal. Nadadeira anal com ganchos que podem estar situados desde o último raio não-ramificado até o $13^{0}$ raio ramificado, dispostos lateroposteriormente no segundo ramo, raramente, também no primeiro; um ou dois ganchos por segmento. Pequeníssimos ganchos na porção distal dos raios ramificados da nadadeira anal, dispostos anteriormente no ramo anterior e também no ramo posterior são visualizados somente em espécimes diafanizados e corados. Nadadeiras pélvicas com ganchos retrorsos, dispostos medialmente, ao longo do primeiro raio não-ramificado ou ramificado até penúltimo ou último raio ramificado, com um gancho, raramente dois, em cada segmento. Da mesma forma que na nadadeira anal, apresentam pequeníssimos ganchos na porção distal dos raios ramificados. Ganchos das nadadeiras peitorais diminutos, situados sobre a região medial ao longo da parte dorsal dos raios, geralmente ausentes em indivíduos menores que $30 \mathrm{~mm}$ de CP.

Material examinado. Holótipo. Venezuela, Bolivar: Caño Caballepe ( $1 \mathrm{~km}$ de Tumeremo, sistema do Rio Cuyuni, $07^{\circ} 17^{\prime} \mathrm{N}$ $61^{\circ} 30^{\prime}$ W), 28/I/1977, F. Mago Leccia et al. leg., MBUCV-V-30230 $(45,4 \mathrm{~mm} \mathrm{CP})$. 
Parátipos. Venezuela, Bolivar: Caño Caballepe $(1 \mathrm{~km}$ de Tumeremo, sistema do Rio Cuyuni, $\left.07^{\circ} 17^{\prime} \mathrm{N} 61^{\circ} 30^{\prime} \mathrm{W}\right), 28 / \mathrm{I} / 1977$, F. Mago Leccia et al. leg., coletados juntamente com o holótipo, MBUCV-V 10110 (14, 27,4-45,4 mm CP); Rio Cuyuni (Isla Jacobo próximo ao Raudal de Kinotovaca, $06^{\circ} 44^{\prime} \mathrm{N} 61^{\circ} 38^{\prime} \mathrm{W}$, coordenadas aproximadas), 26/I/1977, F. Mago Leccia \& A. Machado leg., MBUCV-V 10206 (100, 25,4-42,0 mm CP, 3 d\&c, 34,5-42,1 $\mathrm{mm} \mathrm{CP}$ ); Caño Curumito (tributário do Rio Botanamo, na estrada Tumeremo - Bochinche, sistema do Rio Cuyuni, $07^{\circ} 17^{\prime} \mathrm{N}$ $\left.61^{\circ} 30^{\prime} \mathrm{W}\right), 22 / \mathrm{I} / 1991$, F. Provenzano et al. leg., MBUCV-V 26417 (12, 24,1-38,3 mm CP); Caño Caballepe (1 km de Tumeremo, sistema do Rio Cuyuni, $\left.07^{\circ} 17^{\prime} \mathrm{N} 61^{\circ} 30^{\prime} \mathrm{W}\right), 28 / \mathrm{I} / 1977$, F. Mago Leccia et al. leg., coletados juntamente com o holótipo, MCP 26496 (6, 27,9-43,2 mm CP); Rio Cuyuni (Isla Jacobo próximo ao Raudal de Kinotovaca, $06^{\circ} 44^{\prime} \mathrm{N} 61^{\circ} 38^{\prime} \mathrm{W}$, coordenadas aproximadas), 26/I/1977, F. Mago Leccia \& A. Machado leg., MCP 26497 (13, 28,9-40,3 mm CP, 2 d\&c, 32,8-33,7 mm CP); Caño Curumito (tributário do Rio Botanamo, na estrada Tumeremo Bochinche, sistema do Rio Cuyuni, $\left.07^{\circ} 17^{\prime} \mathrm{N} 61^{\circ} 30^{\prime} \mathrm{W}\right), 22 / \mathrm{I} / 1991$, F. Provenzano et al. leg., MCP 26501 (4, 28,1-33,3 mm CP); Rio Parapapoy (tributário do Rio Supamo, sistema do Rio Cuyuni, Roscio, $\left.06^{\circ} 35^{\prime} \mathrm{N} 62^{\circ} 39^{\prime} \mathrm{W}\right), 27 / \mathrm{XI} / 1992$, Leo G. Nico \& Victor Munoz leg., UF 96189 (5, 24,5-40,5 mm CP); Rio Parapapoy (tributário do Rio Supamo, sistema do Rio Cuyuni, Roscio, $06^{\circ} 35^{\prime} \mathrm{N}$ $62^{\circ} 38^{\prime}$ W), 29/XI/1992, Leo G. Nico \& Victor Munoz leg., UF 96199 (3, 21,9-29,1 mm CP), Rio Parapapoy (tributário do Rio Supamo, sistema do Rio Cuyuni, Roscio, $06^{\circ} 35^{\prime} \mathrm{N} 62^{\circ} 38^{\prime} \mathrm{W}$ ), $29 /$ XI/1992, Leo G. Nico \& Victor Munoz leg., UF 96207 (4, 29,5$34,7 \mathrm{~mm} \mathrm{CP}$ ); riacho na floresta, tributário sul do Rio Parapapoy (sistema do Rio Cuyuni, Roscio, $06^{\circ} 35^{\prime} \mathrm{N} 62^{\circ} 38^{\prime} 30^{\prime \prime} \mathrm{W}$ ), 9/XII/ 1992, Leo G. Nico \& Victor Munoz leg., UF 96216 (5, 34,6-39,8 mm CP). Não-tipos. Venezuela, Anzoategui: rio costeiro, margem $\mathrm{N}$ do Rio Orinoco $\left(08^{\circ} 09^{\prime} 48^{\prime \prime} \mathrm{N} 63^{\circ} 31^{\prime} 24^{\prime \prime} \mathrm{W}\right), 8 / \mathrm{XI} / 1979$, ANSP 149478 (1, 30,5 mm CP), ANSP 149483 (2, 29,5-32,5 mm CP). Bolivar: Rio Mato, (afluente do Rio Caura, sistema do Rio Orinoco,

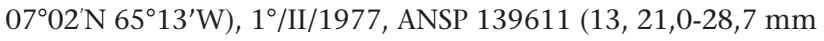
$\mathrm{CP}$ ); Rio Supamo (cerca de $30 \mathrm{~km}$ ao sul de El Yagual, sistema do Rio Cuyuni, $06^{\circ} 50^{\prime} \mathrm{N} 62^{\circ} 20^{\prime} \mathrm{W}$ ), 20/I/1991, ANSP 168086 (42, 14,6-35,6 mm CP, 3 d\&c, 27,6-35,6 mm CP); Caño Curumito (tributário do Rio Botanamo, na estrada Tumeremo - Bochinche, sistema do Rio Cuyuni, $\left.07^{\circ} 20^{\prime} \mathrm{N} 61^{\circ} 20^{\prime} \mathrm{W}\right), 22 / \mathrm{jan} / 1991$, ANSP 168087 (24, 17,6-36,6 mm CP, 1 d\&c, 34,5 mm CP); Rio Hacha (cerca de $10 \mathrm{Km}$ de El Yagual, (afluente do Rio Caura), sistema do Rio Orinoco), 20/I/1991, MBUCV-V 26799 (25, 14,5-30,0 mm $\mathrm{CP}$ ); Rio Hacha (cerca de $10 \mathrm{Km}$ de El Yagual, afluente do Rio Caura, sistema do Rio Orinoco), 20/I/1991, MCP 26502 (6, 17,5$34,7 \mathrm{~mm} \mathrm{CP}$ ); Islote de Fajardo (sistema do Rio Orinoco, $08^{\circ} 22^{\prime} \mathrm{N}$ $\left.62^{\circ} 42^{\prime} \mathrm{W}\right), 15 / \mathrm{II} / 1978$, USNM 233143 (2, 25,9-32,0 mm CP). Delta Amacuro: Caño Araguao (sistema do Rio Orinoco, $08^{\circ} 38^{\prime} \mathrm{N}$ $61^{\circ} 43^{\prime} \mathrm{W}$ ), 21/II/1978, USNM 233135 (2, 21,4-25,1 mm CP); pequeno rio próximo à foz do Caño Socoroco (sistema do Rio Orinoco, $\left.08^{\circ} 35^{\prime} \mathrm{N} 61^{\circ} 42^{\prime} \mathrm{W}\right), 20 / \mathrm{II} / 1978$, USNM 233136 (6, 24,9$34,9 \mathrm{~mm} \mathrm{CP})$.
Distribuição. Alto Rio Cuyuni, sistema do Rio Essequibo e baixo Rio Orinoco, Venezuela (Fig. 3).

Etimologia. Do latim macula, mancha; oblongus, comprimento maior do que a largura. Em alusão à mancha umeral reta, alongada, posicionada verticalmente.

Comentários. A população do sistema do Rio Cuyuni apresenta, geralmente, a boca terminal ou subterminal, com o focinho ultrapassando levemente a ponta da mandíbula, com exceção de alguns espécimes cujo focinho é mais proeminente e a boca está em posição mais ventral. A população do sistema do Rio Orinoco não apresentou variação, com a boca mais ventral do que na maioria dos espécimes do sistema do Rio Cuyuni. No entanto, não observamos características adicionais que permitam a diferenciação entre essas duas populações e, portanto, são consideradas uma única espécie. Um espécime não-tipo do lote ANSP 168086 apresentou dois dentes na região medial da fileira externa do pré-maxilar e nenhum na região lateral. Fileira interna do pré-maxilar com 5-8 dentes tricúspides seguidos de 2-4 cônicos em quatro espécimes não-tipos diafanizados e corados dos lotes ANSP 168086 e ANSP 168087. Maxilar com 19 dentes em um espécime não-tipo do lote ANSP 168087. Nadadeira anal com 28 e 29 raios ramificados em dois e cinco espécimes não-tipos, respectivamente. Espécimes não-tipos com raios das nadadeiras peitorais totalmente desenvolvidos em espécimes acima de $19 \mathrm{~mm}$ de CP e geralmente não desenvolvidos em espécimes abaixo desse comprimento; somente um único espécime não-tipo de $16,5 \mathrm{~mm}$ CP possui peitorais desenvolvidas. Linha lateral com 36 escamas perfuradas em um espécime não-tipo (ANSP 168087). Três rastros na região inferior do primeiro arco branquial em um espécime não-tipo (ANSP 168087). Em um espécime não-tipo do lote MCP 26502 os ganchos das nadadeiras pélvicas estendem-se somente até o antepenúltimo raio ramificado. Os parátipos MBUCV-V 10206 foram coletados em ambiente com água transparente, ácida, correnteza forte a muito forte, com rochas de grande tamanho e fundo de areia grossa e seixos (F. Provenzano com. pess.). No caño Curumito, onde foram amostrados os espécimes não-tipos ANSP 168087, a água é parada, sem correnteza, barrenta, com fundo lodoso. Parátipos do Rio Parapapoy foram coletados entre $20 \mathrm{~cm}$ a $2 \mathrm{~m}$ de profundidade, em área de mineração.

\section{Phenacogaster napoatilis sp. nov.}

$$
\text { Fig. } 5
$$

Diagnose. A presença de linha lateral incompleta diferencia $P$. napoatilis das demais espécies do gênero, exceto de $P$. capitulatus, $P$. carteri e $P$. tegatus. Diferencia-se de $P$. capitulatus por apresentar maior comprimento do focinho $(5,1-7,0 \% \mathrm{vs}$ $4,3-5,3 \%$ do CP) e menor altura do corpo (31,6-36,9\% do CP $v s$ 36,0-39,4 do comprimento padrão em espécimes maiores que 35, $0 \mathrm{~mm}$ de $\mathrm{CP})$.

Difere de $P$. carteri pela presença de mancha umeral em fêmeas ( $v s$ ausência). Diferencia-se, ainda, de $P$. carteri pela menor altura do pedúnculo caudal em machos (6,3-9,0\% vs 9,9\% 


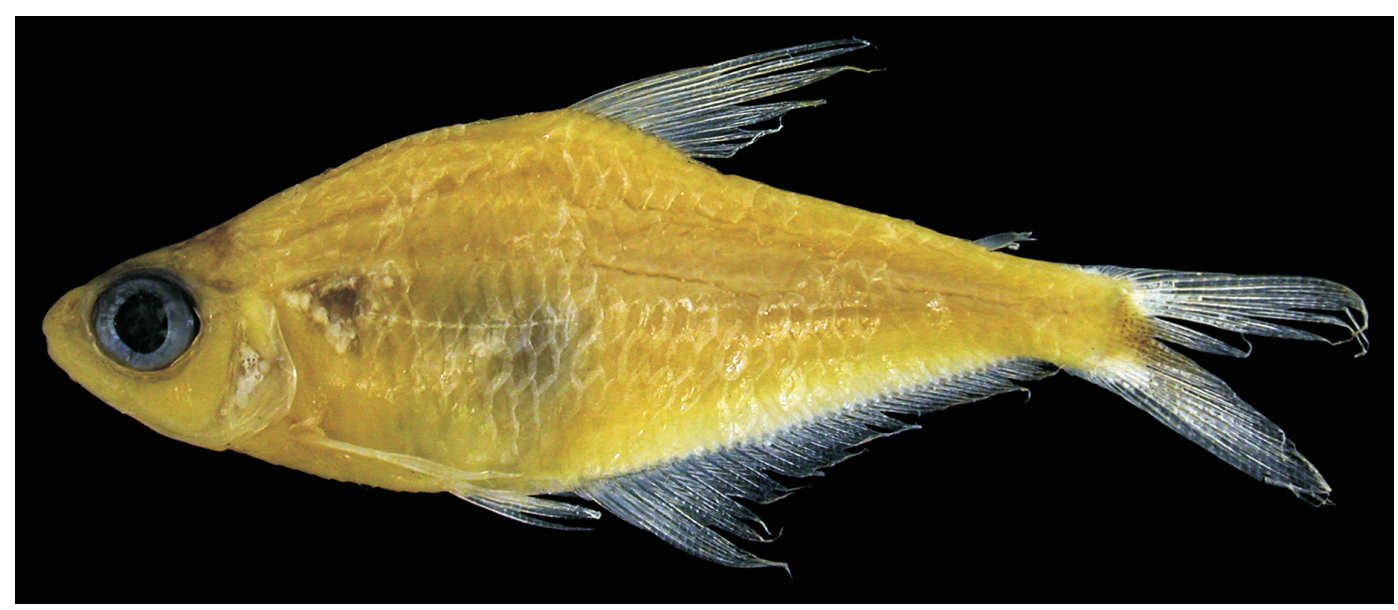

Figura 5. Phenacogaster napoatilis sp. nov., MCZ 51485, holótipo, 32,6 mm CP, Rio Napo e afluentes, Equador.

no único macho identificado de $P$. carteri) e pelo menor comprimento do maxilar em espécimes maiores que $30 \mathrm{~mm}$ de CP $(5,9$ 7,0\% vs 6,9-7,8\% no CP). De $P$. tegatus diferencia-se pela ausência de mancha umeral em machos e inconspícua mancha umeral próxima ao pseudotímpano, em fêmeas ( $v s$ mancha umeral conspícua e distante do pseudotímpano de P. tegatus).

Descrição. Dados morfométricos na tabela III. Corpo comprimido, perfil dorsal levemente convexo desde o focinho até o final do espaço interorbital, elevando-se e tornando-se reto ou côncavo até a base do processo supra-occipital e convexo deste ponto até a origem da nadadeira dorsal; declinando-se e tornando-se reto desde a origem da nadadeira dorsal até o fim do pedúnculo caudal, reto ou levemente convexo ao longo da margem da nadadeira dorsal e no pedúnculo caudal. Perfil ventral do corpo levemente convexo da extremidade da mandíbula até a origem das nadadeiras pélvicas e retilíneo deste ponto até a origem da nadadeira anal; elevando-se e continuando reto ou levemente convexo ao longo da base da nadadeira anal e reto ou levemente côncavo no pedúnculo caudal. Extremidade da maxila superior ultrapassa levemente a ponta da mandíbula. Boca situada abaixo da linha mediana horizontal da órbita. Margem ventral do terceiro infra-orbital separada da margem horizontal do pré-opérculo por um espaço de $1 / 5$ a $1 / 9$ do seu comprimento ( $1 / 4$ em indivíduos com cerca de $20,0 \mathrm{~mm}$ de CP); margem posterior contata ou quase contata a margem vertical do préopérculo, exceto em espécimes com cerca 20,0 mm de CP. Duas fileiras de dentes no maxilar, fileira externa interrompida ou contínua, com 4-10 dentes totais (sete no holótipo, média $=6,5$; $\mathrm{n}=24$ ); quando interrompida possui 4-7 dentes totais, sendo dois ou três tricúspides na região medial (três no holótipo), mais largos e geralmente maiores, seguidos de 1-5 cônicos, mais estreitos, na região lateral (quatro no holótipo); quando completa possui 6-10 dentes, os 2-3 tricúspides mais largos e maiores que os demais seguidos de dentes tricúspides e cônicos. Fileira interna com 5-12 dentes (oito no holótipo, média = 8,7; $\mathrm{n}=26$ ), sendo os três ou quatro primeiros tricúspides geralmente mais largos que os demais, seguidos de dentes tricúspides e cônicos mais estreitos, os últimos menores e mais delgados. Alguns espécimes possuem um dente cônico localizado na porção posterior do pré-maxilar, entre as fileiras externa e interna. Maxilar com 20-29 dentes cônicos ( 25 no holótipo, média $=25,1 ; \mathrm{n}=19$ ) situados ao longo de quase toda a sua margem ventral. Dentário com 12-18 dentes $(\mathrm{n}=24)$, os cinco ou seis primeiros tricúspides seguidos de dentes cônicos ou bicúspides menores e mais estreitos.Nadadeira dorsal com ii,9 raios. Origem da nadadeira dorsal localizada próxima à metade do corpo. Nadadeira anal com iii-iv,32-38 raios (33 no holótipo, média $=34,6 ; \mathrm{n}=36$ ). Origem da nadadeira anal localizada na vertical que passa pela base do primeiro ou segundo raio ramificado. Margem da nadadeira anal levemente côncava, com o último raio não-ramificado e os seis primeiros maiores que os demais, os três primeiros aproximadamente do mesmo tamanho; uma bainha de até pelo menos 10 escamas se estende ao longo da base da nadadeira anal do primeiro raio não-ramificado até o oitavo raio ramificado. Nadadeiras peitorais com i,11-16 raios (12 no holótipo, 16 em um único parátipo, média $=13,5 ; \mathrm{n}=31$ ), extremidade posterior do raio mais longo ultrapassa a origem das nadadeiras pélvicas, atingindo, aproximadamente, a metade dessas nadadeiras; raios não desenvolvidos em indivíduos de 21,5 e 21,7 $\mathrm{mm}$ de $\mathrm{CP}$, parcialmente desenvolvidos em indivíduos de 22,7 mm de CP. Indivíduos com 25,5 mm de CP possuem os raios das nadadeiras totalmente desenvolvidos. Margem posterior do cleitro sem reentrância ou com forte reentrância (no lote MZUSP 38667). Nadadeiras pélvicas, com i,7 raios, ultrapassam a origem da nadadeira anal, atingindo o segundo raio ramificado, até o terceiro ou quarto no lote ANSP 141509. Linha lateral incompleta com 7-14 escamas perfuradas (14 no lado esquerdo/ dez no direito do holótipo, média $=9,8 ; \mathrm{n}=18$ ). Seis fileiras de escamas entre a origem da nadadeira dorsal e a linha lateral; quatro a cinco entre a linha lateral e a origem da nadadeira anal. 
Tabela III. Medidas de P. napoatilis sp. nov., holótipo MCZ 51485. (n) número de exemplares, incluindo o holótipo.

\begin{tabular}{|c|c|c|c|c|c|}
\hline \multirow{2}{*}{ Medidas } & \multirow{2}{*}{ Holótipo } & \multicolumn{4}{|c|}{ Limites } \\
\hline & & $\mathrm{n}$ & Mínimo & Máximo & Média \\
\hline Comprimento padrão (mm) & 32,6 & 37 & 21,5 & 47,5 & 33,4 \\
\hline \multicolumn{6}{|c|}{ Porcentagens do comprimento padrão } \\
\hline Altura do corpo & 35,3 & 37 & 28,4 & 37,0 & 33,0 \\
\hline Comprimento pré-dorsal & 50,3 & 37 & 45,6 & 51,0 & 48,6 \\
\hline Comprimento pré-ventral & 36,2 & 27 & 34,1 & 37,6 & 36,0 \\
\hline Comprimento pré-anal & 48,5 & 37 & 47,2 & 51,4 & 48,9 \\
\hline Comprimento ped. caudal & 8,9 & 37 & 6,7 & 9,6 & 8,6 \\
\hline Altura ped. caudal & 8,3 & 37 & 6,1 & 9,1 & 7,9 \\
\hline Comprimento nad. peitoral & 21,2 & 36 & 18,3 & 21,7 & 20,1 \\
\hline Comprimento nad. pélvica & 15,9 & 35 & 14,7 & 18,3 & 16,7 \\
\hline Distância peitoral-pélvica & 10,1 & 37 & 9,2 & 11,4 & 10,3 \\
\hline Distância pélvica-anal & 10,7 & 37 & 9,2 & 12,1 & 10,7 \\
\hline Dist. occipital-dorsal & 27,0 & 37 & 21,9 & 28,4 & 26,6 \\
\hline Distância dorsal-adiposa & 29,1 & 37 & 26,1 & 30,5 & 28,8 \\
\hline Comprimento cabeça & 24,5 & 37 & 22,4 & 27,9 & 24,6 \\
\hline Comprimento focinho & 5,2 & 37 & 5,1 & 7,0 & 5,9 \\
\hline Comprimento maxilar & 6,7 & 37 & 5,9 & 7,8 & 6,7 \\
\hline Espaço interorbital & 7,4 & 37 & 6,3 & 7,9 & 7,0 \\
\hline Diâmetro órbita & 11,3 & 37 & 9,1 & 11,9 & 10,7 \\
\hline \multicolumn{6}{|c|}{ Porcentagens do comprimento da cabeça } \\
\hline Comprimento focinho & 21,2 & 37 & 21,2 & 26,9 & 24,0 \\
\hline Diâmetro órbita & 46,2 & 37 & 37,7 & 48,8 & 43,5 \\
\hline Comprimento maxilar & 27,5 & 37 & 24,4 & 30,8 & 27,3 \\
\hline Espaço interorbital & 30,0 & 37 & 24,3 & 34,1 & 28,4 \\
\hline
\end{tabular}

Presença ou ausência de uma escama entre 1-4 pares de escamas pré-ventrais, localizadas entre as origens das nadadeiras peitorais e pélvicas. Ramo superior do primeiro arco branquial com 3-5 rastros (quatro no holótipo, três em um parátipo e cinco em dois, média $=4, n=34$ ) e ramo inferior com 7-9 (oito no holótipo, sete em um parátipo, média $=8,5 ; \mathrm{n}=34$ ). Vértebras totais 37 , pré-caudais 15 e caudais 22. Quatro supraneurais.

Coloração em álcool. A coloração geral do corpo é amarela. Região laterodorsal com cromatóforos dispostos principalmente na borda das escamas. Região lateroventral, entre as axilas das nadadeiras peitorais e aproximadamente a metade da distância entre as origens das nadadeiras pélvicas e da nadadeira anal basicamente desprovida de pigmentação ou muito pouco pigmentada. Na região entre a linha lateral e a nadadeira anal, os cromatóforos dispõem-se em forma de $>$, demarcando os mioseptos, e espalhados uniformemente sobre as escamas. Imediatamente acima da nadadeira anal, os cromatóforos dispõem-se transversalmente ao eixo horizontal do corpo, no nível de cada raio da nadadeira. Região dorsal da cabeça e dorso do corpo tão pigmentados quanto a região laterodorsal. Opérculo claro, com pigmentos somente na região superior. Mancha umeral, presente somente nas fêmeas, inconspícua e oblíqua, situada acima da sétima a oitava escama da linha lateral e desde a terceira (ou imediatamente após a primeira ou segunda) até a quarta ou a quinta costela, contada a partir do final do pseudotímpano. Seu comprimento horizontal é menor do que a metade do diâmetro orbital. Uma fraca linha escura (nem sempre visualizada), situada na região médio-lateral do corpo, estende-se desde a região imediatamente após a mancha umeral até a mancha do pedúnculo caudal, sendo relativamente mais forte no nível da vertical que passa pela origem da nadadeira dorsal. Pedúnculo caudal com uma estreita mancha triangular, em machos e fêmeas, que se prolonga fortemente entre os raios medianos da nadadeira caudal. Nadadeira caudal 
com pigmentos dispostos uniformemente ao longo das margens dos raios. Nadadeira dorsal com pigmentos nas membranas inter-radiais até aproximadamente o quinto raio ramificado, clara posteriormente; região mais basal geralmente clara, sem ou com poucos pigmentos; primeiro raio da nadadeira dorsal pigmentado. Nadadeiras peitorais e pélvicas claras, com poucos pigmentos ao longo das margens de alguns raios. Nadadeira anal totalmente pigmentada ou com parte da região mediana despigmentada; a porção basal e a margem, ou somente a margem, podem apresentar pigmentos mais expandidos que os da região mediana.

Dimorfismo sexual. Foram identificados 21 machos com 25,5 a 47,5 mm de CP (ANSP 141509, FMNH 104066, MCP 43594, MCZ 168152 e MZUSP 38667. Apresentam ganchos nas nadadeiras peitorais e anal. Nadadeira anal com nódulos na margem posterior do segundo ramo do primeiro ao quinto raio não-ramificado, um nódulo por segmento ou ganchos do primeiro ou segundo até, no máximo, o décimo nono raio ramificado. Nadadeiras peitorais com ganchos retrorsos ao longo da margem dorsal dos raios ramificados, do primeiro até no máximo o penúltimo raio. Mancha umeral ausente nos machos e presente nas fêmeas.

Material examinado. Holótipo. Equador, Napo: Rio Napo e afluentes (próximo a Coca, $0^{\circ} 28^{\prime} \mathrm{S} 76^{\circ} 56^{\prime} \mathrm{W}$ ), 30/IX/1971, T. Roberts leg., MCZ 51485 (32,6 mm CP). Parátipos. EQUADOR, Napo: Rio Panayacu $\left(0^{\circ} 25^{\prime} \mathrm{S} 76^{\circ} 07^{\prime} \mathrm{W}\right), \mathrm{XI} / 1964$, M. Olalla leg., ANSP 141509 (6, 28,4-36,7 mm CP); Rio Napo e afluentes (próximo a Coca, $0^{\circ} 28^{\prime} \mathrm{S} 76^{\circ} 56^{\prime} \mathrm{W}$ ), T. Roberts leg., 30/IX/1971, coletados juntamente com o holótipo, MCP 43594 (2, 33,1-33,7), MCZ 168152 (8, 29,9-35,1 mm CP), MEPN 8897 (2, 29,5-30,6 mm CP), USNM 391837 (1, 32,9 mm CP); tributário do Rio Jatuncocha (2 km acima da Laguna Jatuncocha, sistema do Rio Napo), 26/ X/1981, D. Stewart \& M. Ibarra leg., MCP 43665 (30,7 mm CP d $\& \mathrm{c})$, MZUSP 38667 (9, 21,5-35,0 mm CP); alto Rio Tiputini $\left(0^{\circ}\right.$ 44'30"S, 7653'00"W), 03/XI/1981, D.J.Stewart, M.C. Ibarra \& R. Barriga leg., FMNH 104066 (10, 36,7- 47,5 mm CP), MCP 44064 (2, 42,3-42,8 mm CP), MEPN 9482 (39,2-41,0 mm CP).

Distribuição. Sistema do Rio Napo, alto Rio Amazonas, Equador (Fig. 3).

Etimologia. Do latim atilis, lugar onde ocorre. Em referência ao sistema hidrográfico do Rio Napo, onde a espécie ocorre.

\section{Phenacogaster ojitatus sp. nov.} Fig. 6

Diagnose. Phenacogaster ojitatus distingue-se de todas as demais espécies do gênero, exceto de $P$. tegatus, por apresentar pequeno diâmetro orbital $(33,0-36,9 \%$ vs 36,6-48,1\% do CC nas demais) e, exceto de $P$. megalostictus, $P$. simulatus e $P$. tegatus, pelo comprimento da cabeça em indivíduos acima de $30,0 \mathrm{~mm}$ de CP (26,7-29,3\% vs 23,6-27,4\% do CP nas demais). De $P$. tegatus, difere por apresentar a mancha umeral próxima ao pseudotímpano ( $v s$ distante do pseudotímpano, na vertical que passa pela origem da nadadeira dorsal).
Descrição. Dados morfométricos na tabela IV. Corpo comprimido, perfil dorsal convexo desde o focinho até a origem da nadadeira dorsal, algumas vezes com leve concavidade à frente da base do processo supra-occipital; declinando-se e tornandose reto desde a origem da nadadeira dorsal até o fim do pedúnculo caudal; algumas vezes convexo ao longo da nadadeira dorsal e côncavo no pedúnculo caudal. Perfil ventral do corpo acentuadamente convexo da extremidade da mandíbula até a origem das nadadeiras peitorais, continuando convexo deste ponto até a origem da nadadeira anal; convexidade variável, quase retilíneo em alguns espécimes e, geralmente, retilíneo entre a origem das nadadeiras pélvicas e a da nadadeira anal; elevando-se e continuando reto ou levemente convexo ao longo da base da nadadeira anal e reto ou levemente côncavo no pedúnculo caudal. Extremidade da maxila superior ultrapassa levemente ou situase no mesmo nível da ponta da mandíbula. Abertura bucal situada abaixo da horizontal que passa pela metade do diâmetro da órbita, aproximadamente pela metade. Margem ventral do terceiro infra-orbital separada da margem horizontal do préopérculo por um espaço de aproximadamente $1 / 4$ a 1/5 do seu comprimento; margem posterior separada da margem vertical do pré-opérculo por um espaço menor, podendo quase contatála. Duas fileiras de dentes no pré-maxilar; fileira externa geralmente interrompida, com 6-9 dentes totais (seis no holótipo, média $=7,4 ; \mathrm{n}=18$ ), sendo $2-3$ tricúspides na região medial (às vezes o último cônico), maiores que os da região lateral e 4-7, cônicos mais delgados na região lateral (um parátipo com sete). Fileira externa completa, com oito dentes, do lado direito de três parátipos, sendo os três primeiros dentes tricúspides maiores que os demais, seguidos de dentes cônicos mais delgados. Fileira interna com 9-11 dentes (10 no holótipo, média = 9,6; $\mathrm{n}$ =18), sendo os três primeiros tricúspides maiores e mais largos que os demais, seguidos de dentes tricúspides e cônicos menores e mais delgados. Alguns espécimes possuem um dente cônico localizado na porção posterior do pré-maxilar, entre as fileiras externa e interna. Maxilar com 24-33 dentes cônicos (33 no holótipo, média $=26,8 ; \mathrm{n}=11$ ) situados ao longo de quase toda a margem ventral. Dentário com 16-18 dentes em uma única fileira, os cinco ou seis primeiros tricúspides (um parátipo com sete, o último bicúspide), seguidos de 10 a 11 dentes cônicos menores e mais delgados. Nadadeira dorsal com ii,9 raios (10 em um parátipo). Origem da nadadeira dorsal localizada próxima à metade do corpo. Nadadeira anal com iv,29-32 (29 no holótipo, média $=30,3 ; n=20$ ). Origem da nadadeira anal localizada próxima à vertical que passa pela base do terceiro ou quarto raio ramificado da nadadeira dorsal. Margem anterior da nadadeira anal levemente côncava, com o último raio não-ramificado e os quatro a cinco primeiros raios ramificados maiores que os demais (o último não-ramificado e os três primeiros ramificados aproximadamente do mesmo tamanho). Nadadeiras peitorais com i,11-14 raios (13 no holótipo, média = 12,3; $\mathrm{n}$ =20), extremidade do raio mais longo ultrapassa a origem das nadadeiras pélvicas, alcançando a metade dessas nadadeiras; raios 


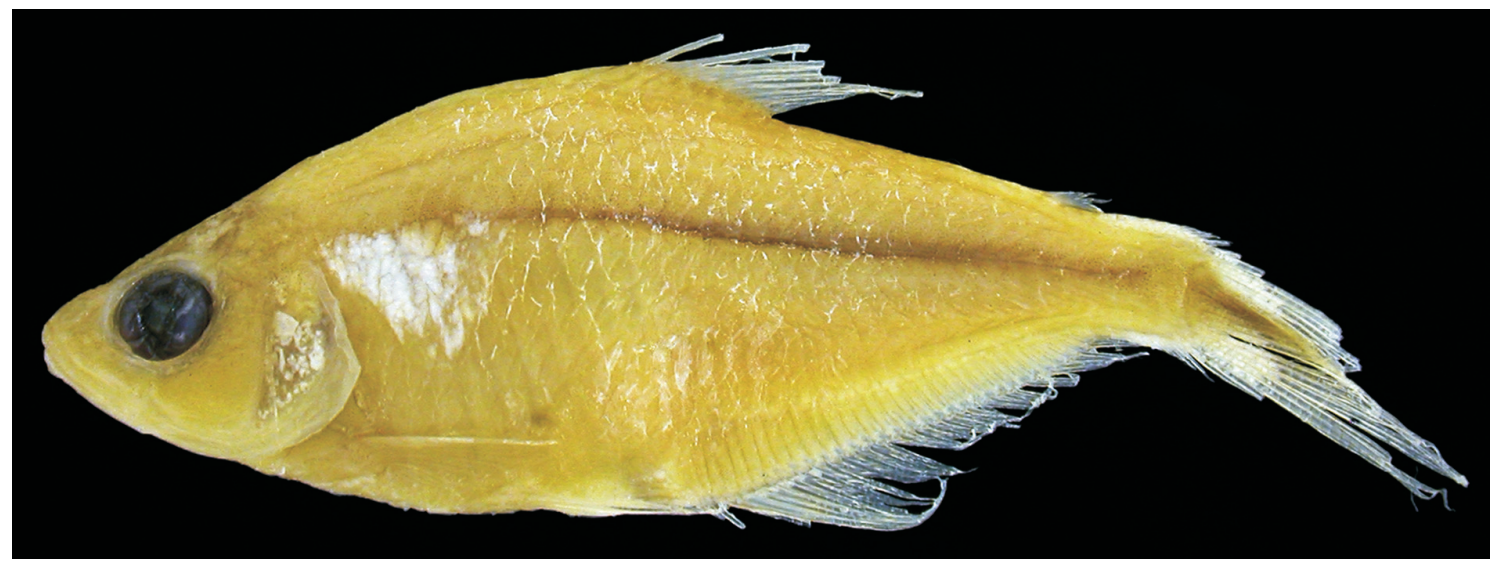

Figura 6. Phenacogaster ojitatus sp. nov., MZUSP 30551, holótipo, 36,3 mm CP, Rio Curuá, Pará.

Tabela IV. Medidas de P. ojitatus sp. nov., holótipo MZUSP 30551. (n) Número de exemplares, incluindo o holótipo.

\begin{tabular}{|c|c|c|c|c|c|}
\hline \multirow{2}{*}{ Medidas } & \multirow{2}{*}{ Holótipo } & \multicolumn{4}{|c|}{ Limites } \\
\hline & & $\mathrm{n}$ & Mínimo & Máximo & Média \\
\hline Comprimento padrão (mm) & 36,3 & 20 & 26,4 & 36,3 & 31,1 \\
\hline \multicolumn{6}{|c|}{ Porcentagens do comprimento padrão } \\
\hline Altura do corpo & 37,4 & 20 & 32,0 & 37,5 & 34,0 \\
\hline Comprimento pré-dorsal & 53,7 & 20 & 51,3 & 54,9 & 52,9 \\
\hline Comprimento pré-ventral & 40,5 & 20 & 37,3 & 41,6 & 39,9 \\
\hline Comprimento pré-anal & 60,6 & 20 & 54,4 & 60,6 & 57,0 \\
\hline Comprimento ped. caudal & 8,5 & 20 & 6,6 & 9,9 & 8,4 \\
\hline Altura ped. caudal & 9,4 & 20 & 8,1 & 10,1 & 9,4 \\
\hline Comprimento nad. peitoral & 22,6 & 16 & 22,0 & 25,2 & 23,8 \\
\hline Comprimento nad. pélvica & 21,2 & 20 & 18,8 & 21,6 & 20,1 \\
\hline Distância peitoral-pélvica & 11,6 & 20 & 9,5 & 11,6 & 10,3 \\
\hline Distância pélvica-anal & 12,9 & 20 & 11,6 & 13,9 & 12,6 \\
\hline Dist. occipital-dorsal & 30,3 & 20 & 26,4 & 30,3 & 28,3 \\
\hline Distância dorsal-adiposa & 26,1 & 20 & 24,2 & 26,9 & 25,3 \\
\hline Comprimento cabeça & 29,2 & 20 & 26,7 & 30,3 & 28,5 \\
\hline Comprimento focinho & 8,0 & 20 & 7,0 & 8,5 & 7,6 \\
\hline Comprimento maxilar & 7,7 & 19 & 6,7 & 7,8 & 7,3 \\
\hline Espaço interorbital & 8,0 & 20 & 7,2 & 8,7 & 7,7 \\
\hline Diâmetro órbita & 9,6 & 20 & 9,3 & 10,6 & 9,9 \\
\hline \multicolumn{6}{|c|}{ Porcentagens do comprimento da cabeça } \\
\hline Comprimento focinho & 27,3 & 20 & 24,5 & 28,7 & 26,8 \\
\hline Diâmetro órbita & 33,0 & 20 & 33,0 & 36,9 & 34,8 \\
\hline Comprimento maxilar & 26,4 & 20 & 25,6 & 30,3 & 27,2 \\
\hline Espaço interorbital & 33,0 & 19 & 23,7 & 27,4 & 25,6 \\
\hline
\end{tabular}


totalmente desenvolvidos no menor indivíduo examinado de 26,4 mm de CP. Margem posterior do cleitro geralmente sem reentrância ou levemente ondulado, alguns com leve reentrância. Nadadeiras pélvicas, com i,7 raios (dois parátipos com oito), ultrapassam a origem da nadadeira anal, atingindo geralmente o segundo ou terceiro raio ramificado dessa nadadeira. Ramo superior do primeiro arco branquial com 4-6 rastros (cinco no holótipo, média $=5, \mathrm{n}=20$, quatro e seis em um parátipo) e ramo inferior com 8-9 rastros (nove no holótipo, média $=8,9 ; \mathrm{n}$ $=20$ ). Vértebras totais 34-35, pré-caudais 15 e caudais 19-20. Quatro supraneurais.

Coloração em álcool. A coloração geral do corpo é amarela. Região laterodorsal e lateroventral, entre a linha lateral e nadadeira anal, com cromatóforos castanhos em forma de $>$, demarcando os mioseptos e espalhados uniformemente sobre as escamas. Região lateroventral, entre as nadadeiras peitorais e a origem da nadadeira anal, desprovida de pigmentação. Opérculo com pigmentos, principalmente na região superior e mediana. Região dorsal da cabeça e dorso do corpo mais intensamente pigmentados que o restante do corpo. Mancha umeral conspícua, verticalmente alongada, situada desde a primeira ou imediatamente à frente da segunda até a quarta costela, contada a partir do pseudotímpano. Seu comprimento horizontal é levemente maior ou igual à metade do diâmetro orbital. Uma acentuada linha escura, na região médio-lateral do corpo, estende-se desde a região posterior da mancha umeral até a mancha do pedúnculo caudal; imediatamente acima e abaixo dessa linha estende-se uma faixa com pigmentos relativamente esparsos. Presença de uma mancha triangular, no pedúnculo caudal, que se prolonga fortemente entre e até o final dos raios medianos da nadadeira caudal. Nadadeira caudal com pigmentos ao longo dos raios. Nadadeira dorsal com pigmentos ao longo das membranas inter-radiais e ao longo da margem posterior dos raios. Nadadeiras peitorais e pélvicas com pigmentos ao longo das margens anterior e posterior dos raios. Nadadeira anal totalmente pigmentada ou somente com a margem sem pigmentos.

Material examinado. Holótipo. Brasil, Pará: Rio Curuá (Serra do Cachimbo), 15/VIII/1984, M. Goulding leg., MZUSP 30551, 36,3 mm CP. Parátipos. Brasil, Pará: Rio Curuá (Serra do Cachimbo), 15/VIII/1984, M. Goulding leg., coletados juntamente com o holótipo, MCP 43785 (4, 29,7-32,3 mm CP), MZUSP 100922 (24, 28,4-33,5 mm CP, 2 d\&c, 31,2-30,5 mm CP).

Distribuição. Conhecida somente da localidade-tipo, Rio Curuá, Serra do Cachimbo, sistema do Rio Xingu (Fig. 3).

Etimologia. Combinação da palavra espanhola, ojito, olho pequeno e atus, do latim, posse. Em menção ao pequeno olho da espécie.

\section{Phenacogaster prolatus sp. nov.}

\section{Figs 7-8}

Diagnose. A conspícua mancha umeral que se estende sobre a metade superior da escama da linha lateral, Fig. 8 (acima ou no máximo levemente sobre pequena parte da escama da linha lateral nas demais espécies, exceto em P. megalostictus), o terceiro infra-orbital pequeno, distintamente separado da margem horizontal do pré-opérculo por um espaço de $1 / 2$ a $1 /$ 4 do seu comprimento (vs $1 / 5$ ou mais nas demais espécies, raramente $1 / 4$; exceto em $P$. jancupa, com $1 / 3$ a $1 / 4)$, o maxilar relativamente grande com $29,3-35,0 \%$ do CC ( $v s$ pequeno, 21,3$30,9 \%$ nas demais espécies, e no máximo $31,5 \%$ em $P$. megalostictus; exceto no holótipo de P. suborbitalis, com 31,2\%) e a ausência de mancha no pedúnculo caudal ( $v s$ mancha presente, exceto em $P$. carteri e nas espécies do complexo $P$. pectinatus) distinguem $P$. prolatus das demais espécies do gênero. Da espécie simpátrica no sistema do Rio Negro, P. retropinnus, pode ser ainda distinta pela ausência de mancha no pedúnculo caudal ( $v s$ presença), maior número de raios ramificados na nadadeira anal (33-38 vs 28-34) e menor comprimento pré-anal (47,8-52,6\% vs $52,6-58,7 \%$ no CP).

Descrição. Dados morfométricos na tabela V. Corpo comprimido, perfil dorsal levemente convexo a quase reto do focinho até o final da região interorbital, continuando côncavo até a base do processo supra-occipital - em alguns espécimes de até aproximadamente $35,0 \mathrm{~mm}$ de comprimento padrão não há concavidade à frente do processo supra-occipital - elevando-se e tornando-se convexo até a origem da nadadeira dorsal; declinando-se e tornando-se reto desde a origem da nadadeira dorsal até o fim do pedúnculo caudal; reto a levemente convexo ao longo da base da nadadeira dorsal. Perfil ventral do corpo convexo da extremidade da mandíbula até a origem da nadadeira anal, sendo acentuadamente convexo na cabeça e levemente convexo ou reto entre a origem das nadadeiras peitorais até a origem da nadadeira anal; elevando-se e tornando-se reto a levemente convexo ao longo da base da nadadeira anal e reto a levemente côncavo no pedúnculo caudal. Extremidade da maxila superior situa-se no mesmo nível da ponta da mandíbula ou, raramente, ultrapassa levemente a ponta da mandíbula. Boca situada abaixo da linha mediana horizontal da órbita. Terceiro infra-orbital comparativamente reduzido, sua margem ventral separada da margem horizontal do pré-opérculo por um grande espaço de $1 / 2$ a $1 / 4$ do seu comprimento, aumentando em direção posterior até deixar uma ampla área nua no ângulo do préopérculo; margem posterior separada da margem vertical do préopérculo por um espaço semelhante ou pouco menor, nunca contatando-a. Duas fileiras de dentes no pré-maxilar, todos tricúspides; fileira externa completa, raramente interrompida, com 5-11 dentes totais (média = 8,3; $\mathrm{n}=42$ ). Quando completa, possui 6-11 dentes (seis em um parátipo) que decrescem em tamanho, geralmente os três primeiros maiores que os demais. Quando interrompida, possui dois a três dentes na região medial e 2-7 na região lateral, os da região medial são maiores que os demais. Fileira interna com 7-11 dentes (sete em um espécimetipo, média $=9,4 ; n=38$ ), geralmente os três primeiros maiores que os demais. Alguns espécimes possuem um dente localizado na porção posterior do pré-maxilar, entre as fileiras externa e interna. Maxilar com 27-38 dentes tricúspides (34, média = 32,2; 

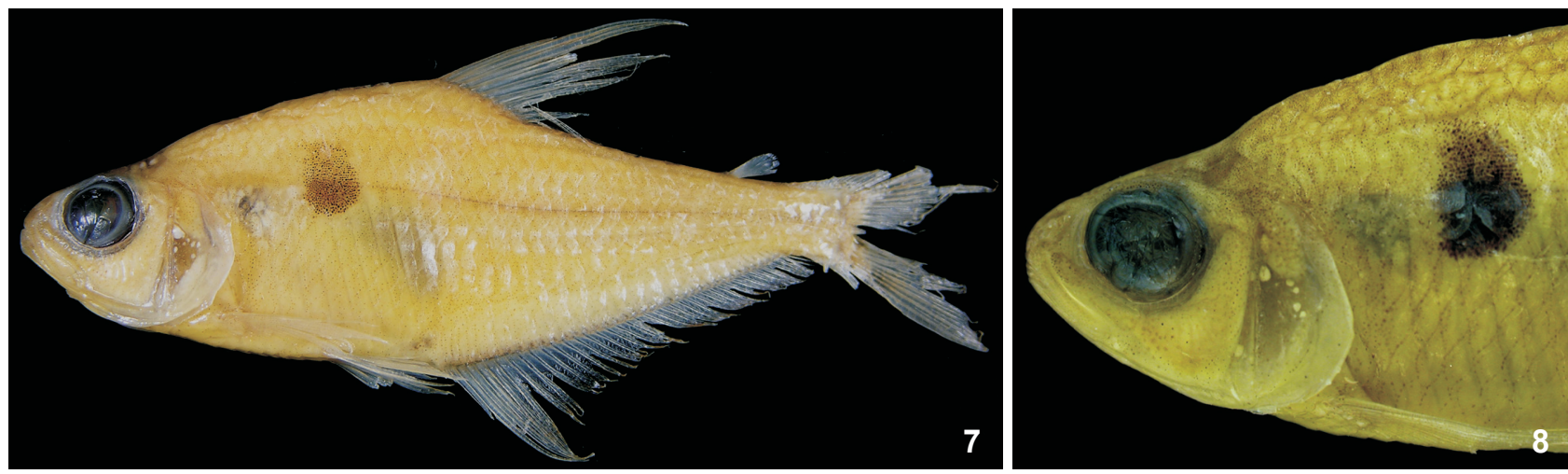

Figuras 7-8. Phenacogaster prolatus sp. nov: (7) MBUCV-V 33242, holótipo, 49,9 mm CP, afluente do caño Urami, Venezuela; (8) USNM 270337, parátipo, 48,2 mm CP, afluente do caño Chola, Venezuela, detalhe da localização da mancha umeral sobre a linha lateral.

Tabela V. Medidas de P. prolatus sp. nov., holótipo MBUCV-V 33242. (n) Número de exemplares, incluindo o holótipo.

\begin{tabular}{|c|c|c|c|c|c|c|c|c|c|}
\hline \multirow{2}{*}{ Medidas } & \multirow{2}{*}{ Holótipo } & \multicolumn{4}{|c|}{ Limites material-tipo } & \multicolumn{4}{|c|}{ Limites material não-tipo } \\
\hline & & $\mathrm{n}$ & Mínimo & Máximo & Média & $\mathrm{n}$ & Mínimo & Máximo & Média \\
\hline Comprimento padrão (mm) & 49,9 & 55 & 31,5 & 49,9 & 37,7 & 7 & 32,1 & 47,3 & 41,6 \\
\hline \multicolumn{10}{|c|}{ Porcentagens do comprimento padrão } \\
\hline Altura do corpo & 34,7 & 55 & 29,8 & 34,7 & 32,3 & 7 & 30,8 & 34,3 & 33,1 \\
\hline Comprimento pré-dorsal & 50,3 & 55 & 47,9 & 51,9 & 50,0 & 7 & 48,3 & 50,9 & 49,9 \\
\hline Comprimento pré-ventral & 36,2 & 54 & 37,6 & 40,0 & 38,4 & 7 & 35,9 & 38,1 & 36,9 \\
\hline Comprimento pré-anal & 49,7 & 54 & 47,8 & 52,6 & 50,5 & 7 & 49,3 & 52,7 & 50,8 \\
\hline Comprimento ped. caudal & 8,8 & 55 & 6,9 & 9,2 & 8,2 & 7 & 8,1 & 9,6 & 8,9 \\
\hline Altura ped. caudal & 7,8 & 55 & 6,4 & 7,9 & 7,1 & 7 & 8,1 & 9,5 & 8,9 \\
\hline Comprimento nad. peitoral & 19,6 & 55 & 19,1 & 21,3 & 20,1 & 6 & 20,7 & 23,9 & 21,7 \\
\hline Comprimento nad. pélvica & 18,4 & 55 & 15,4 & 20,6 & 18,4 & 6 & 17,3 & 19,6 & 18,3 \\
\hline Distância peitoral-pélvica & 12,8 & 55 & 8,1 & 9,5 & 8,7 & 7 & 7,5 & 11,0 & 9,4 \\
\hline Distância pélvica-anal & 15,6 & 55 & 9,5 & 11,0 & 10,4 & 7 & 10,3 & 12,3 & 10,9 \\
\hline Dist. occipital-dorsal & 27,8 & 55 & 23,6 & 27,6 & 25,1 & 7 & 25,5 & 27,4 & 26,4 \\
\hline Distância dorsal-adiposa & 25,6 & 55 & 26,7 & 28,6 & 27,7 & 7 & 26,9 & 29,3 & 27,7 \\
\hline Comprimento cabeça & 25,6 & 55 & 25,1 & 28,3 & 26,9 & 7 & 24,1 & 26,8 & 25,8 \\
\hline Comprimento focinho & 6,6 & 55 & 5,6 & 7,6 & 6,7 & 7 & 5,7 & 7,1 & 6,4 \\
\hline Comprimento maxilar & 8,4 & 55 & 7,6 & 9,5 & 8,5 & 7 & 7,5 & 8,5 & 8,0 \\
\hline Espaço interorbital & 6,0 & 55 & 5,4 & 7,0 & 6,0 & 6 & 6,3 & 7,3 & 6,8 \\
\hline Diâmetro órbita & 10,6 & 55 & 10,6 & 12,3 & 11,5 & 7 & 10,3 & 11,5 & 10,8 \\
\hline \multicolumn{10}{|c|}{ Porcentagens do comprimento da cabeça } \\
\hline Comprimento focinho & 25,8 & 55 & 21,0 & 28,4 & 25,1 & 7 & 23,7 & 27,2 & 25,0 \\
\hline Diâmetro órbita & 41,4 & 55 & 40,4 & 45,5 & 42,9 & 7 & 39,8 & 43,7 & 41,8 \\
\hline Espaço interorbital & 23,4 & 55 & 20,2 & 25,0 & 22,3 & 6 & 25,6 & 28,2 & 26,6 \\
\hline Comprimento maxilar & 32,8 & 55 & 29,3 & 35,0 & 31,4 & 7 & 29,1 & 32,5 & 30,9 \\
\hline
\end{tabular}


$\mathrm{n}=49$ ) ao longo de quase todo seu comprimento. Dentário com 15-19 dentes tricúspides dispostos em uma única fileira, os 5-7 primeiros maiores e mais largos que os demais. Nadadeira dorsal com ii,9 raios. Origem da nadadeira dorsal localizada próxima à metade do corpo. Nadadeira anal com iii-iv,33-38 raios (35 no holótipo, média $=35,4 ; \mathrm{n}=53$ ). Origem da nadadeira anal localizada na vertical que passa entre o primeiro e o quarto raio da nadadeira dorsal. Margem anterior da nadadeira anal côncava, o último raio não-ramificado e os cinco ou seis primeiros ramificados maiores que os demais; os três primeiros aproximadamente do mesmo tamanho; uma bainha de até pelo menos 10 escamas ao longo da base do primeiro raio não-ramificado até o oitavo raio ramificado. Nadadeiras peitorais com i,12-16 raios ( 15 no holótipo, média $=13,8 ; \mathrm{n}=55$ ). Extremidade posterior do raio mais longo ultrapassa a origem das nadadeiras pélvicas, atingindo, aproximadamente, ou ultrapassando a metade das nadadeiras pélvicas; nadadeiras peitorais não-desenvolvidas em um parátipo de $26,1 \mathrm{~mm}$ de $\mathrm{CP}$ e parcialmente em outro de 31,4 mm de CP. Entretanto, encontra-se desenvolvida em um parátipo de 29,8 $\mathrm{mm}$ de $\mathrm{CP}$ e em outro de $31,4 \mathrm{~mm}$ de CP. Margem posterior do cleitro com reentrância. Nadadeiras pélvicas, com i,7 raios, ultrapassam a origem da nadadeira anal, atingindo o segundo ou ultrapassando levemente o terceiro raio ramificado. Linha lateral completa, com aproximadamente 3841 escamas perfuradas (38 no holótipo; $\mathrm{n}=11$, contagem estimada em sete exemplares). Seis a sete fileiras de escamas entre a origem da nadadeira dorsal e a linha lateral (sete no holótipo, contadas somente em quatro espécimes; cinco a seis fileiras (cinco no holótipo, média $=5,6 ; \mathrm{n}=42$ ) entre a origem da nadadeira anal e a linha lateral. Uma escama pode estar ou não sobreposta entre 1-6 pares de escamas ventrais, localizadas entre as origens das nadadeiras peitorais e pélvicas. Ramo superior do primeiro arco branquial com 4-6 rastros (seis no holótipo, média = 4,9; $\mathrm{n}$ = 63) e ramo inferior com 9-11 rastros (10 no holótipo, média = $9,8 ; \mathrm{n}=64)$. Vértebras totais 37 , pré-caudais 15 e caudais 22 . Quatro supraneurais.

Coloração em álcool. A coloração geral do corpo é amarela. Região laterodorsal com pigmentos castanhos uniformemente espalhados ou quase sem pigmentação. Na região lateroventral, entre a linha lateral e a nadadeira anal, os pigmentos, além de estarem espalhados uniformemente sobre as escamas, dispõem-se em forma de $>$, demarcando os mioseptos. Imediatamente acima da base da nadadeira anal, os cromatóforos situam-se transversalmente em relação ao eixo do corpo, logo à frente de cada raio da nadadeira. Opérculo, em geral totalmente pigmentado, com menos pigmentos na região mais ventral. Região dorsal da cabeça e dorso do corpo intensamente pigmentados, algumas vezes formando linhas concêntricas na região dorsal do focinho. Mancha umeral conspícua e verticalmente alongada, com a região superior mais difusa, situada ao nível da sétima a décima escama ou mais raramente da sexta a nona escama da linha lateral, estendendo-se principalmente sobre a oitava e nona escamas da linha lateral (raramente sobre a sexta até oitava ou sétima e oitava escamas) e atingindo a metade superior da oitava; situa-se, geralmente, desde a terceira até a sexta costela, podendo situar-se da segunda até a quinta, contada a partir do final do pseudotímpano. Seu comprimento horizontal geralmente é maior ou, no máximo, igual à metade do diâmetro orbital. Uma linha escura, na região médio-lateral do corpo e acima da linha lateral, estende-se desde a região posterior da mancha umeral até o final do pedúnculo caudal. Pedúnculo caudal sem mancha. Nadadeira dorsal com pigmentos entre as membranas radiais, exceto na metade ventral, após o segundo ou terceiro raio ramificado; primeiro raio geralmente mais pigmentado que os demais. Nadadeiras peitorais e pélvicas uniformemente pigmentadas, com pigmentos dispostos ao longo das margens dos raios. Nadadeira anal com a margem escura, base e região mediana claras; membranas inter-radiais com pigmentos até, aproximadamente, o sexto raio ramificado. Nadadeira caudal uniformemente pigmentada, com pigmentos dispostos principalmente ao longo das margens dos raios; uma linha vertical escura vertical na base dos lobos superior e inferior.

Dimorfismo sexual. Não foram encontrados ganchos nas nadadeiras dos parátipos examinados. Veja Comentários abaixo.

Material examinado. Holótipo. Venezuela, Amazonas: pequeno afluente do Caño Urami (próximo a Santa Lucia, depto. Río Negro, $\left.01^{\circ} 17^{\prime} \mathrm{N} 66^{\circ} 51^{\prime} \mathrm{W}\right), 06 / \mathrm{XII} / 1984$, R. Vari et al. leg., MBUCV-V 33242 (49,9 mm CP). Parátipos. BrasiL, Amazonas: Rio Negro (encontro com o Rio Marauiá, X/1979, M. Goulding leg., MZUSP 31207 (2, 38,0-38, 5 mm CP). Venezuela, Amazonas: Rio Autana (pequeno riacho cerca de $5 \mathrm{~km}$ abaixo de Raudal Peresa, $\left.04^{\circ} 46^{\prime} \mathrm{N} 67^{\circ} 19^{\prime} \mathrm{W}\right), 3 / \mathrm{XI} / 1985$, B. Chernoff \& R. Royero leg., ANSP 159970 (6, 26,1-35,9 mm CP); Caño Chola (depto. Río Negro, $\left.01^{\circ} 58^{\prime} \mathrm{N} 67^{\circ} \mathrm{W}\right), 5 / \mathrm{XII} / 1984$, R. Vari et al. leg., USNM 270337 (11, 35,5-48,1 mm CP); Caño Manu (tributário do Canal Casiquiare, aproximadamente $250 \mathrm{~m}$ de Solano, depto. Río Negro), 7/XII/1984, R. Vari et al. leg., USNM 272119 (13, 31,5-46,3 $\mathrm{mm} \mathrm{CP}$ ); riacho Tremblador (parte alta, depto Río Negro, $01^{\circ} 58^{\prime} \mathrm{N}$ $\left.67^{\circ} 00^{\prime} \mathrm{W}\right), 5 / \mathrm{XII} / 1984$, R. Vari et al. leg., USNM 272120 (11, 34,249,5 mm CP); Caño Loro (depto. Río Negro, 0159’ ${ }^{\circ} 66^{\circ} 58^{\prime} \mathrm{W}$ ), 7/XII/1984, A. Machado \& D. Ibarra leg., USNM 272121 (26, 32,9-48,1 mm CP); Caño Urami (próximo a Santa Lucia, depto. Río Negro, $\left.01^{\circ} 17^{\prime} \mathrm{N} 66^{\circ} 51^{\prime} \mathrm{W}\right), 6 / \mathrm{XII} / 1984$, R. Vari et al. leg., coletados juntamente com o holótipo, MBUCV-V 33243 (5, 35,940,9 mm CP), MCP 41059 (5, 36,1-39,0 mm CP, 1 d\&c, 36, 2 mm CP), USNM 272125 (19, 32,5-47,6 mm CP). Não-tipos. VeneZueLA, Amazonas: pequeno riacho na margem direita do Rio Cataniapo (cerca de $2 \mathrm{Km}$ antes do Salto Kiere), 21/XII/1983, R. Royero et al. leg., MBUCV-V 14441 (6, 31,8-46,0 mm CP), pequeno riacho na margem direita do Rio Cataniapo (cerca de $2 \mathrm{Km}$ antes do Salto Kiere), 21/XII/1983, R. Royero et al. leg., MCP 26498 (3, 34,9-41,7 mm CP, 1 d\&c 40,3 mm CP); Rio Cataniapo (na comunidade indígena de Las Paras), 30/III/1983, C. Marrero, MCP 26500 (4, 38,8-48,3 $\mathrm{mm} \mathrm{CP})$. 
Distribuição. Sistema do Rio Orinoco, Canal Casiquiare e Rio Negro, sistema do Rio Amazonas (Fig. 3).

Etimologia. Do latim prolatus, alongado, em relação à extensão do osso maxilar.

Comentários. Os lotes provenientes do Rio Cataniapo possuem todas as características encontradas em $P$. prolatus, exceto por apresentar maior espaço interorbital (25,6-28,2\% vs 20,2-25\% no CC nos parátipos). Nesses lotes, alguns espécimes apresentam pequeníssimos ganchos nas nadadeiras anal, pélvicas e peitorais. Considerando-se que o espaço interorbital pode ser maior em machos do que em fêmeas de algumas espécies do gênero, é provável que os espécimes desses lotes sejam representantes machos da espécie. Entretanto, considerando-se a não-certeza dessa afirmativa, decidiu-se não incluí-los na série-tipo. Myers in Eigenmann \& Myers (1929: 448) registrou em nota de rodapé a provável ocorrência de $P$. megalostictus no Rio Negro, o que foi repetido por Géry (1972: 12, 1977: 530). Não foram encontrados exemplares dessa espécie no extenso material examinado do Rio Negro, mas sim de outra muito similar - identificada aqui como uma nova espécie, $P$. prolatus, a qual também possui dentes do pré-maxilar formando uma fileira contínua e uma grande mancha umeral, estendendo-se sobre as escamas da linha lateral. Entretanto, $P$. megalostictus diferencia-se dessa espécie por apresentar infra-orbital 3 maior, o qual pode alcançar a margem posterior do pré-opérculo e quase alcança a margem inferior (distante da margem posterior e inferior em $P$. prolatus), maior comprimento pré-anal (50,8-58,6\% do CP vs 47,8-52,6\%), maior altura do pedúnculo caudal $(7,5-10,1 \%$ vs $6,4 \%-7,9 \%$ no comprimento padrão em espécimes acima de $30 \mathrm{~mm}$ (Fig. 9) e presença de mancha no pedúnculo caudal em espécimes machos e fêmeas (ausente em $P$. prolatus).

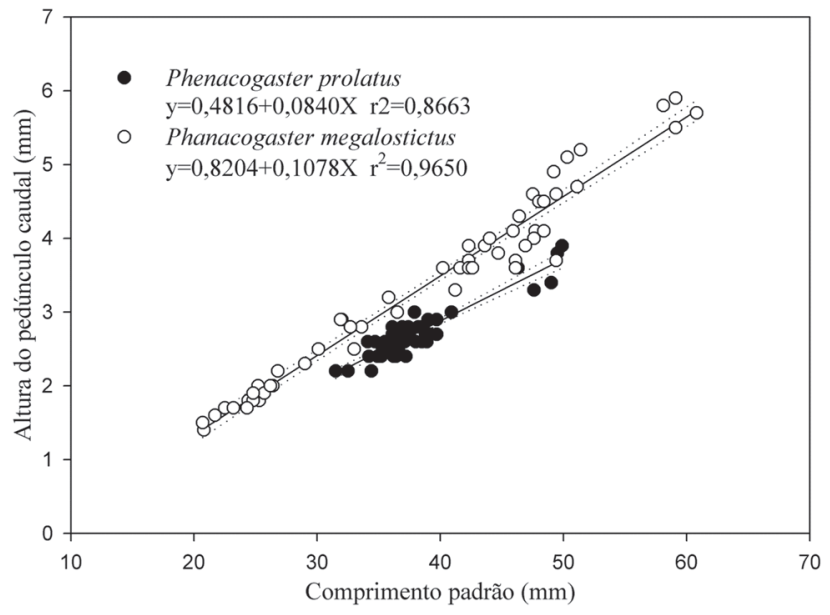

Figura 9. Regressão da altura do pedúnculo caudal em relação ao comprimento padrão de Phenacogaster prolatus e $P$. megalostictus.

\section{Phenacogaster retropinnus sp. nov.}

Fig. 10

Diagnose. Phenacogaster retropinnus distingue-se de $P$. capitulatus, $P$. carteri, $P$. napoatilis, $P$. prolatus e das espécies do complexo $P$. pectinatus por apresentar a origem da nadadeira anal situada na vertical que passa pelos últimos raios da nadadeira dorsal (comprimento pré-anal de 52,6-58,7\% vs 45,1-53,6\% do $\mathrm{CP})$. Das demais espécies do gênero, $P$. retropinnus difere pelos seguintes caracteres: corpo baixo, maior altura de 26,5-32,8\% do CP, em espécimes acima de $30 \mathrm{~mm} \mathrm{CP}$, média $=29,7$ ( $v s, 34,1$ $39,4 \%$ em $P$. capitulatus, 32,5-40,1\% em $P$. franciscoensis, 30,438,4\%, em $P$. megalostictus, 31,0-37,0 em $P$. napoatilis, 32-37,5 em P. ojitatus, 32,2-37,7\% em P. tegatus e 30, 2-38,5 em P. wayana), mancha umeral mais próxima do pseudotímpano do que da origem da nadadeira dorsal ( $v s$ mancha umeral situada na vertical que passa abaixo ou imediatamente à frente da nadadeira dorsal em P. tegatus) mancha umeral não se estendendo sobre as escamas da linha lateral ( $v s$ mancha umeral estendendo-se sobre a linha lateral em $P$. prolatus e $P$. megalostictus), linha lateral completa ( $v$ s incompleta em $P$. capitulatus, $P$. carteri, $P$. napoatilis e $P$. tegatus), nadadeiras pélvicas ultrapassam a origem da nadadeira anal, alcançando do primeiro ao terceiro raio ramificado desta nadadeira ( $v s$ nadadeiras pélvicas alcançam ou ultrapassam levemente a origem da nadadeira anal, atingindo, no máximo, o segundo raio não-ramificado desta nadadeira em $P$. calverti), mancha do pedúnculo caudal relativamente estreita, não se expandindo na parte superior do pedúnculo caudal ( $v s$ mancha do pedúnculo caudal relativamente larga, expandida, principalmente, na parte superior do pedúnculo caudal em $P$. franciscoensis), terceiro infra-orbital separado da margem horizontal do préopérculo por um espaço de $1 / 5$ a $1 / 7$ do seu comprimento (vs 1 / 3 a 1/4, raramente $1 / 5$ em $P$. jancupa), mancha umeral arredondada e uniformemente pigmentada ( $v s$ mancha umeral verticalmente alongada, coloração difusa na parte superior em $P$. maculoblongus), focinho abrupto ( $v$ s focinho afilado em $P$. simulatus), mancha umeral localizada mais próxima do pseudotímpano, acima da quinta ou sexta a sétima escamas da linha lateral ( $v s$ acima da sexta a oitava em $P$. simulatus), área nua relativamente estreita entre a margem inferior do terceiro infra-orbital e a margem horizontal do pré-opérculo, 7,4-10 vezes no diâmetro horizontal da órbita ( $v s$ área nua ampla, 4,9-6,5 vezes no diâmetro horizontal da órbita em $P$. simulatus), diâmetro orbital de $38,1-45,7 \%$ no CC (33,0-36,9\% em P. ojitatus), espécimes machos com pequeníssimos ganchos nas nadadeiras peitorais (ausentes em $P$. calverti, $P$. franciscoensis, $P$. jancupa, $P$. wayampi e $P$. wayana) e ganchos nas nadadeiras pélvicas (ausentes em P. carteri, P. napoatilis).

Descrição. Dados morfométricos na tabela VI. Corpo comprimido, comparativamente baixo, perfil dorsal convexo do focinho até a origem da nadadeira dorsal, raramente reto na região imediatamente à frente do processo supra-occipital; declinando-se e tornando-se reto desde a origem da nadadeira 


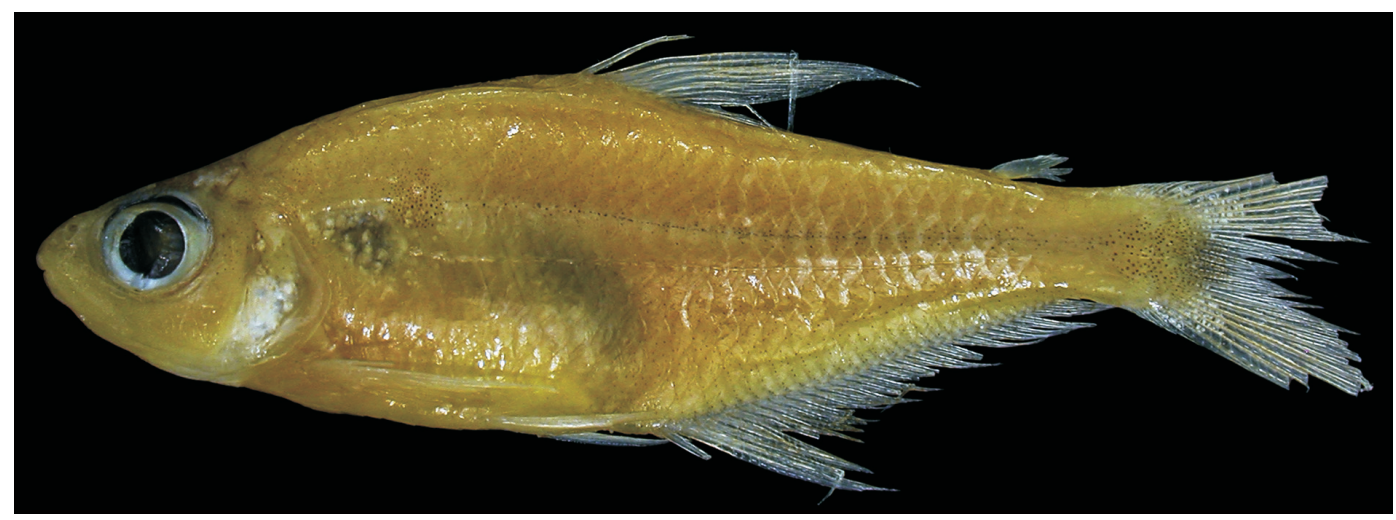

Figura 10. Phenacogaster retropinnus sp. nov., INPA 31367, holótipo, 40,0 mm CP, Rio Aripuanã, sistema do Rio Madeira, Mato Grosso.

Tabela VI. Medidas de P. retropinnus sp. nov., holótipo INPA 31367. (n) Número de exemplares, incluindo o holótipo.

\begin{tabular}{|c|c|c|c|c|c|c|c|c|c|}
\hline \multirow{2}{*}{ Medidas } & \multirow{2}{*}{ Holótipo } & \multicolumn{4}{|c|}{ Limites material-tipo } & \multicolumn{4}{|c|}{ Limites material não-tipo } \\
\hline & & $\mathrm{n}$ & Mínimo & Máximo & Média & $\mathrm{n}$ & Mínimo & Máximo & Média \\
\hline Comprimento padrão (mm) & 40,0 & 23 & 24,0 & 40,6 & 34,7 & 28 & 25,5 & 40,6 & 33,0 \\
\hline \multicolumn{10}{|c|}{ Porcentagens do comprimento padrão } \\
\hline Altura do corpo & 31,7 & 24 & 26,5 & 31,8 & 29,2 & 28 & 25,1 & 32,8 & 29,6 \\
\hline Comprimento pré-dorsal & 48,0 & 24 & 47,6 & 51,6 & 49,4 & 28 & 46,7 & 52,3 & 49,7 \\
\hline Comprimento pré-ventral & 40,7 & 24 & 37,1 & 51,6 & 40,0 & 28 & 39,0 & 43,7 & 40,8 \\
\hline Comprimento pré-anal & 53,5 & 24 & 52,6 & 56,3 & 54,7 & 28 & 52,9 & 58,7 & 55,8 \\
\hline Comprimento ped. caudal & 8,0 & 24 & 8,5 & 11,5 & 9,7 & 28 & 8,3 & 10,7 & 9,2 \\
\hline Altura ped. caudal & 9,0 & 24 & 7,6 & 10,0 & 8,8 & 28 & 7,2 & 9,6 & 8,1 \\
\hline Comprimento nad. peitoral & 21,7 & 24 & 20,1 & 26,9 & 22,5 & 28 & 17,3 & 23,9 & 21,1 \\
\hline Comprimento nad. pélvica & 17,2 & 24 & 16,6 & 20,2 & 17,6 & 28 & 17,3 & 20,0 & 18,7 \\
\hline Distância peitoral-pélvica & 12,7 & 24 & 10,6 & 12,9 & 11,8 & 28 & 9,8 & 13,5 & 12,1 \\
\hline Distância pélvica-anal & 12,7 & 24 & 9,2 & 13,6 & 11,9 & 28 & 10,6 & 13,3 & 10,8 \\
\hline Dist. occipital-dorsal & 24,7 & 24 & 23,6 & 26,2 & 25,1 & 28 & 19,6 & 28,4 & 24,7 \\
\hline Distância dorsal-adiposa & 26,0 & 24 & 24,3 & 29,9 & 26,5 & 28 & 23,5 & 27,2 & 26,0 \\
\hline Comprimento cabeça & 28,7 & 24 & 24,4 & 28,7 & 25,8 & 28 & 25,3 & 29,1 & 26,4 \\
\hline Comprimento focinho & 6,7 & 24 & 6,3 & 7,6 & 6,9 & 28 & 6,0 & 7,7 & 6,7 \\
\hline Comprimento maxilar & 6,2 & 24 & 5,9 & 7,1 & 6,4 & 28 & 6,5 & 7,5 & 7,0 \\
\hline Espaço interorbital & 6,0 & 23 & 5,6 & 7,5 & 6,3 & 28 & 5,4 & 6,8 & 6,2 \\
\hline Diâmetro órbita & 10,7 & 24 & 9,9 & 11,9 & 10,7 & 28 & 10,3 & 11,8 & 11,1 \\
\hline \multicolumn{10}{|c|}{ Porcentagens do comprimento da cabeça } \\
\hline Comprimento focinho & 23,5 & 24 & 23,5 & 29,8 & 26,8 & 28 & 22,6 & 29,2 & 25,5 \\
\hline Diâmetro órbita & 37,4 & 24 & 39,3 & 45,7 & 41,5 & 28 & 38,1 & 44,8 & 42,0 \\
\hline Espaço interorbital & 21,6 & 23 & 21,6 & 26,8 & 24,5 & 28 & 21,0 & 25,4 & 23,5 \\
\hline Comprimento maxilar & 21,7 & 24 & 22,1 & 27,4 & 25,0 & 28 & 24,1 & 29,5 & 26,4 \\
\hline
\end{tabular}


dorsal até o final do pedúnculo caudal; reto ou levemente côncavo no pedúnculo caudal. Perfil ventral do corpo levemente convexo ou quase reto da extremidade da mandíbula até a origem da nadadeira anal, elevando-se e continuando reto ou levemente convexo ao longo da base da nadadeira anal e reto ou levemente côncavo no pedúnculo caudal. Extremidade da maxila superior ultrapassa a ponta da mandíbula. Boca situada abaixo da linha mediana horizontal da órbita. Terceiro infraorbital com a margem inferior separada da margem horizontal do pré-opérculo por um espaço de aproximadamente 1/5 a 1/7 do seu comprimento; margem posterior separada da margem vertical do pré-opérculo por um espaço aproximadamente igual ou menor, podendo alcançar a margem do pré-opérculo. Duas fileiras de dentes no pré-maxilar, fileira externa interrompida com 3-7 dentes totais (quatro no lado esquerdo, cinco no direito do holótipo, média $=4,9$ ), sendo 2 -3 tricúspides na região medial, mais largos e maiores que os da região lateral e 1-3 cônicos menores e mais delgados na região lateral. Em alguns espécimes, um dos lados da fileira externa é continua, com 6-7 dentes (contada em dois parátipos) tricúspides anteriormente e cônicos posteriormente. Fileira interna com 7-9 dentes (nove no holótipo, média $=8,5 ; \mathrm{n}=52$ ) que decrescem em tamanho e largura, sendo os três primeiros tricúspides e geralmente maiores, seguidos de dentes tricúspides e cônicos, de modo que, aproximadamente, os últimos são sempre delgados e cônicos. Alguns espécimes com um dente cônico localizado na porção posterior do pré-maxilar, entre as fileiras externa e interna. Maxilar com 21-37 dentes cônicos (aproximadamente 28 no holótipo, média $=28,6 ; \mathrm{n}=61$ ) situados ao longo de quase toda a margem ventral do osso. Dentário com 14-19 dentes em uma única fileira, 4-6 dentes anteriores tricúspides e maiores (quatro em um parátipo) seguidos de 10-13 cônicos ou com pequeníssimas cúspides menores e mais delgados. Nadadeira dorsal com ii, 9 raios. Origem da nadadeira dorsal localizada próxima à metade do corpo. Nadadeira anal com iii-iv,28-34 raios (iv,30 no holótipo, média $=30,8 ; \mathrm{n}=70$ ). Origem da nadadeira anal localizada na vertical que passa aproximadamente pela base do quinto ao sexto raio ramificado da nadadeira dorsal. Margem anterior da nadadeira anal côncava, o último raio ramificado e os cinco a seis primeiros ramificados maiores que os demais (os três primeiros aproximadamente do mesmo tamanho); uma bainha de aproximadamente nove escamas ao longo da base da nadadeira, que se estende até o sétimo raio ramificado. Nadadeiras peitorais com i,10-15 raios (13 no holótipo, 10 em um parátipo média $=13,1 ; \mathrm{n}=70$ ); extremidade posterior do raio mais longo ultrapassa a origem das nadadeiras pélvicas, não atingindo a metade dessas nadadeiras; raios das nadadeiras peitorais totalmente desenvolvidos em indivíduos a partir de 17,9 $\mathrm{mm}$ de $\mathrm{CP}$, parcialmente desenvolvidos em indivíduos de 17,5 mm de CP. Margem posterior do cleitro com ou sem reentrância. Nadadeiras pélvicas com i,7 raios, ultrapassam a origem da nadadeira anal, alcançando, no máximo, do primeiro ao terceiro raio ramificado da nadadeira anal (geralmente o primeiro, no sistema do Rio Madeira). Linha lateral com 37-39 escamas perfuradas (aproximadamente 38 no holótipo, média $=37,3 ; \mathrm{n}=28$ ). Cinco a seis fileiras de escamas entre a origem da nadadeira dorsal e a linha lateral (cinco no holótipo) e quatro a cinco entre a linha lateral e a origem da nadadeira anal (cinco no holótipo). Presença de uma escama sobreposta entre 1-7 pares de escamas pré-ventrais (cinco no holótipo), localizadas entre as origens das nadadeiras peitorais e pélvicas. Ramo superior do primeiro arco branquial com 4-6 rastros (cinco no holótipo, média $=4,5 ; \mathrm{n}=70$ ) e ramo inferior com 7-10 rastros (sete no holótipo, média $=8,8 ; \mathrm{n}=71$ ). Vértebras totais 35, pré-caudais 15 e caudais 20. Quatro supraneurais.

Coloração em álcool. A coloração geral do corpo é amarela. Região latero-dorsal com cromatóforos dispostos principalmente na borda das escamas. Região lateroventral entre a origem das nadadeiras peitorais ou das nadadeiras pélvicas até próximo à origem da nadadeira anal sem pigmentos, algumas vezes pouquíssimos e restritos próximo às nadadeiras peitorais. Região entre a linha lateral e a nadadeira anal com cromatóforos dispostos em forma de $>$, demarcando os mioseptos. Imediatamente acima da base da nadadeira anal, os cromatóforos situam-se transversalmente em relação ao eixo do corpo, no nível de cada raio da nadadeira. Opérculo com cromatóforos concentrados na região superior. Região dorsal da cabeça e dorso do corpo mais pigmentados que o restante do corpo; cromatóforos formando linhas sinuosas entre a região que se estende das narinas até o espaço interorbital. Mancha umeral arredondada a levemente alongada verticalmente, situada acima da quinta ou sexta à sétima escamas da linha lateral e geralmente desde a primeira até a terceira costela contada a partir do final do pseudotímpano. Seu comprimento horizontal é menor ou no máximo igual à metade do diâmetro horizontal da órbita. Uma faixa prateada presente no holótipo e parátipos (INPA 16191), estende-se na região médio-lateral do corpo, desde a região imediatamente após o pseudotímpano até o pedúnculo caudal. Nos demais lotes, há, em geral, uma faixa clara situada na mesma posição dessa faixa. Uma linha escura situada sobre essa faixa estende-se desde a região após o pseudotímpano - geralmente mais conspícua na vertical, que passa pela origem da nadadeira dorsal - até o início da mancha do pedúnculo caudal. Pedúnculo caudal com uma mancha triangular que se prolonga além da base e entre os raios medianos da nadadeira caudal. Nadadeira dorsal com pigmentos expandidos nas membranas inter-radiais, principalmente no terço superior da nadadeira até, aproximadamente, o quinto raio ramificado; margem posterior de cada raio, escura; primeiro raio não-ramificado mais pigmentado que os demais. Nadadeiras peitorais e pélvicas com pigmentos dispostos ao longo das margens; primeiro raio das nadadeiras peitorais mais pigmentado (nadadeiras claras nos espécimes nãotipo do Rio Negro). Nadadeira anal totalmente pigmentada até, aproximadamente, o sétimo raio ramificado, a partir daí a pigmentação restringe-se à base e à margem da nadadeira, de modo a deixar uma região clara mediana ao longo da nadadeira. No 
holótipo e em alguns parátipos, a nadadeira anal é totalmente pigmentada, embora na região mediana os pigmentos sejam menores e relativamente mais fracos. Nadadeira caudal com pigmentos dispostos ao longo dos raios; região mediana clara, imediatamente após a mancha, geralmente com pigmentos somente na borda.

Dimorfismo sexual. Foram examinados 22 machos, medindo de 24,2 a 37,5 mm de CP (INPA 16184, INPA 16187, INPA 16191, MCP 43596). Apresentam ganchos sobre as nadadeiras anal, pélvicas e peitorais. Os menores machos foram encontrados no sistema do Rio Madeira (INPA 16187), cujos ganchos já se encontram bem desenvolvidos em indivíduos a partir de $24 \mathrm{~mm}$ de CP. Nos demais lotes, os ganchos estão presentes apenas em indivíduos acima de 30,0 $\mathrm{mm}$ de CP (31,9 a 40,4 mm de CP). Nos parátipos do lote INPA 16191, a nadadeira anal possui ganchos retrorsos diminutos ou protuberâncias desde o primeiro ao quinto raio, sexto, raramente sétimo ramificado, na região póstero-lateral do segundo ramo, um gancho, raramente dois por segmento de raio, e as nadadeiras pélvicas possuem protuberâncias ou ganchos que podem estar situados desde o primeiro raio ramificado ao penúltimo, dispostos, medialmente, no segundo ramo, um gancho por segmento. Ganchos nas nadadeiras peitorais, visualizados somente em material clarificado e corado, diminutos e dispostos ao longo da margem dorsal do segundo raio ramificado.

Material examinado. Holótipo. Brasil, Mato Grosso: Rio Aripuanã (3 km abaixo da cachoeira Dardanelos, sistema do Rio Madeira), 7/XI/1976, equipe de ictiologia do INPA leg., INPA 31367 (40,0 mm CP). Parátipos. Brasil, Mato Grosso: Rio Aripuanã (3 km abaixo da cachoeira Dardanelos, sistema do Rio Madeira), 7/XI/1976, equipe de ictiologia do INPA leg., coletados juntamente com o holótipo, INPA 16191 (33, 30,740,6 mm CP, 1 d\&c 39,0 mm CP), MCP 43596 (6, 34-39,6 mm CP, 1 d\&c 37,2 mm CP). Rondônia: Rio Jamari (Ariquemes, sistema do Rio Madeira), 14/IX/1985, G. Mendes leg., INPA 16184 (49, 22,8-36,6 mm CP); Rio Machado (Jiparaná, Nazaré), 9/IX/ 1983, G. Mendes leg., INPA 16187 (8, 22,7-30,3 mm CP). Nãotipos. BrasiL, Amazonas: Rio Negro (Camanaos), 22/I/1925, ANSP 149958 (15, 31,2-40,6 mm CP); Rio Marauiá (próximo à foz), X/1979, MZUSP 29399 (1, 27,2 mm CP); Rio Negro (logo abaixo do Rio Daraá), 16/II/1980, MZUSP 29400 (3, 31,8-32,2 mm CP); Rio Negro (Marauiá), X/1979, MCP 43786 (2, 30,1-30,9 mm CP), MZUSP 29402 (10, 25,5-31,9 mm CP); Rio Tiquié, (comunidade de Caruru, sistema do Rio Negro, $0^{\circ} 16^{\prime} 27^{\prime \prime} \mathrm{N}$ $\left.69^{\circ} 54^{\prime} 56^{\prime \prime} \mathrm{W}\right), \mathrm{V} / 2000$, MZUSP 64932 (1, 51,2 mm CP); Rio Tiquié (poço abaixo da cachoeira do Caruru, comunidade de Caruru, sistema do Rio Negro, 0¹6'27"N 6954'56”W), 24/X/ 2000, MZUSP 66139 (1, 48,8 mm CP); Rio Tiquié (poço após a cachoeira do Caruru, sistema do Rio Negro, comunidade de Caruru, $0^{\circ} 16^{\prime} 27^{\prime \prime} \mathrm{N} 65^{\circ} 54^{\prime} 56^{\prime \prime} \mathrm{W}$ ), 21/X/2000, MZUSP 66655 (2 de 6, 37,5-41,2 mm CP). Mato Grosso: Rio Xingu (encontro com os rios Culuene e Sete de Setembro), 23/VIII/1984, MZUSP 30550 (12, 18,5-30,5 mm CP); Pará: Rio Xingu (Cachoeira do Espe- lho), 23-26/X/1986, MZUSP 36811 (5, 19,8-33,2 mm CP). Distribuição. Sistemas do rios Negro, Madeira e Xingu (Fig. 3).

Etimologia. Do latim retro, em direção posterior; e pinnus, nadadeira. Em alusão à posição relativamente posterior da nadadeira anal.

Comentários. Phenacogaster retropinnus é uma espécie que apresenta o corpo comparativamente baixo (25,1-32,8\% do CP, $\mathrm{n}=68$ ), tanto em fêmeas quanto em machos, e é diferenciada da maioria das demais espécies pela altura, a qual geralmente ultrapassa $32,8 \%$ do CP, podendo chegar a 40,1\% em $P$. franciscoensis. Entretanto, um único espécime não-tipo (o maior examinado, 51,0 mm CP) proveniente do Rio Tiquié, sistema do Rio Negro, é relativamente mais alto, com a altura do corpo $34,4 \%$ do CP. A ausência de ganchos e a dilatação da região ventral indicam que pode tratar-se de uma fêmea em época de reprodução. No material não-tipo, a faixa prateada que se estende na região médiolateral do corpo, desde a região imediatamente após o pseudotímpano até o pedúnculo caudal, está presente nos espécimes do Rio Negro do lote ANSP 149958. Nos demais lotes nãotipos, há, em geral, uma faixa clara situada na mesma posição dessa faixa.

\section{Phenacogaster simulatus sp. nov.} Fig. 11

Diagnose. Phenacogaster simulatus difere das espécies do complexo $P$. pectinatus pela presença de conspícua mancha umeral em machos e fêmeas (vs mancha umeral, em machos, ausente ou restrita a poucos cromatóforos), conspícua mancha no pedúnculo caudal ( $v s$ ausente ou restrita a poucos cromatóforos) e maior comprimento pré-anal (51,5-56,8 vs 45,1$52,5)$. Diferencia-se das demais espécies pela presença de pequeníssimos ganchos adicionais na porção distal dos raios da nadadeira anal dos machos ( $v s$ ausentes nas demais, exceto em P. maculoblongus). Difere de P. maculoblongus por apresentar mancha umeral arredondada ou semicircular ( $v s$ verticalmente alongada) e menor espaço interorbital em espécimes machos acima de $30 \mathrm{~mm}$ de CP (22,0-25,7\% vs 24,7-29,3\% no CC em $P$. maculoblongus). Diferencia-se de $P$. retropinnus por apresentar o focinho afilado ( $v s$ abrupto), a mancha umeral localizada mais posteriormente, acima da sexta a oitava escamas da linha lateral ( $v s$ acima da quinta ou sexta a sétima), e uma ampla área nua entre a margem inferior do terceiro infra-orbital e a margem horizontal do pré-opérculo, 4,9-6,5 vezes no diâmetro horizontal da órbita ( $v s$ área nua estreita, 7,4-10 vezes no diâmetro horizontal da órbita). Phenacogaster simulatus também pode ser diferenciada por apresentar corpo baixo, maior altura $27,3-31,7 \%$ vs 31,0 a 40,1\% no CP de P. capitulatus, $P$. franciscoensis, P. napoatilis, $P$. ojitatus e P.tegatus, em espécimes acima de $30 \mathrm{~mm}$ de CP; por apresentar a linha lateral completa ( $v s$ incompleta em P. capitulatus, $P$. carteri, $P$. napoatilis e $P$. tegatus); mancha umeral grande e conspícua em machos e fêmeas ( $v s$ ausente em $P$. 


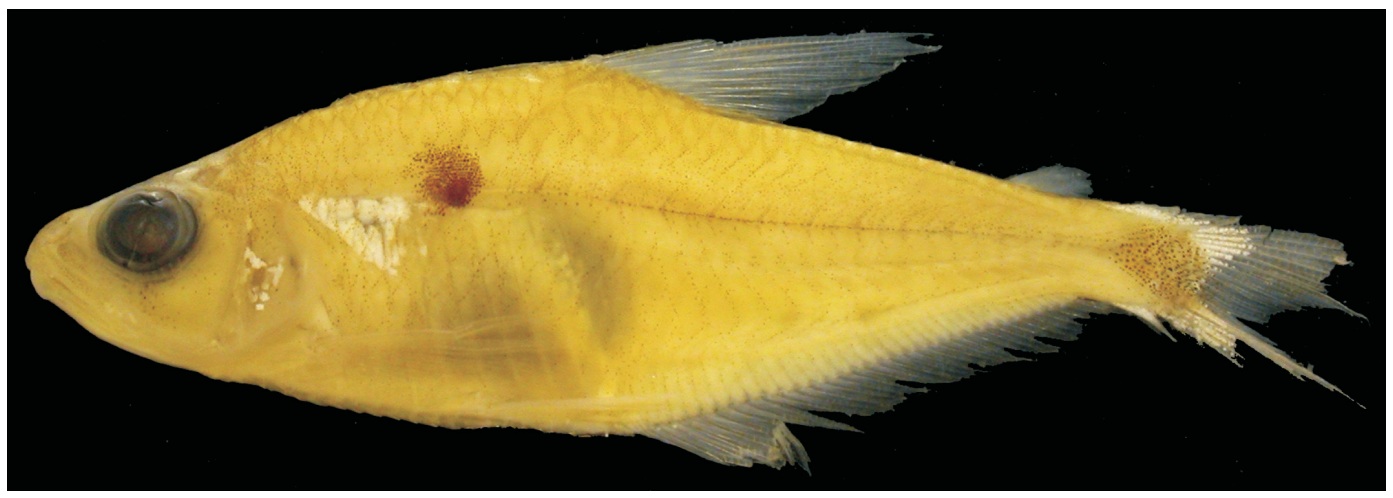

Figura 11. Phenacogaster simulatus sp. nov., ROM 72774, holótipo, 43,2 mm CP, Rio Potaro, Guiana.

capitulatus, P. carteri e em machos de P. napoatilis); mancha umeral situada mais próxima do pseudotímpano do que da vertical que passa pela origem da nadadeira dorsal (vs mancha umeral na vertical que passa imediatamente à frente ou na origem da nadadeira dorsal em $P$. tegatus); mancha no pedúnculo caudal presente (ausente em $P$. carteri e $P$. prolatus), mancha do pedúnculo caudal triangular, seu limite anterior não alcançando a vertical que passa pela extremidade posterior da nadadeira adiposa ( $v s$ losangular, seu limite anterior alcançando ou ultrapassando a extremidade posterior da nadadeira adiposa em $P$. wayampi), 3135 (média 32,9) raios ramificados na nadadeira anal (vs 27-32 em $P$. calverti, média 29,5 e em $P$. franciscoensis, média 29,7), maior comprimento da cabeça em espécimes acima de $30 \mathrm{~mm}$ de $\mathrm{CP}$ (25,3-28,0\% no CP vs 21,5-24,5\% em P. capitulatus e 23,2-25,9\% em $P$. napoatilis), comprimento do maxilar $24,5-28,9 \%$ no CC (vs 29,3-35\% em P. prolatus), espaço interorbital estreito (21,326,1\% do CP vs 25,3-30,7 em P. carteri, P. franciscoensis, P. jancupa, $P$. napoatilis, $P$. ojitatus e $P$. wayampi, em espécimes acima de 30 mm CP), comprimento pré-ventral (38,0-43,4\% no CP vs 35,4$38,9 \%$ em $P$. carteri) e ganchos presentes nas nadadeiras peitorais dos machos, dispostos ventralmente na porção distal do ramo ventral dos raios ramificados ( $v s$ ausentes em $P$. calverti, $P$. franciscoensis, P. jancupa, P. maculoblongus, P. wayampi, P. wayana; presentes, mas dispostos distintamente em $P$. capitulatus, $P$. carteri, P. megalostictus, P. napoatilis, P. retropinnus). Phenacogaster simulatus apresenta a maioria dos caracteres merísticos e morfométricos semelhante a $P$. megalostictus, espécie que também ocorre no sistema do Rio Essequibo, e sintópica com $P$. simulatus, no Rio Potaro. Entretanto, os seguintes caracteres diferenciam essa espécie de $P$. megalostictus: intervalo entre os dentes da série externa do pré-maxilar (2-7, média $=4,9$ vs completa com 5-10 dentes, média $=7,4$, em $P$. megalostictus), maior contagem do número de dentes no maxilar (25-32, média $=29,5$ vs 9-21, média $=$ 16), dentes do maxilar dispostos até aproximadamente a extremidade posterior do maxilar ( $v s$ aproximadamente até a metade), menor diâmetro orbital (10,1-11,9\% vs 10,5-14,4\% no CP, Fig. 12) e menor altura do corpo $(27,3-31,7 \%$ vs $30,4-38,4 \%$ no $\mathrm{CP}$ em indivíduos maiores que $30 \mathrm{~mm}$ de $\mathrm{CP}$ ).
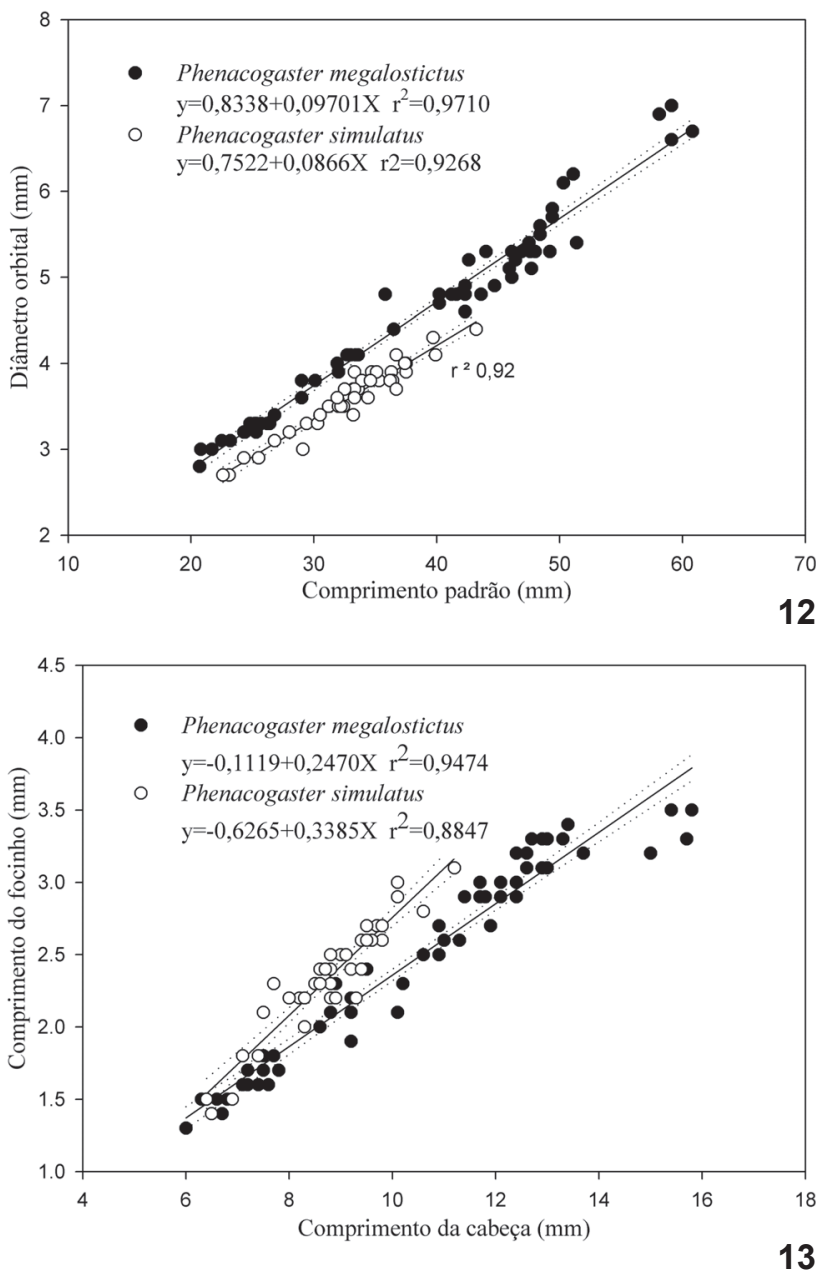

Figuras 12-13. (12) Regressão linear do diâmetro orbital sobre o comprimento padrão em Phenacogaster megalostictus e P. simulatus; (13) regressão linear do comprimento do focinho sobre o comprimento da cabeça em P. megalostictus e P. simulatus. Linhas tracejadas indicam o intervalo de confiança de $95 \%$. 
Tabela VII. Medidas de P. simulatus sp. nov., holótipo ROM 72774. (n) Número de exemplares, incluindo o holótipo.

\begin{tabular}{|c|c|c|c|c|c|}
\hline \multirow{2}{*}{ Medidas } & \multirow{2}{*}{ Holótipo } & \multicolumn{4}{|c|}{ Limites } \\
\hline & & $\mathrm{n}$ & Mínimo & Máximo & Média \\
\hline Comprimento padrão (mm) & 43,2 & 40 & 22,6 & 43,2 & 33,0 \\
\hline \multicolumn{6}{|c|}{ Porcentagens do comprimento padrão } \\
\hline Altura do corpo & 31,7 & 40 & 26,4 & 31,7 & 28,9 \\
\hline Comprimento pré-dorsal & 49,3 & 40 & 46,5 & 52,7 & 49,5 \\
\hline Comprimento pré-ventral & 40,3 & 36 & 38,0 & 43,4 & 40,2 \\
\hline Comprimento pré-anal & 53,2 & 40 & 51,5 & 56,8 & 54,3 \\
\hline Comprimento ped. caudal & 7,9 & 40 & 6,8 & 10,8 & 8,9 \\
\hline Altura ped. caudal & 8,3 & 40 & 7,0 & 9,6 & 8,3 \\
\hline Comprimento nad. peitoral & 23,8 & 34 & 20,4 & 24,8 & 22,6 \\
\hline Comprimento nad. pélvica & 18,3 & 35 & 16,4 & 21,3 & 18,0 \\
\hline Distância peitoral-pélvica & 11,3 & 36 & 8,3 & 12,2 & 11,0 \\
\hline Distância pélvica-anal & 11,3 & 36 & 10,7 & 12,8 & 11,5 \\
\hline Dist. occipital-dorsal & 24,1 & 36 & 23,4 & 26,9 & 24,5 \\
\hline Distância. dorsal-adiposa & 26,6 & 36 & 24,1 & 28,1 & 26,3 \\
\hline Comprimento cabeça & 25,9 & 40 & 25,3 & 28,8 & 26,8 \\
\hline Comprimento focinho & 7,1 & 40 & 6,2 & 7,9 & 7,1 \\
\hline Comprimento maxilar & 6,7 & 40 & 6,4 & 7,5 & 7,0 \\
\hline Espaço interorbital & 5,8 & 40 & 5,7 & 8,0 & 6,4 \\
\hline Diâmetro órbita & 10,2 & 40 & 10,1 & 11,9 & 11,0 \\
\hline \multicolumn{6}{|c|}{ Porcentagens do comprimento da cabeça } \\
\hline Comprimento focinho & 27,7 & 40 & 21,5 & 29,9 & 26,6 \\
\hline Diâmetro órbita & 39,3 & 40 & 38,9 & 44,3 & 41,0 \\
\hline Comprimento maxilar & 25,9 & 40 & 24,5 & 28,9 & 26,0 \\
\hline Espaço interorbital & 22,3 & 40 & 21,3 & 27,7 & 23,9 \\
\hline
\end{tabular}

Descrição. Dados morfométricos na tabela VII. Corpo comprimido, perfil dorsal levemente convexo desde o focinho até a base do processo supra-occipital algumas vezes levemente côncavo imediatamente à frente da base do processo supraoccipital, elevando-se suavemente e continuando convexo da base do processo occipital até a origem da nadadeira dorsal; declinando-se e tornando-se reto desde a origem da nadadeira dorsal até o fim do pedúnculo caudal. Perfil ventral do corpo levemente convexo da extremidade da mandíbula até a origem das nadadeiras pélvicas, e retilíneo deste ponto até a origem da nadadeira anal; elevando-se e continuando reto ao longo da base da nadadeira anal e reto ou levemente côncavo no pedúnculo caudal. A extremidade da maxila superior ultrapassa a ponta da mandíbula. Boca situada abaixo da linha mediana horizontal da órbita. Terceiro infra-orbital relativamente pequeno, margem ventral separada da margem horizontal do pré-opérculo por um espaço de aproximadamente $1 / 5$ a $1 / 6$ do seu comprimento (1/7 em um único indivíduo), aumentando em direção posterior de modo a deixar uma ampla área nua; margem posterior separada da margem vertical do pré-opérculo por um espaço pouco menor ou quase sem espaço. Duas fileiras de dentes no pré-maxilar, fileira externa interrompida, com 2-7 dentes totais (cinco no holótipo, dois e sete em um único espécime, média $=4,9 \mathrm{n}=34$ ), sendo dois ou três dentes tricúspides na região medial, maiores que os demais e 1-4 dentes cônicos (em alguns o primeiro possui duas cúspides) mais estreitos na região lateral (um espécime sem dentes). Fileira interna com 7-10 dentes (oito no holótipo, média $=8,4 ; \mathrm{n}=$ $23)$, sendo três ou quatro tricúspides relativamente maiores e mais largos seguidos de 3-6 tricúspides e cônicos menores e mais estreitos. Alguns espécimes possuem um dente cônico localizado na porção posterior do pré-maxilar, entre as fileiras externa e interna. Maxilar com 25-32 dentes cônicos (31 no holótipo, média $=29,4 ; \mathrm{n}=20$ ) situados ao longo de quase 
toda a margem ventral. Dentário com 15 a 16 dentes (contados em dois espécimes), os cinco primeiros tricúspides seguidos de dentes cônicos menores e mais estreitos. Nadadeira dorsal com ii,9 raios (oito em um único espécime). Origem da nadadeira dorsal localizada próxima à metade do corpo. Nadadeira anal com iii-iv,31-35 raios (32 no holótipo, média $=32,9 ; \mathrm{n}=40$ ). Origem da nadadeira anal localizada na vertical que passa pela base do quarto ao quinto raio ramificado da nadadeira dorsal. Margem da nadadeira anal levemente côncava, com o último raio não-ramificado e os quatro a cinco primeiros ramificados maiores que os demais (os três primeiros ramificados aproximadamente do mesmo tamanho); uma bainha de escamas se estende ao longo da base da nadadeira anal até, pelo menos, o sexto raio ramificado. Nadadeiras peitorais com i,10-15 raios (13 no holótipo, 11 e 10 em um exemplar, média = 12,7; $\mathrm{n}=$ 39 ), extremidade posterior do raio mais longo ultrapassa a origem das nadadeiras pélvicas, atingindo a metade ou aproximadamente a metade dessas nadadeiras; raios totalmente desenvolvidos nos menores indivíduos examinados, 22,6 e 23,1 mm de CP. Margem posterior do cleitro com ou sem reentrância, a qual pode ser leve ou acentuada. Nadadeiras pélvicas, com i,7 raios, ultrapassam a origem da nadadeira anal, atingindo o segundo ou terceiro raio ramificado dessa nadadeira. Linha lateral com 36-38 escamas perfuradas (contagem aproximada, exceto em um espécime com 38). Seis fileiras de escamas entre a origem da nadadeira dorsal e a linha lateral; cinco fileiras entre a linha lateral e a origem da nadadeira anal. Presença de uma única escama sobreposta entre 2-6 pares de escamas préventrais, localizadas entre as origens das nadadeiras peitorais e pélvicas. Ramo superior do primeiro arco branquial com 4-6 rastros (cinco no holótipo, média $=4,8 ; \mathrm{n}=40$ ) e ramo inferior com 8-10 (nove no holótipo, média $=9,1 ; \mathrm{n}=40$ ). Vértebras totais 35 , pré-caudais 15 , caudais 20 . Quatro supraneurais.

Coloração em álcool. A coloração geral do corpo é amarela. Região laterodorsal com cromatóforos dispostos principalmente na borda das escamas. Região lateroventral entre as nadadeiras peitorais e a origem da nadadeira anal é basicamente desprovida de pigmentação em espécimes menores que $34,0 \mathrm{~mm}$ de CP, aproximadamente. Na região entre a linha lateral e a nadadeira anal, os cromatóforos dispõem-se em forma de $>$, demarcando os mioseptos. Região dorsal da cabeça e dorso do corpo intensamente pigmentados podendo formar, no focinho e parte anterior do espaço interorbital, linhas simétricas e sinuosas. Opérculo com pigmentos concentrados na região superior e mediana, estendendo-se além da metade do osso. Mancha umeral conspícua circular ou semicircular, geralmente mais difusa na metade superior; situada principalmente acima da sexta a oitava escamas da linha lateral (sobre parte superior da linha lateral em um único espécime) e entre a segunda e a quinta costelas contadas a partir do pseudotímpano. Seu comprimento horizontal é aproximadamente igual ou menor que a metade do diâmetro orbital. Área ao redor da mancha umeral, despigmentada. Uma linha escura, situada na região médio-lateral do corpo, acima da linha lateral, estende-se desde a região um pouco atrás da mancha umeral até a mancha do pedúnculo caudal. Imediatamente acima e ao longo dessa linha dispõe-se uma faixa de cromatóforos e, abaixo, na região imediatamente acima da linha lateral, uma faixa clara, quase desprovida de pigmentação. Escamas da linha lateral com dois cromatóforos dispostos verticalmente na região posterior. Pedúnculo caudal com uma conspícua mancha triangular, em machos e fêmeas, que se prolonga pouco além da porção basal, mas não até o final dos raios medianos da nadadeira caudal. Nadadeira caudal com pigmentos esparsos, com os raios medianos (exceto a região basal) claros, não-pigmentados. Nadadeira dorsal com pigmentos ao longo das margens anterior e posterior das membranas inter-radiais, exceto na região mais basal, onde apresenta pigmentos menores ao longo da porção posterior de cada raio; primeiro raio não-ramificado da nadadeira dorsal pigmentado. Nadadeiras peitorais com pigmentos situados, principalmente, ao longo da porção posterior dos raios; porção mais distal dos raios clara. Na maioria dos espécimes, os três últimos raios são claros. Nadadeiras pélvicas com pigmentos ao longo das margens anterior e posterior dos raios; a coloração é mais escura próximo à base dos raios, tornando-se intermediária na porção mediana da nadadeira, e mais clara na porção mais distal. Nadadeira anal com a base dos raios quase desprovida de pigmentação e a extremidade mais escura, de modo a formar uma região clara na porção mediana da nadadeira, aproximadamente, a partir do quarto ou quinto raio ramificado; pterigióforos da nadadeira anal bem demarcados por cromatóforos.

Dimorfismo sexual. Foram examinados 15 machos, medindo de 31,9 a 39,9 mm de CP (MCP 29197, MCP 29198, ROM 61469). Apresentam ganchos nas nadadeiras peitorais, pélvicas e anal. Nadadeira anal com ganchos reduzidos que podem estar situados do primeiro ao quinto raio ramificado, dispostos posteriormente no segundo ramo; um espécime com dois ganchos diminutos no oitavo raio ramificado; um ou dois ganchos por segmento; nadadeiras pélvicas com ganchos retrorsos ou nódulos, desde o primeiro ou segundo até o quinto, raramente até o sexto raio ramificado, dispostos medialmente no segundo ramo, com um gancho por segmento. Peitorais com um nódulo no quarto raio ramificado de um único espécime e ganchos diminutos visualizados em outro espécime, situados ventralmente na porção distal do ramo ventral do sexto e sétimo raios ramificados da nadadeira direita. Machos apresentam pequeníssimos ganchos na porção distal dos ramos anterior e posterior dos raios ramificados da nadadeira anal, visualizados somente em espécimes clarificados e corados.

Material examinado. Holótipo. Guiana, Potaro-Siparuni: Tukeit Falls (Rio Potaro, Mahdia 05²'18”N 59²6'55”W), 26/ IX/1990, E. Holm et al. leg., ROM 72774 (43,2 mm CP). Parátipos. Guiana, Potaro-Siparuni: Rio Potaro (em Waratuk, norte de Portage, Mahdia, $\left.05^{\circ} 17^{\prime} 00^{\prime \prime} \mathrm{N} 59^{\circ} 22^{\prime} 00^{\prime \prime} \mathrm{W}\right), 1 / \mathrm{X} / 1990$, E. Holm \& M. Kelly leg., ANSP 170210 (4, 22,6-25,5 mm CP); Amatuk Falls (canal lateral do Rio Potaro, próximo a Portage, $05^{\circ} 18^{\prime} 00^{\prime \prime} \mathrm{N}$ 
59¹8'00”W), 3/X/1990, E. Holm leg., MCP 29197 (2, 26,8-39,9 mm CP); Rio Potaro (logo abaixo de Tukeit Falls, 05 $12^{\prime} 18^{\prime \prime} \mathrm{N}$ 59²6'55”W), 29/IX/1990, E. Holm \& B. Howard leg., MCP 29198 (3, 28,0-33,3 mm CP; Amatuk Falls (canal lateral do Rio Potaro, próximo a Portage, $\left.05^{\circ} 18^{\prime} 00^{\prime \prime} \mathrm{N} 59^{\circ} 18^{\prime} 00^{\prime \prime} \mathrm{W}\right), 02 / \mathrm{X} / 1990$, E. Holm leg., MCP 33610 (1, 23,3 mm CP); Rio Potaro (Tukeit Falls,

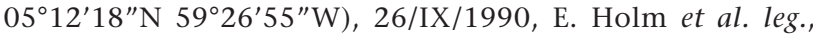
coletados juntamente com o holótipo, ROM 61469 (34, 24,737,5 mm CP, 2 d\&c, 31,9-36,8 mm CP).

Distribuição. Conhecida somente do Rio Potaro, sistema do Rio Essequibo (Fig. 3).

Etimologia. Do latim simulo, similaridade em aparência; atus, tendo a natureza de. Em alusão à semelhança com a espécie P. megalostictus.

Comentários. Phenacogaster simulatus pode distinguir-se de $P$. megalostictus também pelo maior comprimento do focinho, em indivíduos com o comprimento da cabeça acima de $10 \mathrm{~mm}$ (Fig. 13).

\section{Phenacogaster wayampi sp. nov. Le Bail \& Lucena} Figs 14-15

Phenacogaster aff. megalostictus - Géry et al., 1991: 42 (somente exemplares do sistema do Oiapoque; prancha XII, fig. 2). Planquette et al., 1996: 217 (figura).

Diagnose. Phenacogaster wayampi difere das demais espécies do gênero por apresentar a mancha do pedúnculo caudal alongada e estreita, com seu limite anterior alcançando ou ultrapassando a vertical que passa pela extremidade posterior da nadadeira adiposa. Nas demais espécies, a mancha, quando presente, é relativamente curta e mais larga, não alcançando a vertical que passa pela extremidade posterior da nadadeira adiposa.

Descrição. Dados morfométricos na tabela VIII. Corpo comprimido, perfil dorsal convexo desde o focinho até o final da região interorbital, elevando-se e continuando reto ou convexo até a base do processo supra-occipital; convexo da base do processo supra-occipital até a origem da nadadeira dorsal; declinando-se e tornando-se reto desde a origem da nadadeira dorsal até o fim do pedúnculo caudal; reto ou levemente convexo, ao longo da base da nadadeira dorsal. Perfil ventral do corpo levemente convexo da extremidade da mandíbula até a origem das nadadeiras pélvicas; reto entre a origem das pélvicas até a origem da nadadeira anal, elevando-se e continuando reto ao longo da base da nadadeira anal e reto no pedúnculo caudal. Extremidade da maxila superior situa-se no mesmo nível ou ultrapassa a ponta da mandíbula. Boca situada na linha mediana horizontal da órbita ou imediatamente abaixo. Terceiro infra-orbital relativamente grande; margem ventral separada da margem horizontal do pré-opérculo por um pequeno espaço de, aproximadamente, 1/6 a 1/7 do seu comprimento; margem posterior separada da margem vertical do pré-opérculo por um pequeno espaço nos menores indivíduos, quase sem espaço no maior indivíduo (holótipo). Margem póstero-ventral do terceiro infra- orbital contata ou quase contata o pré-opérculo. Duas fileiras de dentes no pré-maxilar; fileira externa interrompida (contínua no pré-maxilar esquerdo de dois parátipos), com 4-7 dentes totais (quatro no holótipo, nove em um único parátipo com a fileira do pré-maxilar esquerdo completa, média $=6 ; n=8$ ), sendo geralmente dois ou três dentes tricúspides, maiores e mais largos que os demais na seção medial (1 dente do lado direito em um único parátipo), e 2-5 cônicos, raramente tricúspides, mais delgados na região lateral. Fileira interna com 7-10 dentes (sete no holótipo, média $=8,4 ; \mathrm{n}=7$ ), os três ou quatro primeiros mais largos que os demais, geralmente todos tricúspides ou somente o último ou dois últimos cônicos. Geralmente possuem um dente cônico localizado na porção posterior do pré-maxilar, entre as fileiras externa e interna. Maxilar com 27-37 dentes cônicos ( 37 no holótipo, média $=32,8 ; \mathrm{n}=6$; contagem aproximada) situados ao longo de quase toda a margem ventral (segundo dente do maxilar direito do holótipo, tricúspide). Dentário com 15-18 dentes em uma única fileira $(n=3)$, seis tricúspides seguidos de 9-12 mais delgados (cônicos ou provavelmente com pequeníssimas cúspides). Nadadeira dorsal com ii,9 raios. Origem da nadadeira dorsal localizada próxima à metade do corpo. Nadadeira anal com iv,31-35 raios (35 no holótipo, iii em um único espécime, média $=32,3 ; \mathrm{n}=10$ ). Origem da nadadeira anal localizada na vertical que passa aproximadamente pela base do terceiro ou quarto raio ramificado da nadadeira dorsal. Margem anterior da nadadeira anal côncava, o último raio não-ramificado e os 4-6 primeiros ramificados maiores que os demais (os três primeiros ramificados aproximadamente do mesmo tamanho); uma bainha de nove escamas ao longo da base da nadadeira anal, do primeiro raio não-ramificado até, pelo menos, o sétimo raio ramificado. Nadadeiras peitorais com i,12 -14 raios (12 no holótipo, média $=13,1 ; \mathrm{n}=9$ ), extremidade posterior do raio mais longo ultrapassa a origem das nadadeiras pélvicas, não atingindo a metade da nadadeira, exceto em dois parátipos com cerca de $28 \mathrm{~mm}$ de $\mathrm{CP}$; raios não-desenvolvidos somente no menor espécime examinado de 14,3 mm de CP. Margem posterior do cleitro sem reentrância ou levemente ondulada. Nadadeiras pélvicas, com i,7 raios, ultrapassam a origem da nadadeira anal, atingindo o terceiro ou quarto raio ramificado. Linha lateral com 37 a 38 escamas perfuradas (37 no holótipo,; $\mathrm{n}=2$ ). Seis fileiras de escamas entre a origem da nadadeira dorsal e a linha lateral e quatro a cinco fileiras entre a linha lateral e a origem da nadadeira anal. Ausência ou presença de uma única escama sobreposta entre 3-5 pares de escamas pré-ventrais, localizadas entre as origens das nadadeiras peitorais e pélvicas. Ramo superior do primeiro arco branquial com 5-6 rastros (seis no holótipo) e ramo inferior com 9-10 (nove no holótipo, um espécime com oito, média $=9,1 ; n=9$ ). Vértebras totais 34 , précaudais 14 e caudais 20. Cinco supraneurais. Contagem baseada na radiografia do holótipo.

Coloração em álcool. A coloração geral do corpo é amarela. Região laterodorsal praticamente despigmentada ou com cromatóforos dispostos na borda das escamas ou demarcando 

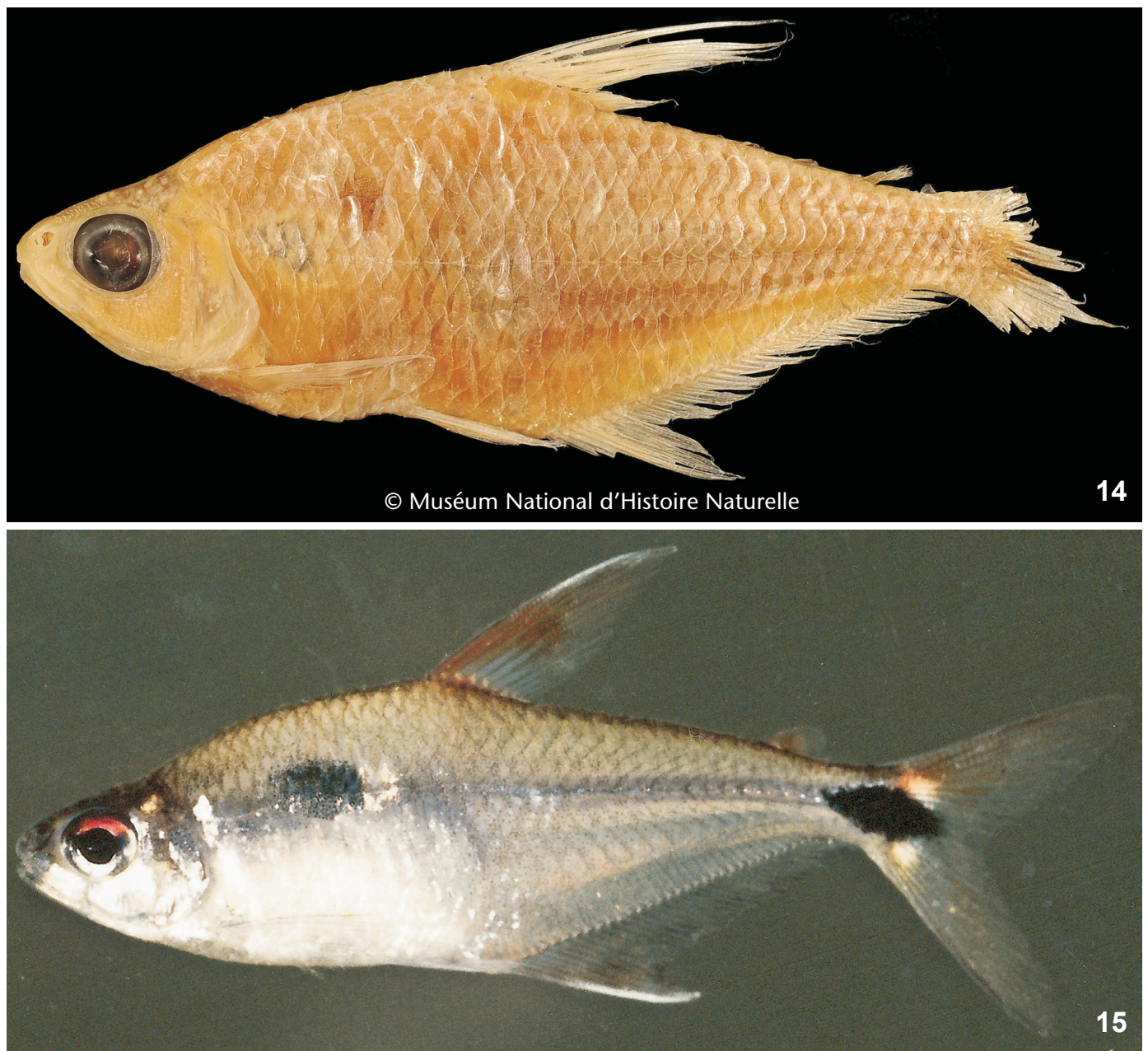

Figuras 14-15. Phenacogaster wayampi sp. nov.: (14) MNHN 1999-1457, holótipo, 47,6 mm CP, Rio Oiapoque, Guiana Francesa; (15) exemplar vivo capturado no Rio Oiapoque, Guiana Francesa. Foto P. Planquette.

parte dos mioseptos. Região lateroventral, abaixo da linha lateral, entre a origem das nadadeiras pélvicas e a da nadadeira anal praticamente despigmentada. Na região entre a linha lateral e a nadadeira anal os cromatóforos dispõem-se em forma de $>$, demarcando os mioseptos. Região dorsal do focinho e parte anterior do espaço interorbital com poucos pigmentos ou com cromatóforos dispostos em linhas simétricas e sinuosas. Dorso do corpo mais intensamente pigmentado que as demais regiões ou despigmentado. Opérculo pigmentado ou claro, com pigmentos concentrados na região superior. Acima das escamas da linha lateral, uma linha escura, horizontal, estende-se desde o final da mancha umeral até a mancha do pedúnculo caudal. Na maioria das vezes há uma área clara entre o final da mancha umeral e o início dessa linha escura, a qual pode se iniciar, também, na vertical que passa pelo segundo raio ramificado da nadadeira dorsal. Mancha umeral gran- de, seu comprimento horizontal é maior que a metade do diâmetro orbital (igual em um único espécime), obliquamente ou horizontalmente ovalada; situa-se acima da quinta ou sexta à oitava ou nona escamas da linha lateral e imediatamente após a primeira ou desde a segunda até á quarta ou quinta vértebra contada a partir do pseudotímpano (da terceira à quarta em um único parátipo, provavelmente despigmentada anteriormente). A parte mais posterior da mancha situa-se imediatamente acima da linha lateral (sobre uma pequeníssima parte, no holótipo), a anterior, uma ou meia escama acima da linha lateral. Pedúnculo caudal com uma conspícua mancha alongada, estreita e afilada anteriormente, em machos e fêmeas que se estende desde a vertical que passa à frente ou na extremidade posterior da nadadeira adiposa até os raios medianos da nadadeira caudal. Nadadeira dorsal com pigmentos ao longo das margens anterior e posterior dos raios ramificados, 
Tabela VIII. Medidas de P. wayampi sp. nov., holótipo MNHN 1999-1457. (n) Número de exemplares, incluindo o holótipo.

\begin{tabular}{|c|c|c|c|c|c|}
\hline \multirow{2}{*}{ Medidas } & \multirow{2}{*}{ Holótipo } & \multicolumn{4}{|c|}{ Limites } \\
\hline & & $\mathrm{n}$ & Mínimo & Máximo & Média \\
\hline Comprimento padrão (mm) & 47,6 & 8 & 28,9 & 47,6 & 34,9 \\
\hline \multicolumn{6}{|c|}{ Porcentagens do comprimento padrão } \\
\hline Altura do corpo & 36,8 & 8 & 30,8 & 36,8 & 32,5 \\
\hline Comprimento pré-dorsal & 49,1 & 8 & 48,5 & 51,6 & 49,9 \\
\hline Comprimento pré-ventral & 39,7 & 9 & 36,0 & 42,0 & 39,2 \\
\hline Comprimento pré-anal & 54,2 & 8 & 52,9 & 55,6 & 54,2 \\
\hline Comprimento ped. caudal & 8,6 & 8 & 8,5 & 9,9 & 9,0 \\
\hline Altura ped. caudal & 9,2 & 8 & 7,6 & 9,3 & 8,5 \\
\hline Comprimento nad. peitoral & 22,2 & 8 & 21,6 & 23,6 & 22,6 \\
\hline Comprimento nad. pélvica & 17,4 & 8 & 16,7 & 19,5 & 17,8 \\
\hline Distância peitoral-pélvica & 14,0 & 8 & 10,7 & 14,1 & 12,6 \\
\hline Distância pélvica-anal & 12,6 & 8 & 11,1 & 13,1 & 12,4 \\
\hline Dist. occipital-dorsal & 28,4 & 8 & 24,4 & 28,4 & 26,1 \\
\hline Distância dorsal-adiposa & 27,9 & 8 & 26,3 & 28,3 & 27,5 \\
\hline Comprimento cabeça & 24,8 & 8 & 24,2 & 27,0 & 25,3 \\
\hline Comprimento focinho & 6,1 & 8 & 5,5 & 7,0 & 6,4 \\
\hline Comprimento maxilar & 6,5 & 8 & 6,1 & 7,6 & 6,7 \\
\hline Espaço interorbital & 6,3 & 8 & 6,3 & 7,0 & 6,7 \\
\hline Diâmetro órbita & 9,9 & 8 & 9,9 & 11,5 & 10,7 \\
\hline \multicolumn{6}{|c|}{ Porcentagens do comprimento da cabeça } \\
\hline Comprimento focinho & 24,5 & 8 & 22,3 & 27,6 & 25,2 \\
\hline Diâmetro órbita & 39,8 & 8 & 39,8 & 44,4 & 42,2 \\
\hline Comprimento maxilar & 26,2 & 8 & 24,7 & 28,2 & 26,3 \\
\hline Espaço interorbital & 25,4 & 8 & 25,3 & 28,7 & 26,4 \\
\hline
\end{tabular}

na região mais basal, os cromatóforos são menores e concentram-se somente ao longo da margem posterior do primeiro segmento dos raios. Primeiro raio não-ramificado, geralmente mais pigmentado que os demais. Nadadeiras peitorais claras, com pigmentos marrons ao longo da margem interna dos raios; nadadeiras pélvicas claras, com pigmentos marrons dispostos ao longo das margens interna e externa dos raios. Nadadeira anal com a base e extremidade dos raios mais pigmentados, de modo a formar uma faixa clara na região mediana da nadadeira ou com a base pigmentada e a extremidade dos raios sem pigmentos. Alguns exemplares com os seis primeiros raios pigmentados. No holótipo, a faixa clara mediana possui alguns cromatóforos. Nadadeira caudal clara ou com pigmentos restritos ao lobo inferior (parátipos do $\mathrm{MNHN}$ ) ou com pigmentos em toda a margem da nadadeira (parátipo do USNM), sempre com uma faixa escura entre os raios medianos.
Coloração em vida. Conforme Planquette et al. (1996: 216), o corpo é translúcido, de modo que o esqueleto axial e os miômeros podem ser visualizados. O terço superior do globo ocular é vermelho; a base dos primeiros raios das nadadeiras dorsal e anal é vermelha com extremidade branca. Base dos lobos superior e inferior da nadadeira caudal, acima e abaixo da mancha caudal, vermelha, as vezes sobreposta por uma mancha branca. Mancha do pedúnculo losangular, estendendo-se entre os raios medianos da nadadeira caudal (Fig. 15).

Dimorfismo sexual. Foram examinados dois machos com 32,2 e 35,9 mm de CP. Apresentam ganchos nas nadadeiras anal e pélvicas. Nadadeira anal com ganchos retrorsos no primeiro raio não-ramificado e desde o primeiro até o sexto raio ramificado, dispostos na margem posterior do segundo ramo, geralmente um, raramente dois ganchos por segmento. No menor espécime há somente dois nódulos no segundo raio ramificado e pe- 
quenos ganchos no terceiro. Nadadeiras pélvicas com ganchos retrorsos desde o primeiro ou segundo até o quinto ou sexto raio ramificado, dispostos medialmente no segundo ramo e estendendo-se em direção à base, um gancho em cada segmento. Não foram encontrados ganchos nas nadadeiras peitorais.

Material examinado. Holótipo. Guiana Francesa:. Sistema do Rio Oiapoque, XII/1986, P.Y. Le Bail, P. Planquette et al. leg., MNHN 1999-1457 (47,6 mm CP). Parátipos. Guiana Francesa: Sistema do Rio Oiapoque, XII/1986, P.Y. Le Bail, P. Planquette et al. leg., coletados com o holótipo, MCP 34775 (34,2 mm CP), MNHN 2003-1457 (6, 28,9-38,5 mm CP); Petit Francois (Camopi), Rio Oiapoque, 16/jun/1972, E. Remole leg., USNM 310892 (2, 14,3-28,6 mm CP). Camopi (riacho ao lado de Roche-Mon Père, aproximadamente 15 minutos de canoa à jusante do Crique Sikini, sistema do Rio Oiapoque), 6/XI/2006, P.Y. Le Bail, S. FischMüller et. al. leg, MHNG 2682.003 (3, 28,8-30,0 mm CP).

Distribuição. Sistema do Rio Oiapoque, Guiana Francesa (Fig. 3).

Etimologia. Em homenagem aos Wayampi, grupo indígena que vive no alto Rio Oiapoque.

Comentários. Phenacogaster wayampi foi descrita e figurada em Planquette et al. (1996: 216-217) sob o nome Phenacogaster aff. megalostictus, em parte. Conforme os autores, a espécie distribui-se em quase todos os rios da Guiana Francesa, exceto nos rios Kourou e Orapu, onde não foi constatada a presença do gênero, e no Rio Iracoubo (veja mapa de distribuição na página 217). Ao examinarmos material proveniente da área de distribuição indicada por Planquette et al. constatou-se a presença de duas espécies: $P$. wayampi, encontrada unicamente no sistema do Rio Oiapoque, e $P$. wayana (rios Maroni, Mana, Sinnamary e Approuague). Phenacogaster aff. megalostictus (em parte $=P$. wayampi) foi considerada pelos autores mencionados acima muito semelhante à P. megalostictus do sistema do Rio Essequibo (Guiana), diferindo desta somente pela presença de intervalo na primeira fileira de dentes do pré-maxilar. Ao analisar material de $P$. wayampi verificou-se que a fileira externa de dentes do prémaxilar é variável, podendo ser completa ou apresentar um espaço correspondente a um ou mais dentes. Entretanto, a análise mostrou que outros caracteres podem ser úteis para separar a espécie de $P$. megalostictus: mancha umeral imediatamente acima ou contatando levemente a linha lateral (estendendo-se sobre a linha lateral em $P$. megalostictus), menor comprimento do maxilar em espécimes acima de $30 \mathrm{~mm}$ de CP $(24,7-27,5 \%$ vs 26,1a 31,5\% no CC em P. megalostictus, Fig. 16), maior número de dentes no maxilar (27-37 vs 9-21), maior número de escamas na linha lateral (37 a 38 vs 33-37), menor diâmetro orbital (9,9$11,5 \%$ vs 10,5-14,4\% no CP, Fig. 17), menor distância entre a base do último raio das nadadeiras peitorais e a origem das nadadeiras pélvicas em espécimes acima de $30 \mathrm{~mm}$ de CP (12,0$14,1 \%$ vs 7,3-13,0\% no CP, Fig. 18), e ausência de ganchos nas nadadeiras peitorais ( $v s$ presença). Conforme Planquette et al. (1996: 216), P. wayampi habita riachos de curso rápido com fundo de areia e pedra, mantendo-se em posição contra-corrente.
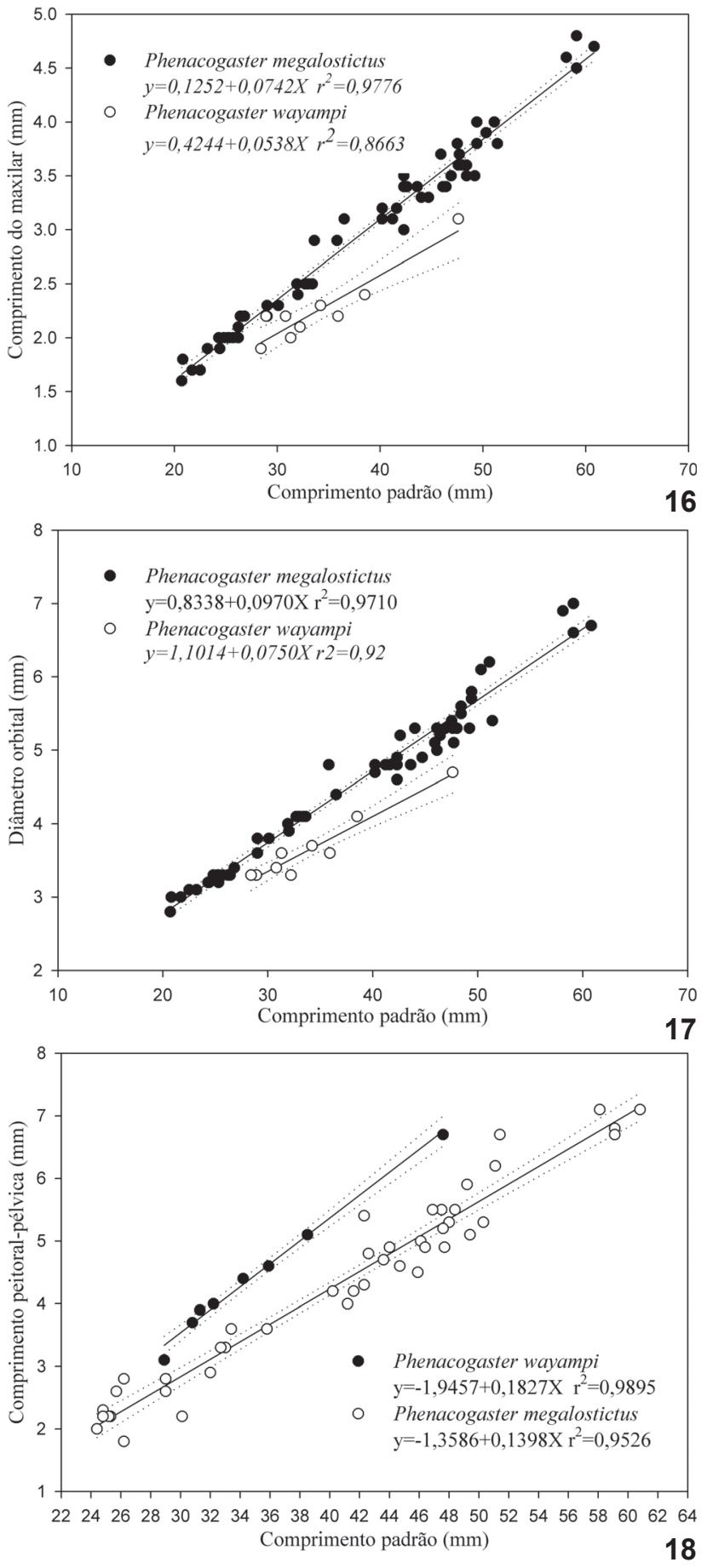

Figuras 16-18. (16) Regressão linear do comprimento do maxilar sobre o comprimento padrão em $P$. megalostictus e $P$. wayampi; (17) regressão linear do diâmetro orbital sobre o comprimento padrão em $P$. megalostictus e $P$. wayampi; (18) regressão linear do comprimento peitoral-pélvica sobre o comprimento padrão em $P$. megalostictus e $P$. wayampi. Linhas tracejadas indicam o intervalo de confiança de $95 \%$. 


\section{Phenacogaster wayana sp. nov. Le Bail \& Lucena Figs 19-21}

Phenacogaster aff. megalostictus - Géry \& Planquette, 1982: 72 (descrição e figura 20). - Géry et al., 1991: 42 (somente exemplares do sistema do Approuague).

Diagnose. Phenacogaster wayana difere das espécies do complexo $P$. pectinatus pela presença de conspícua mancha umeral, maior que a metade do diâmetro orbital, em machos e fêmeas, (vs mancha umeral ausente ou restrita a poucos cromatóforos em machos e estreita, usualmente menor que a metade do diâmetro orbital nas fêmeas) conspícua mancha no pedúnculo caudal ( $v s$ ausente ou restrita a poucos cromatóforos), 28-35 raios ramificados na nadadeira anal (média entre 31,2-33,4 - veja Fig. 22 para média nas diferentes populações) vs 33-42 (média entre 35 e 39 - variável nas diferentes populações). Diferencia-se das demais espécies do gênero por apresentar mancha umeral arredondada ou ovalada ( $v s$ verticalmente alongada em $P$. maculoblongus, $P$. ojitatus, $P$. prolatus), mancha umeral presente em machos e fêmeas ( $v s$ ausente em P. carteri e em machos de $P$. capitulatus e P. napoatilis); mancha umeral situada acima das escamas da linha lateral ( $v s$ estendendo-se sobre as escamas da linha lateral em $P$. megalostictus e $P$. prolatus); mancha umeral mais próxima do pseudotímpano do que da vertical que passa pela origem da nadadeira dorsal ( $v s$ mancha umeral situada na vertical que passa abaixo ou imediatamente à frente da nadadeira dorsal em $P$. tegatus); mancha no pedúnculo caudal conspícua (vs ausente em $P$. carteri e $P$. prolatus); mancha do pedúnculo caudal não alongada, sua região anterior não alcança a extremidade posterior da nadadeira adiposa ( $v s$ mancha alongada, alcançando a extremidade posterior da nadadeira adiposa em $\mathrm{P}$. wayampi); linha lateral completa (vs incompleta com em $P$. capitulatus, $P$. carteri, P. napoatilis, $P$. tegatus); linha lateral com 37-39 (média 37,9) escamas perfuradas (vs 35-37 em $P$. calverti (média 35,7), 34-37 (média 35,7) em $P$. franciscoensis e 33-37 (média 35) em P. megalostictus); dois a três, geralmente dois, dentes na região medial da fileira externa do pré-maxilar ( $v s$ um a dois, geralmente um em P. calverti;); maxilar com 20-37 dentes cônicos (vs 9-20, raramente 21 em $P$. megalostictus); 28-35 raios ramificados na nadadeira anal (média 31,9, veja Fig. 22 para média nas diferentes populações) (vs 32-42 nas espécies do complexo $P$. pectinatus, veja Fig. 23 para média nas diferentes populações; 33-38, média 35,4 em $P$. prolatus); ganchos ausentes nas nadadeiras peitorais dos machos (vs presentes em P.capitulatus, P. carteri, P. napoatilis, P. maculoblongus, P. megalostictus, $P$. retropinnus $P$. simulatus); ganchos presentes nas nadadeiras pélvicas dos machos ( $v$ s ausentes em $P$. carteri, $P$. jancupa, $P$. napoatilis); altura do corpo de 30,2-38,5\% do CP em espécimes acima de $30 \mathrm{~mm}$ de CP (vs 27,3-31,7\%, em P. simulatus e 26,5$31,8 \%$ em $P$. retropinnus); comprimento pré-anal 49,7-55,9\% do CP (vs 53-59,9 em P. calverti e 54,4-60,6\% em P. ojitatus); terceiro infra-orbital relativamente grande, sua margem inferior deixa um espaço relativamente pequeno entre a margem horizontal do pré-opérculo ( $v s$ pequeno, com espaço relativamente grande
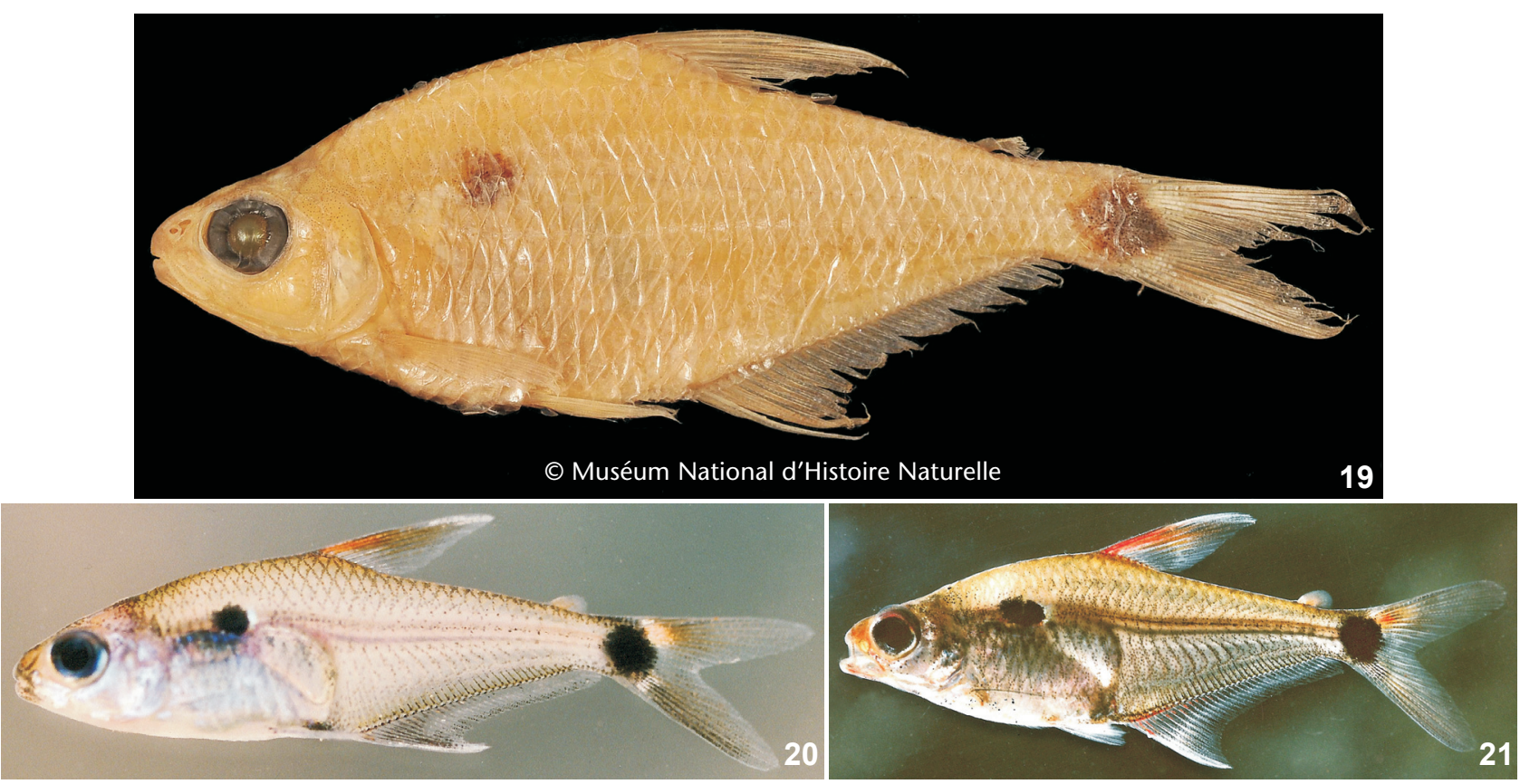

Figuras 19-21. Phenacogaster wayana sp. nov.: (19) MNHN 2003-2565, holótipo, 41,3 mm CP, Crique Japigny, Guiana Francesa; (20) exemplar vivo do Rio Mana, Guiana Francesa. Foto P.Y Le Bail; (21) exemplar vivo do Rio Maroni, Guiana Francesa. Foto P. Planquette. 


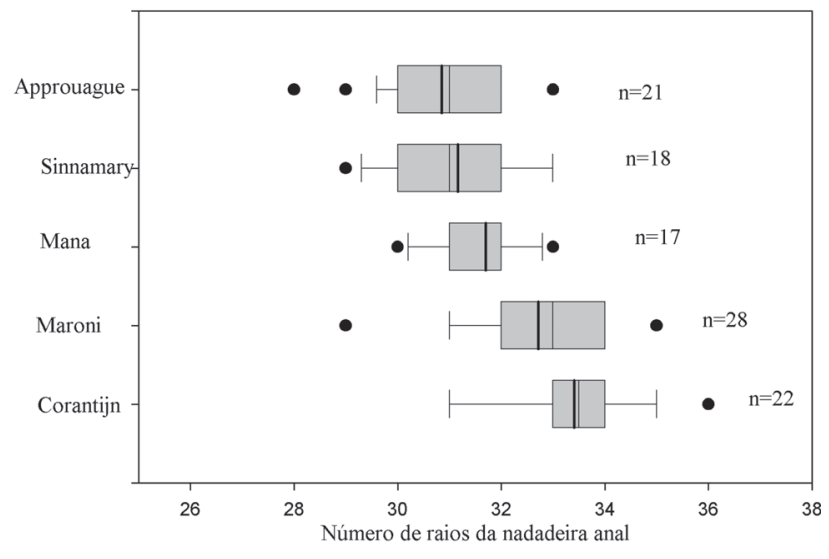

Figura 22. Distribuição do número de raios ramificados da nadadeira anal nas populações de $P$. wayana. Há uma diferença estatística significativa entre as contagens das populações dos rios Corantijn e Approuague ( $T=6,701 ; p=<0,001)$, dos rios Corantijn e Sinnamary ( $T=5,444 ; p=<0,001)$. As contagens entre as populacões dos rios Maroni e Approuague $(T=317,000 ; p=$ $<0.001)$ e dos rios Maroni e Sinnamary $(T=3,609 ; p=<0.001)$ também são significativamente diferentes quando aplicado o teste Mann-Whitney rank-sum. Nenhuma diferença estatística foi encontrada entre as populações dos rios Corantijn e Maroni. Linha vertical preta interna ao retângulo corresponde à média. Linha vertical fina interna ao retângulo corresponde à mediana.

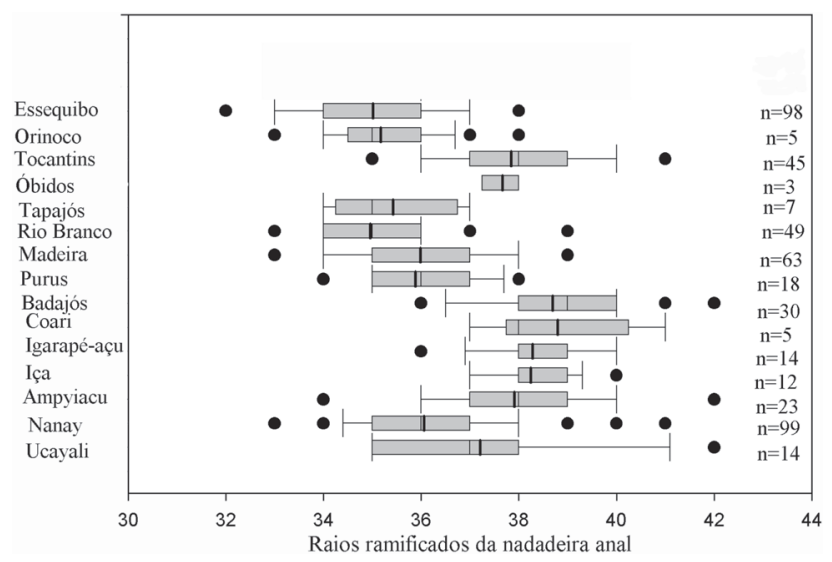

Figura 23. Variação do número de raios ramificados da nadadeira anal no complexo Phenacogaster pectinatus.

entre a sua margem inferior e a margem horizontal do préopérculo em $P$. jancupa).

Descrição. Dados morfométricos na tabela IX. Corpo comprimido, perfil dorsal convexo do focinho até a origem da nadadeira dorsal ou levemente convexo desde o focinho até o final da região interorbital, continuando reto ou côncavo até a base do processo supra-occipital; elevando-se e tornando-se convexo da base do processo supra-occipital até a origem da nadadeira dorsal; declinando-se e tornando-se reto desde a origem da nadadeira dorsal até o fim do pedúnculo caudal; raramente levemente convexo ao longo da base da nadadeira dorsal. Perfil ventral do corpo convexo da extremidade da mandíbula até a origem da nadadeira anal, algumas vezes quase retilíneo entre as nadadeiras peitorais e a origem da nadadeira anal em espécimes abaixo de $30 \mathrm{~mm}$ de CP; elevando-se e tornando-se reto, raramente com leve convexidade, ao longo da base da nadadeira anal e reto no pedúnculo caudal. Extremidade da maxila superior situa-se no mesmo nível ou ultrapassa levemente a ponta da mandíbula. Boca situada abaixo da linha mediana horizontal da órbita. Terceiro infra-orbital relativamente grande, sua margem inferior separada da margem horizontal do pré-opérculo por um espaço de $1 / 6$ a $1 / 8$ do seu comprimento, raramente $1 / 5$ e até $1 /$ 11 nos espécimes do sistema do Rio Corantijn; margem posterior separada da margem vertical do pré-opérculo por um espaço aproximadamente igual ou menor, alcançando a margem do préopérculo nos espécimes provenientes do Rio Corantijn. Duas fileiras de dentes no pré-maxilar, fileira externa interrompida, raramente completa nas populações dos sistemas dos rios Approuague, Maroni e Sinnamary, com 3-11 dentes totais (sete no holótipo, três em três parátipos do sistema do Rio Corantijn e 11 em um parátipo do Rio Sinnamary, média $=6,1 ; \mathrm{n}=82$ ). Quando interrompida, possui 3-9 dentes totais, sendo dois, raramente três tricúspides (um em um espécime do Rio Sinnamary e no pré-maxilar direito de um espécime do Rio Corantijn) na região medial, mais largos e maiores que os da região lateral, e 16 tricúspides e cônicos ou somente cônicos, delgados e menores, na região lateral (um em três espécimes do Rio Corantijn e seis em três espécimes do Rio Maroni). Quando completa possui 7-11 dentes tricúspides e cônicos (11 em um espécime do Rio Sinnamary), que decrescem em comprimento e largura, tornando-se posteriormente bem mais delgados e menores. Fileira interna com 6-11 dentes (nove no holótipo, seis em um espécime do Rio Approuague e 11 em um espécime do Rio Maroni, média $=8,3 ; \mathrm{n}=78$ ), todos ou quase todos tricúspides que decrescem em tamanho e largura, de modo que, aproximadamente, os três últimos são mais delgados, tricúspides e/ou cônicos. Alguns espécimes possuem um dente cônico localizado na porção posterior do pré-maxilar, entre as fileiras interna e externa (um espécime com dois). Maxilar com 22-37 dentes cônicos (aproximadamente 34 no holótipo, 20 em dois espécimes do Rio Mana média $=24,6 ; \mathrm{n}=62$ ) situados ao longo de quase toda a margem ventral do osso. Dentário com 13-17 dentes em uma única fileira, 4-7 tricúspides (quatro presentes somente na população dos rios Maroni e Mana) maiores que os demais seguidos de 8-12 cônicos ou com pequeníssimas cúspides e mais delgados. Nadadeira dorsal com ii, 9 raios. Origem da nadadeira anal localizada próxima à metade do corpo. Nadadeira anal com iii-v,28-36 raios (iii,28 no holótipo, v em dois espécimes; veja variação geográfica em Comentários). Origem da nadadeira anal localizada na vertical que passa próxima à base do quarto ao quinto raio 


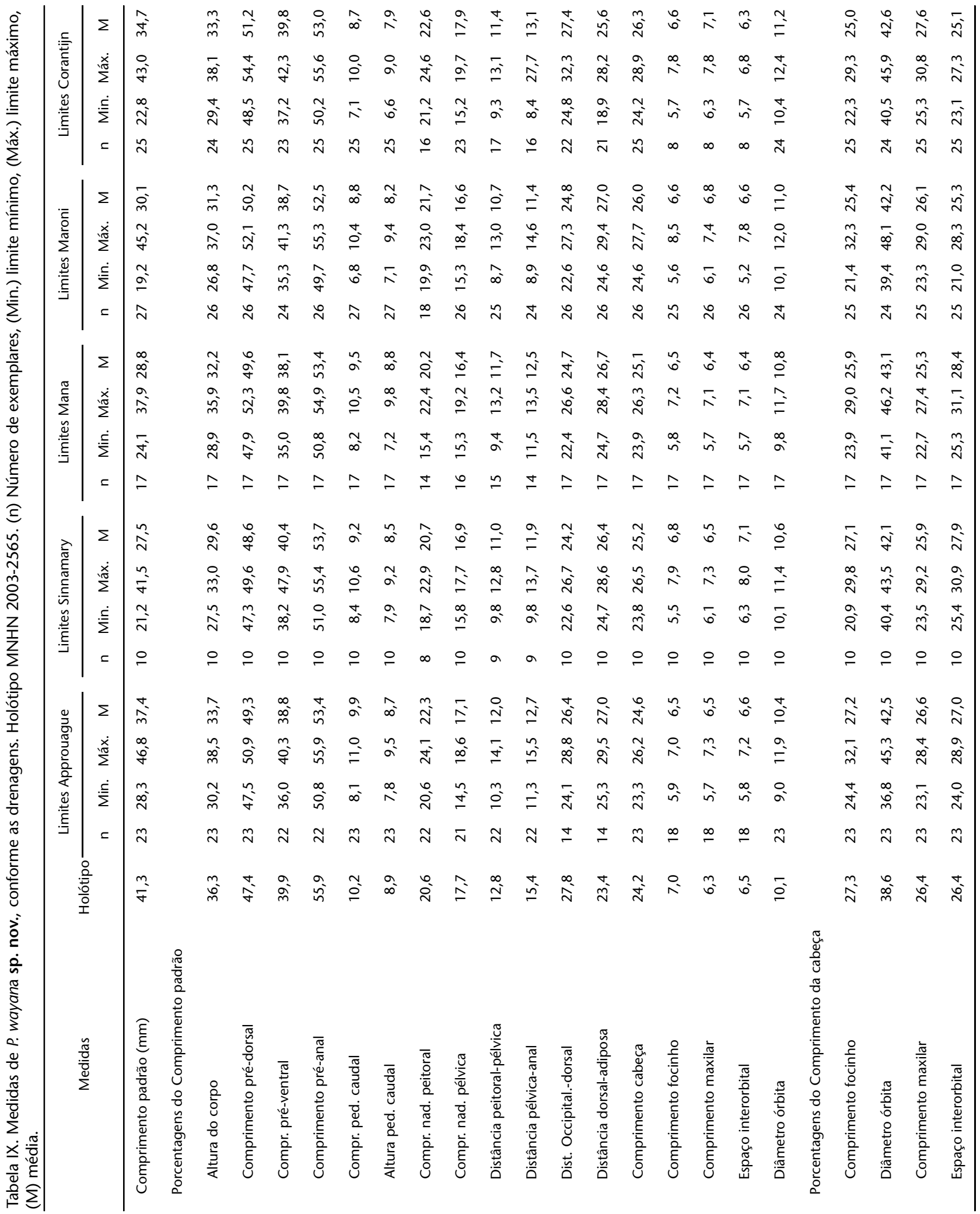


ramificado da nadadeira dorsal ou pela base do segundo ou terceiro raio ramificado em espécimes não-tipo. Margem anterior da nadadeira anal côncava, o último raio não-ramificado e os cinco a seis primeiros ramificados maiores que os demais (os três primeiros aproximadamente do mesmo tamanho); uma bainha de aproximadamente sete a oito escamas ao longo da base da nadadeira, que se estende até o sétimo ou oitavo raio ramificado. Nadadeiras peitorais com i,10-15 raios (12 no holótipo, 10 em um espécime do Rio Corantijn e 15 em outro; média = 12,3; $\mathrm{n}=100$ ); extremidade posterior do raio mais longo ultrapassa a origem das nadadeiras pélvicas, não atingindo a metade dessas nadadeiras; nadadeiras peitorais totalmente desenvolvidas em indivíduos a partir de 21,5 mm de CP e, em geral, não-desenvolvidas abaixo desse comprimento. Margem posterior do cleitro com ou sem reentrância ou levemente ondulado. Nadadeiras pélvicas com 1,7 raios (sem nadadeiras em um espécime do Rio Approuague), ultrapassam levemente a origem da nadadeira anal (atinge em um espécime do Rio Approuague), alcançando, no máximo, o segundo raio ramificado da nadadeira anal (o terceiro em alguns espécimes do Rio Corantijn e em alguns com aproximadamente $22 \mathrm{~mm}$ de CP do Rio Maroni). Linha lateral com 37-39 escamas perfuradas (38 no holótipo, média $=37,9 ; \mathrm{n}=$ 58). Cinco a seis fileiras de escamas entre a origem da nadadeira dorsal e a linha lateral (seis no holótipo) e 4-6 entre a linha lateral e a origem da nadadeira anal (quatro e seis somente em espécimes dos rios Sinnamary e Maroni, respectivamente). Presença de uma única escama sobreposta entre 1-5 pares (seis em um espécime do Rio Mana) de escamas pré-ventrais, localizadas entre as origens das nadadeiras peitorais e pélvicas. Ramo superior do primeiro arco branquial com 3-5 rastros (quatro no holótipo, três somente em sete espécimes do Rio Maroni e Mana, média = 4,$3 ; \mathrm{n}=95$ ) e ramo inferior com 7-10 rastros (oito no holótipo, 10 somente em um espécime do Rio Corantijn, média $=8,2 ; \mathrm{n}=$ 101). Vértebras totais 34-36, pré-caudais $14-15$ e caudais $20-21$. Quatro a cinco supraneurais.

Coloração em álcool. A coloração geral do corpo é levemente ou fortemente amarela. Região laterodorsal com cromatóforos castanhos, dispostos na borda das escamas, próximos ao dorso e espalhados uniformemente mais abaixo. Região lateroventral, entre a origem das nadadeiras peitorais até próximo à origem da nadadeira anal menos pigmentada ou com pigmentos restritos à borda das escamas. Região entre a linha lateral e a nadadeira anal os cromatóforos estão dispostos uniformemente, porém destacam-se cromatóforos que se dispõem em forma de $>$, demarcando os mioseptos. Imediatamente acima da base da nadadeira anal, os cromatóforos situam-se transversalmente em relação ao eixo do corpo, entre cada raio da nadadeira. Opérculo com cromatóforos concentrados na região superior ou estendendo-se na região mediana. Região dorsal da cabeça e dorso do corpo mais intensamente pigmentados ou tão pigmentados quanto a região laterodorsal do corpo. Mancha umeral relativamente grande, conspícua, arredondada ou ovalada (um único espécime com mancha verticalmente ovalada, provavelmente pela despigmentação da parte anterior), situada imediatamente acima da quinta à oitava escamas da linha lateral (um espécimetipo com a mancha levemente sobre a região superior da escama da linha lateral; situa-se, geralmente, desde a primeira ou imediatamente à frente da segunda costela até a quinta ou entre a quarta e quinta costela. Seu comprimento horizontal é maior que a metade do diâmetro orbital. Uma linha escura, na região médio-lateral do corpo, estende-se desde a região imediatamente posterior da mancha umeral - algumas vezes mais conspícua uma escama após o pseudotímpano ou a partir da origem da nadadeira dorsal - até o início da mancha do pedúnculo caudal; geralmente essa linha torna-se mais fraca a partir da vertical que passa pela origem da nadadeira adiposa. Imediatamente abaixo e ao longo dessa linha estende-se uma faixa quase desprovida de pigmentação. Pedúnculo caudal com uma larga e conspícua mancha que se prolonga fortemente entre os raios da nadadeira caudal, constituindo uma forma losangular. Em espécimes nãotipos, a mancha do pedúnculo é, normalmente, mais estreita que a dos tipos, deixando uma área mais despigmentada na região dorsal e, principalmente, na região ventral do pedúnculo. Nadadeira dorsal com pigmentos ao longo das margens anterior e posterior dos raios e das membranas inter-radiais (ou em toda a extensão das membranas), as quais são normalmente despigmentadas no terço inferior e despigmentadas a partir do quarto ou quinto raio ramificado. Primeiro raio não-ramificado da nadadeira raramente mais pigmentado que os demais. Nadadeiras peitorais e pélvicas claras com pigmentos uniformemente dispostos ao longo das margens anterior e posterior dos raios ou somente ao longo da margem posterior; porção distal, algumas vezes, quase desprovida de pigmentação. Nadadeira anal totalmente pigmentada - com pigmentos mais concentrados na região ao longo da porção mais basal e da extremidade dos raios, e mais esparsos na porção mediana - ou com pigmentos somente ao longo da porção mais basal. Nadadeira caudal com ou sem uma região clara ao redor da mancha caudal, bem visível e sempre presente na população do Rio Mana.

Coloração em vida. Baseada em fotografias de Paul Planquette. Apresentam o corpo translúcido. A parte mais basal dos primeiros raios da nadadeira dorsal é vermelha e a mais distal, branca. Os primeiros raios da nadadeira anal são brancos, com uma pequena parte basal vermelha. Extremidade dos raios da nadadeira anal escura, região mediana clara. A mancha do pedúnculo caudal é arredondada e estende-se um pouco além da base da nadadeira caudal. Uma mancha avermelhada na base do lobo superior da nadadeira; com ou sem mancha branca na base da nadadeira, ao redor da mancha caudal (Figs 20 e 21).

Dimorfismo sexual. Foram examinados 22 machos, medindo de 28,1 a 42,0 mm CP. Apresentam ganchos sobre as nadadeiras anal e pélvicas. Nadadeira anal com ganchos levemente retrorsos que podem estar situados desde o último raio nãoramificado até o nono ramificado (décimo em não-tipos), dispostos latero-posteriormente no segundo ramo; usualmente um, raramente dois ganchos por segmento. Nadadeiras pélvicas com 
ganchos retrorsos que podem estar situados desde o primeiro raio não-ramificado até o penúltimo raio ramificado, dispostos, medialmente, ao longo de quase toda a extensão do raio, menos numerosos no primeiro ramo. Geralmente, um gancho por segmento. Primeiro ramo do primeiro raio ramificado sem ganchos.

Material examinado. Holótipo. Guiana Francesa: Crique Japigny (sistema do Rio Approuague), 23/XI/1988, T. Boujard, F. Meunier \& M. Pascal leg., MNHN 2003-2565 (41,3 mm CP). Parátipos. Guiana Francesa: Rio Approuague (Kaw, entre Saut Grand Mathias e Saut Grand Kanori), IV/1983, P. Y. Le Bail leg., MHNG 2227.022 (5, 35,4-45,6 mm CP); Crique Japigny (sistema do Rio Approuague), 23/XI/1988, T. Boujard, F. Meunier \& M. Pascal leg., coletados juntamente com o holótipo, MNHN 2003-2566 (3, 42,9-43,4 mm CP), MCP 34721 (1, 38,1 mm CP); sistema do Rio Approuague, 1/IV/1983, P. Y. Le Bail leg., MNHN 2003-2567 (7, 28,3-38,6 mm CP), MCP 34722 (3, 33,8-35,9 mm CP, 2 d\&c, 34,3 mm CP); sistema do Rio Approuague, IX/1986, P. Planquette leg., MNHN 2003-2568 (2, 44,7-46,8 mm CP). Sistema do Rio Sinnamary (acima de Saut Mouches), 2/VIII/1994, MHNG 2616.094 (3, 25,5-41,5 mm CP); afluente da margem esquerda do Rio Sinnamary ( acima de Saut Takari Tanté), 12/ VI/1996, MHNG 2616.093 (6, 21,2-28,3 mm CP); Crique Balate ( sistema do Rio Maroni, 05² 28'59"N 54² 2'59”'W, coordenadas aproximadas), 4/III/1980, MNHN 2003-2569 (8, 32,0-38,4 mm CP), MCP 34723 (2, 32,0-33,8 mm CP, 1 d\&c 32, 0 mm CP); Rivière Grand Inini (sistema do Rio Maroni, $03^{\circ} 40^{\prime} 00^{\prime \prime} \mathrm{N}$ $53^{\circ} 49^{\prime} 59^{\prime \prime} \mathrm{W}$, coordenadas aproximadas), 27/IX/1997, MNHN 2003-2570 (9, 17,7-24,7 mm CP), MCP 34724 (3, 23,6-24,7 mm $\mathrm{CP}$ ); Rivière Grand Inini (sistema do Rio Maroni, Bief,

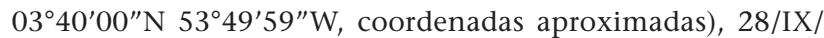
1997, MNHN 2003-2571 (3, 21,3-32,6 mm CP); Rivière Tampock (sistema do Rio Maroni, $03^{\circ} 27^{\prime} 00^{\prime \prime N} 54^{\circ} 00^{\prime} 00^{\prime \prime} \mathrm{W}$, coordenadas aproximadas), 17/XI/1998, MNHN 2003-2572 (3, 37,0-45,2 mm $\mathrm{CP}$ ); Crique Lezard (sistema do Rio Mana, Citron, 0456'59"N $53^{\circ} 47^{\prime} 59^{\prime \prime} \mathrm{W}$, coordenadas aproximadas), 4/X/1995, MNHN 2003-2573 (13, 24,1-37,9 mm CP), MCP 34725 (4,27,6-34,1 mm CP; 1 d\&c 30,6 mm CP); afluente do Rivière Ouaqui (sistema do Rio Maroni, $03^{\circ} 25^{\prime} 00^{\prime \prime} \mathrm{N} 53^{\circ} 49^{\prime} 59^{\prime \prime} \mathrm{W}$, coordenadas aproximadas), 9/V/1971, USNM 310895 (19,3 mm CP). Suriname, Nickerie: afluente do Rio Corantijn (ao norte de Tiger Falls, $\left.04^{\circ} 00^{\prime} \mathrm{N}, 58^{\circ} 02^{\prime} \mathrm{W}\right), 16 / \mathrm{IX} / 1980, \mathrm{MCP} 44010$ (4, 36,4-42,0; 2 d\&c 36,4-38 mm CP), USNM 225185 (14, 24,8-43,0 mm CP); afluente na margem sul do Rio Lucie (sistema do Rio Corantijn

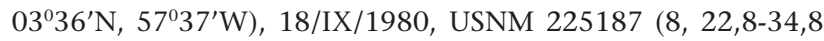
mm CP). Não-tipos. Guiana Francesa: Foram examinados RX do seguinte material sistema do Rio Maroni, Antecume Pata, 12/ out/1998, MNHN 1998-1828 (5, não medidos, examinados somente RX); Rivière Tampock, sistema do Rio Maroni, Saut Pierkuru, MNHN 2000-6398 (11, não medidos, examinados somente RX); Rio Sinnamary, Petit Saut, 2/fev/1983, MNHN 2001-1593 (6, não medidos, examinados somente RX); Rio Sinnamary, Petit Saut, 14/fev/1985, MNHN 2001-1594 (8, não medidos, examinados somente RX).
Distribuição. Sistema do Rio Corantijn (Suriname) e sistemas dos rios Maroni, Mana, Sinnamary e Approuague, Guiana Francesa (Fig. 3).

Etimologia. Em homenagem aos Wayana, grupo indígena que vive no alto Rio Maroni.

Comentários. Os comentários a seguir estão limitados à baixa representatividade das amostras nos diferentes sistemas hidrográficos; algumas amostras não abrangem todos os tamanhos e não possuem espécimes de ambos os sexos. Por exemplo, a maioria das amostras examinadas da população do Rio Approuague constitui-se de espécimes com comprimento acima de $30 \mathrm{~mm}$ de $\mathrm{CP}$, sendo que somente dois espécimes apresentam tamanho inferior. Nas amostras da população do Rio Sinnamary, a maioria é representada por espécimes com comprimento abaixo de $30 \mathrm{~mm}$ de $\mathrm{CP}$, e somente dois medem acima de $30 \mathrm{~mm}$ de CP. Igualmente, não foram identificados espécimes machos na população dos rios Sinnamary e Mana. Nas amostras dos demais sistemas, os poucos machos são de tamanhos não-comparáveis. Não foram encontradas diferenças significativas nas proporções corporais que permitissem distinção taxonômica entre as populações de $P$. wayana. No entanto, embora haja sobreposição no número de raios ramificados da nadadeira anal, as populações que habitam os rios do limite oeste de distribuição - Corantijn e Maroni - possuem a média do número de raios da nadadeira anal significativamente diferente da média encontrada nas populações que habitam os rios do extremo leste de distribuição da espécie - Approuague e Sinnamary. Verifica-se um aumento do número de raios de oeste para leste (Fig. 22). A média do número de raios da população que habita o Rio Mana, região intermediária, não mostrou diferença significativa quando comparada com as médias das demais populações. Do mesmo modo, a população do Rio Corantijn apresentou diâmetro orbital e comprimento da cabeça relativamente maiores em relação à população do sistema do Rio Approuague. Entretanto, os valores dessas medidas se sobrepuseram ao incluir-se, na análise, os dados das demais populações dos sistemas intermediários. A média do número de rastros branquiais do ramo inferior do primeiro arco branquial mostrou ser significativamente diferente quando comparadas as duas populações que habitam os rios com limite mais a oeste - Corantijn - e a leste - Approuague (Fig. 24). Também houve variação na média do número de dentes do pré-maxilar entre as populações. A população do Rio Corantijn apresentou a média do número de dentes da primeira fileira do pré-maxilar menor e significativamente diferente das populações dos sistemas dos rios Maroni e Approuague, comparando-se somente espécimes com fileira de dentes interrompida. O exame do material mostrou que as nadadeiras peitorais já estão totalmente desenvolvidas em espécimes com 21,5 mm de CP ou mais. Abaixo desse comprimento, um único espécime de 17,7 mm de CP (Rio Maroni) apresentou as nadadeiras totalmente desenvolvidas. Nos demais, as nadadeiras não estão desenvolvidas: sem nenhum raio em indivíduos de 15,0 a 16,4 mm de CP (Rio 
Sinnamary) e somente alguns raios desenvolvidos em espécimes de 18,4 a $21,2 \mathrm{~mm}$ de CP (rios Maroni e Sinnamary). $P$. wayana foi incluída, juntamente com $P$. wayampi, sob o nome de $P$. aff. megalostictus em Planquette et al. (1996: 216). Conforme os autores, a espécie distribui-se em quase todos os rios da Guiana Francesa, exceto nos rios Kourou e Orapu, onde não foi constatada a presença do gênero, e no Rio Iracoubo (veja mapa de distribuição na página 217). Ao examinar material proveniente da área de distribuição indicada por Planquette et al. constatou-se a presença de duas espécies: $P$. wayampi, encontrada unicamente no sistema do Rio Oiapoque, e P. wayana (rios Maroni, Mana, Sinnamary e Approuague). Phenacogaster aff. megalostictus (em parte, = Phenacogaster wayana) foi considerada pelos autores mencionados acima muito semelhante à $P$. megalostictus do sistema do Rio Essequibo (Guiana), diferindo desta somente pela presença de intervalo na primeira fileira de dentes do pré-maxilar. Ao analisar material das populações dos diferentes sistemas hidrográficos de $P$. wayana verificou-se que a fileira externa de dentes do pré-maxilar, embora geralmente interrompida, pode ser semelhante à de $P$. megalostictus, completa. Entretanto, a análise mostrou que outros caracteres podem ser úteis para separar a espécie de $P$. megalostictus: mancha umeral acima das escamas da linha lateral (vs sobre as escamas da linha lateral), 20-37 dentes cônicos no maxilar, média $=24,6$ (vs 9-21 média $=16$ ), 37-39 escamas na linha lateral média $=$ 37,9 (vs 33-37 média = 35), espécimes abaixo de $30 \mathrm{~mm}$ de $\mathrm{CP}$ com menor comprimento da cabeça $(23,8-28,9 \%$ vs $28,1-31,7 \%$ do CP), menor diâmetro orbital (10,2-12,4\% vs $12,4-14,4 \%$ do $\mathrm{CP})$, menor comprimento do maxilar $(5,7-7,8$ vs 7,6-8,7\% do $\mathrm{CP}$ ) e ausência de ganchos sobre as nadadeiras peitorais de espécimes machos ( $v s$ presença). Espécimes não-tipo radiografados com 33-37 vértebras totais, geralmente 36: pré-caudais e 14 e caudais 19 (1), pré-caudais 15 e caudais 20 (4), pré-caudais 15 e caudais 21 (22), pré-caudais 15 e caudais 22 (1).

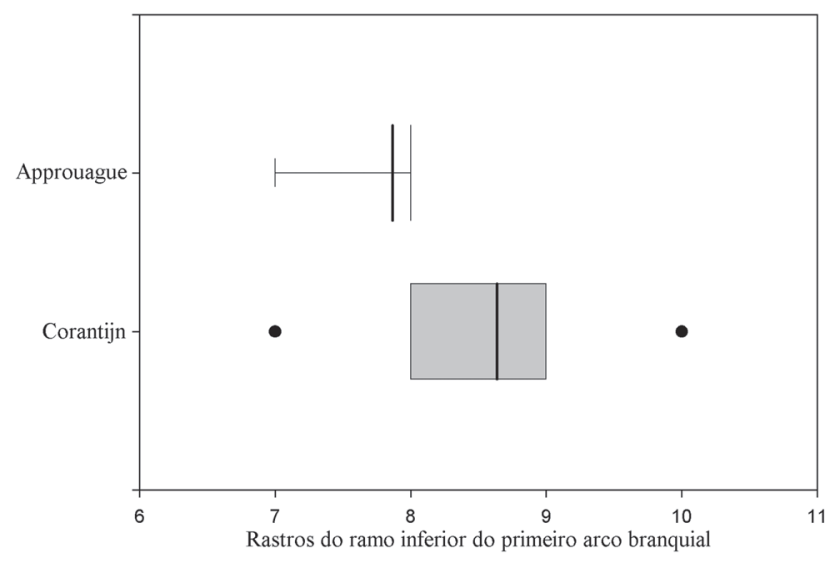

Figura 24. Variação do número de rastros do ramo inferior do primeiro arco branquial nas populações de $P$. wayana do Rio Corantijn e do Rio Approuague.
Características diferenciais e comentários sobre as espécies $P$. apletostigma, $P$. calverti, $P$. carteri, $P$. franciscoensis, $P$. jancupa, $P$. megalostictus e $P$. tegatus

\section{Phenacogaster apletostigma Lucena \& Gama, 2007}

Phenacogaster apletostigma Lucena \& Gama, 2007: 152, figs 1-2, localidade-tipo: Amapá, canal principal do Rio Santo Antônio, sistema do Rio Araguari.

Diagnose. Phenacogaster apletostigma difere de todas as demais espécies do gênero por apresentar uma grande mancha umeral, verticalmente alongada, que se estende desde a linha lateral até a penúltima fileira longitudinal de escamas da região laterodorsal e é provida de um prolongamento ântero-superior. Essa forma de mancha, única no gênero, é considerada uma autapomorfia da espécie.

Material examinado. Holótipo. BrasiL, Amapá: município de Porto Grande, canal principal do Rio Santo Antônio (sistema do Rio Araguari, 01 ${ }^{\circ} 06^{\prime} 04.38^{\prime \prime N}$, 51 53'36.74”W), 5-12/III/ 2005, Cecile Gama et al leg., IEPA 2488, 40,9 mm CP. Parátipos. Brasil, Amapá: município de Porto Grande, canal principal do Rio Santo Antônio (sistema do Rio Araguari, 01 $06^{\prime} 04.38^{\prime \prime} \mathrm{N}$ $\left.51^{\circ} 53^{\prime} 36.74^{\prime \prime} \mathrm{W}\right), 5-12 / \mathrm{III} / 2005$, Cecile Gama et al. leg., coletados juntamente com o holótipo, IEPA 2339 (4; 30,3-32,4 mm CP, 1 macho d\&c 32,4 mm CP), MCP 40087 (5; 28,3-36,1 mm CP); município de Pedra Branca do Amapari, Igarapé Amapá: (afluente do Rio Cupixi, sistema do Rio Amapari, 00 $35^{\prime} 04.53^{\prime \prime} \mathrm{N}$, $\left.52^{\circ} 20^{\prime} 8.38^{\prime \prime} \mathrm{W}\right), 28 / \mathrm{VII} / 2005$, Simone Costa et al. leg., IEPA 2340 (1; 24,9 mm CP); município de Pedra Branca do Amapari, Igarapé Amapá (afluente do Rio Cupixi, sistema do Rio Amapari, $\left.00^{\circ} 34^{\prime} 45.80^{\prime \prime} \mathrm{N} 52^{\circ} 19^{\prime} 8.30^{\prime \prime} \mathrm{W}\right), 29 / \mathrm{VII} / 2005$, Valdeci Leão leg., IEPA 2341 (1; 22,4 mm CP); município de Pedra Branca do Amapari,. Igarapé Amapá (afluente do Rio Cupixi, sistema do Rio Amapari, 00³4'40.19"N 52 19'21.73"W), 03/VIII/2005, Simone Costa et al. leg., IEPA 2342 (2; 22,3-25,0 mm CP).

\section{Phenacogaster calverti (Fowler, 1941)}

Figs 25-27

Grammabrycon calverti Fowler, 1941: 190, figs 99-100 (espécietipo de Grammabrycon Fowler, descrição original, localidade-tipo: Forteleza [Fortaleza], Ceará).

Phenacogaster calverti - Géry, 1972: 10 (nova combinação).

Diagnose. Phenacogaster calverti difere de todas as demais espécies de Phenacogaster por apresentar usualmente um dente na região medial da fileira externa do pré-maxilar, raramente dois ( $v s$ dois ou mais, raramente um nas demais espécies). Distingue-se também pelo seguinte conjunto de caracteres: focinho abrupto, mancha umeral conspícua, horizontalmente ovalada ou arredondada, presente em machos e fêmeas; mancha umeral não se estendendo sobre as escamas da linha lateral; mancha do pedúnculo com seu limite anterior não alcançando a vertical que passa pela extremidade posterior da nadadeira adiposa, infra-orbital relativamente grande, margem poste- 

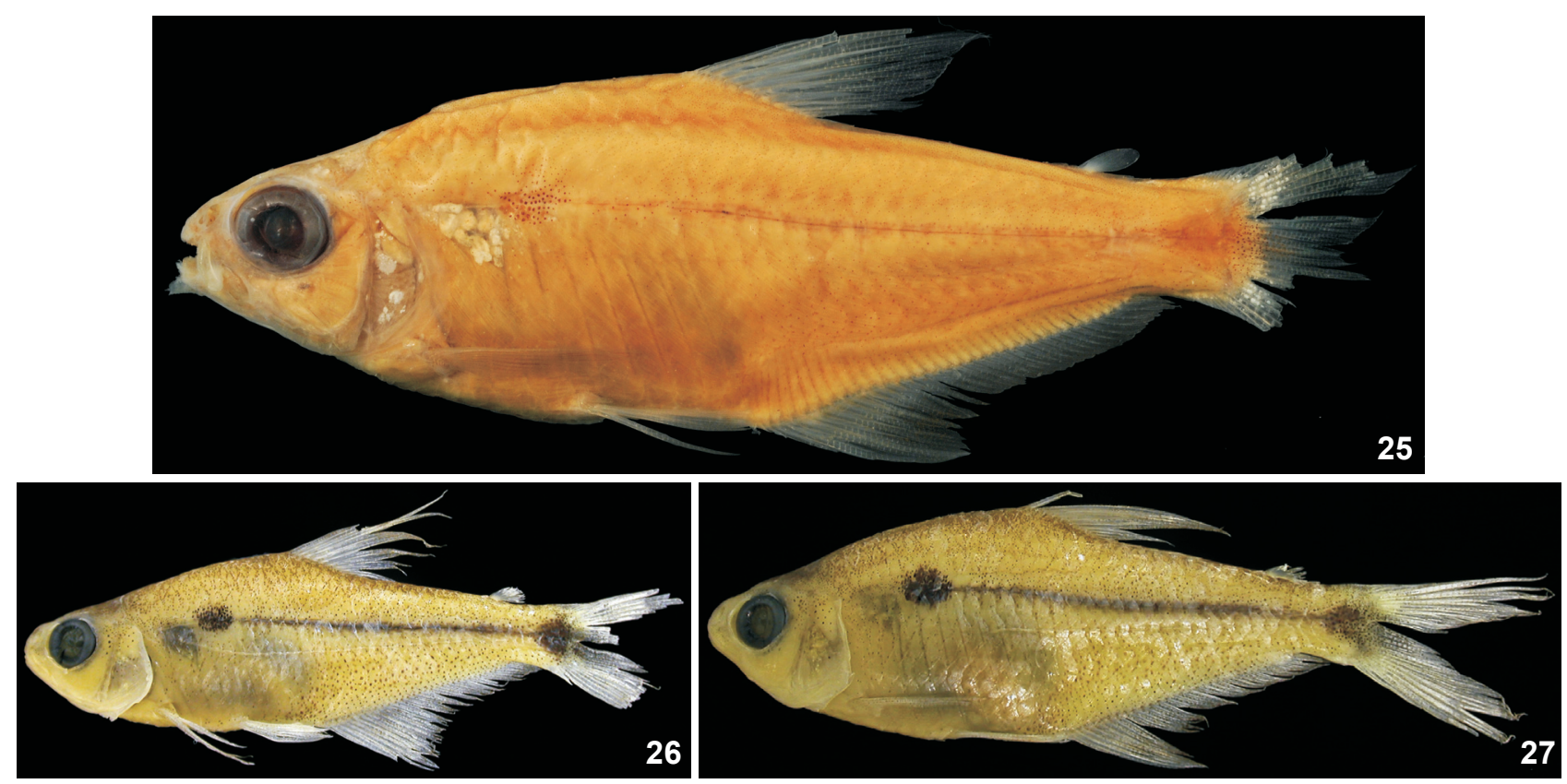

Figuras 25-27. Phenacogaster calverti: (25) ANSP 69606, holótipo, 38,8 mm CP, Fortaleza, Ceará. Foto Kyle Luckenbill; (26) MCP 30683, macho, 30,8 mm CP e (27) MCP 30683, fêmea, 36,4 mm CP, Rio Piranhas, Paraíba. Comparar a forma da nadadeira anal de macho e fêmea.

rior alcançando a margem vertical do pré-opérculo; dentes da fileira externa do pré-maxilar interrompida, com 1-5 dentes totais, linha lateral completa, com 35-37 escamas perfuradas (média 35,7); 27-32 (média 29,5) raios ramificados na nadadeira anal, altura do corpo de 28,1-36,3\% no CP; diâmetro orbital $37,2-46,4 \%$ do CC; comprimento do maxilar de 22,5-27,7 no CC em espécimes acima de $30 \mathrm{~mm}$ de CP.

Dimorfismo sexual. Foram examinados 51 machos de 23,7 a 35,3 mm de CP. Apresentam ganchos nas nadadeiras anal e pélvicas. A nadadeira anal possui ganchos retrorsos situados desde o último raio não-ramificado até oitavo ou décimo primeiro raio ramificado, dispostos látero-posteriormente no segundo ramo; normalmente um, raramente dois ganchos por segmento. As nadadeiras pélvicas possuem ganchos retrorsos que podem estar situados desde o primeiro raio não-ramificado até o penúltimo raio ramificado, dispostos, medialmente, ao longo de quase toda a extensão do raio, algumas vezes em ambos os ramos; ganchos, no ramo interno, maiores e mais numerosos. Machos, em geral, apresentam os oito primeiros raios da nadadeira anal mais desenvolvidos do que as fêmeas (Figs 26 e 27).

Distribuição. Sistema do Rio Parnaíba (Piauí) e desde a drenagem do Rio Curu (Ceará) até o Piranhas (Paraíba), nordeste do Brasil. Não há registro da espécie no sistema do Rio Jaguaribe.

Variação Geográfica. Os espécimes provenientes do sistema do Rio Parnaíba não se diferenciaram quanto aos caracteres merísticos e morfométricos das demais populações de $P$. calverti. Entretanto, na população do sistema do Rio Parnaíba a mancha umeral é geralmente arredondada, levemente vertical, e nas demais populações de $P$. calverti é, em geral, horizontalmente ovalada. Esses caracteres mostraram alguma variação nas duas populações e precisam ser melhor avaliados. Em vista disso, a população do Rio Parnaíba é considerada $P$. calverti.

Material examinado. Holótipo. BRASIL, Ceará: Fortaleza, R. Von Ihering leg., ANSP 69606, 38,8 mm CP. Também RX. Não-tipos. BRASIL, Ceará: reservatório Pentecoste (drenagem do Rio Curu, a sudeste de Pentecoste), 15/VII/1966, AUM 8025 (12, 25,7-36,1 mm CP); reservatório Pentecoste (drenagem do Rio Curu, a sudeste de Pentecoste), AUM 8057 (8, 25,5-39,8 mm CP); Rio Curu (limite com São Luis do Curu), AUM 20573 (1, 29,5 mm CP); Rio Caxitoré (afluente do Rio Curu, imediatamente abaixo do reservatório de Caxitoré, 16 km de Itapagé), AUM 20590 (1, 31,8 mm CP); Rio Curu (imediatamente acima da foz, Poço Doce, ao sul de Paracuru), AUM 21611 (1, 33,6 $\mathrm{mm} \mathrm{CP}$ ); reservatório Pentecoste (drenagem do Rio Curu), USNM 313900 (22, 21,7-35,0 mm CP). Paraíba: Pombal, Rio Piranhas, (643'32"S, 3747'50"W), 26/VII/2002, MCP 30683 (17, 24,5-32,7 mm CP); Coremas, MZUSP 16523 (25 examinados de 140, 33,2-41,7 mm CP, 2 d\&c 36,1 e 41,7 mm CP). Piauí: riacho Sumaré (na estrada Teresina/Bom Jardim, Teresina, sistema do Rio Parnaíba, 5¹9'15"S, 4248'29”W), 26/VII/1998, MCP 22093 (3, 19,7-32,8 mm CP); riacho dos Macacos (na estrada Teresina/Bom Jardim, Teresina, sistema do Rio Parnaíba, $\left.5^{\circ} 22^{\prime} 34^{\prime \prime} \mathrm{S}, 42^{\circ} 49^{\prime} 58^{\prime \prime} \mathrm{W}\right), \mathrm{MCP} 22103$ (210, 23,7-36,6 mm CP, 2, d\&c. 29,9 e 32,7 mm CP); Teresina, Boquinha Rio Poti, (sistema do Rio Parnaíba, 5¹6'26”S, 42³9'51”W), MCP 22683 (3, 
33,6-39,5 mm CP). Rio Grande do Norte: São Miguel, riacho afluente do Rio Apodi, (afluente do Rio Bonsucesso, 6 ${ }^{\circ}{ }^{\prime} 21^{\prime \prime} \mathrm{S}$, 38²0'56"W), MCP 30566 (1, 29,5 mm CP).

Comentários. GéRY (1972), ao redescrever a espécie com base no holótipo, mencionou a presença de pequenas escamas medianas na região pré-ventral. Embora a espécie possua uma escama localizada entre 1-7 pares de escamas pré-ventrais, não se constatou a presença dessas escamas no holótipo.

\section{Phenacogaster carteri (Norman, 1934)}

Figs 28-29

Vesicatrus carteri Norman, 1934: 336, figs A-C (descrição original, localidade-tipo: British Guiana [Guiana]. Forest stream tributary to the Cuyuni River.

Diagnose. A presença de linha lateral incompleta com 813 escamas perfuradas difere $P$. carteri das demais espécies descritas do gênero, com exceção de $P$. capitulatus, $P$. napoatilis e $P$. tegatus. A ausência de mancha umeral difere $P$. carteri de $P$. tegatus e de $P$. napoatilis (mancha umeral presente em fêmeas). Phenacogaster carteri distingue-se, ainda, de $P$. tegatus pela mancha no pedúnculo caudal estar ausente ou restrita a alguns cromatóforos (conspícua em P. tegatus). A maior altura do pedúnculo caudal em espécimes machos (9,9\% no CP no único macho identificado) difere $P$. carteri de $P$. napoatilis $(6,1-9 \%$ no $\mathrm{CP})$. Diferencia-se, ainda, dessa última espécie pelo maior comprimento do maxilar em espécimes maiores que $30 \mathrm{~mm}$ de $\mathrm{CP}$ $(6,9-7,6 \%$ vs 6,2-6,9\% no CP). O maior comprimento da cabeça em espécimes acima de $30 \mathrm{~mm}$ de $\mathrm{CP}(24,7-26,2 \%)$ difere $P$. carteri de $P$. capitulatus (21,5-24,4\% no CP). De $P$. capitulatus distinguese, adicionalmente, pela menor altura do corpo $(29,8-33,3 \%$ vs $34,1-39,4 \%$ no CP), maior comprimento do focinho $(5,2-7,2 \%$ vs $4,3-5,3 \%$ no CP) e maior comprimento do maxilar $(6,7-7,8 \%$ vs $5,8-6,7 \%$ no CP). A ausência de mancha umeral ( $v$ s presença em machos e fêmeas) e ausência de mancha no pedúnculo caudal ou restrita a poucos cromatóforos ( $\nu s$ mancha presente) diferem P. carteri de P. maculoblongus, espécie que ocorre na mesma área de distribuição (drenagem do Rio Cuyuni e baixo Rio Orinoco).

Dimorfismo sexual. Foi examinado um macho (holótipo) de 33,4 mm de CP. Apresenta ganchos sobre as nadadeiras peitorais e anal. Nas nadadeiras peitorais, os ganchos são bem desenvolvidos, retrorsos e dispostos ao longo da região medial do primeiro até o sétimo raio ramificado, com um, raramente dois ganchos em cada segmento. Na nadadeira anal há três pequenos ganchos sobre o quinto raio ramificado e dois sobre o sexto raio ramificado, um em cada segmento de raio.

Material examinado. Holótipo. GuiAna: (arroio na floresta, tributário do Rio Cuyuni), G. S. Carter leg., BMNH 1934.9.12:216 (33,4 mm CP). Macho. Parátipo. Guiana: (arroio na floresta, tributário do Rio Cuyuni), G.S. Carter leg., BMNH 1934.9.12:217 (29,5 mm CP). Não-tipos. Venezuela, Bolivar: confluência do Rio Caura e Rio Erebato (várias localidades na área), UF 78040 (43, 23,3-36,0 mm CP, 2 d\&c)
Distribuição. Drenagem do Rio Cuyuni, sistema do Rio Essequibo (Guiana) e sistema do Rio Caura, baixo Rio Orinoco, Venezuela. A distribuição da espécie no sistema do Rio Cuyuni é baseada somente no material-tipo, pois não foram encontrados exemplares adicionais de $P$. carteri no material proveniente desse sistema.

\section{Phenacogaster franciscoensis Eigenmann, 1911}

Figs $30-32$

Phenacogaster franciscoënsis Eigenmann, 1911: 173 (descrição original, prancha VI, fig. 3, localidade tipo: "Boqueiras, near mouth of Rio Porto" [Preto]).

Phenacogaster franciscoensis - Géry, 1972: 11 (nova grafia). Ibarra \& Stewart, 1987: 65 (localidade-tipo: Brasil: Boqueirão, próximo à foz do Rio Preto). - Malabarba \& Lucena, 1995: 338 (menção à localidade-tipo).

Diagnose. Diferencia-se do complexo P. pectinatus por apresentar mancha umeral larga presente em machos e fêmeas ( $v s$ estreita e presente somente nas fêmeas) e linha lateral completa com 34-37 escamas perfuradas (vs completa com 38-41). Das demais espécies do gênero difere por apresentar mancha umeral arredondada ou ovalada, situada acima ou no máximo atingindo levemente uma ou duas escamas da linha lateral; mancha umeral mais próxima do pseudotímpano do que da vertical que passa pela origem da nadadeira dorsal; mancha do pedúnculo caudal relativamente larga, expandida, principalmente, na parte superior do pedúnculo caudal, e não alcançando a região posterior da nadadeira adiposa; série externa do pré-maxilar, quando interrompida, com 4-7 dentes totais; série externa do pré-maxilar, quando interrompida, geralmente com dois, raramente com um dente na região medial; linha lateral com 34-37 escamas perfuradas (média $=35,7 ; \mathrm{n}=26$ ); 27-32 raios ramificados na nadadeira anal (média $=29,7 ; \mathrm{n}=62$ ); altura do corpo de 30,6-40,1\% no CP (média = 33,9); diâmetro orbital de 37,6-45,2\% no CC; espaço interorbital de 25,6-30,3\% no CC, terceiro infra-orbital relativamente pequeno, margem ventral separada da margem horizontal do pré-opérculo por um espaço de aproximadamente $1 / 4$ a $1 / 5$.

Dimorfismo sexual. Foram examinados 36 espécimes machos de 22,2 a 33,5 mm de CP. Apresentam ganchos nas nadadeiras pélvicas e anal. Nadadeira anal com ganchos retrorsos situados desde o último raio não-ramificado até o $11^{\circ}$ ou $12^{\circ}$ raio ramificado, dispostos látero-posteriormente no segundo ramo, um, raramente dois por segmento. Nadadeiras pélvicas com ganchos alongados e retrorsos que podem estar situados desde o primeiro raio não-ramificado até o penúltimo raio ramificado, dispostos, medialmente, ao longo dos ramos anterior e posterior. Machos, em geral, apresentam os raios da nadadeira anal mais desenvolvidos do que as fêmeas.

Material examinado. Holótipo. Brasil, Minas Gerais: Boqueirão, próximo à foz do Rio Preto (afluente do Rio Grande, sistema do Rio São Francisco), 6/I/1908, J. D. Haseman leg., 

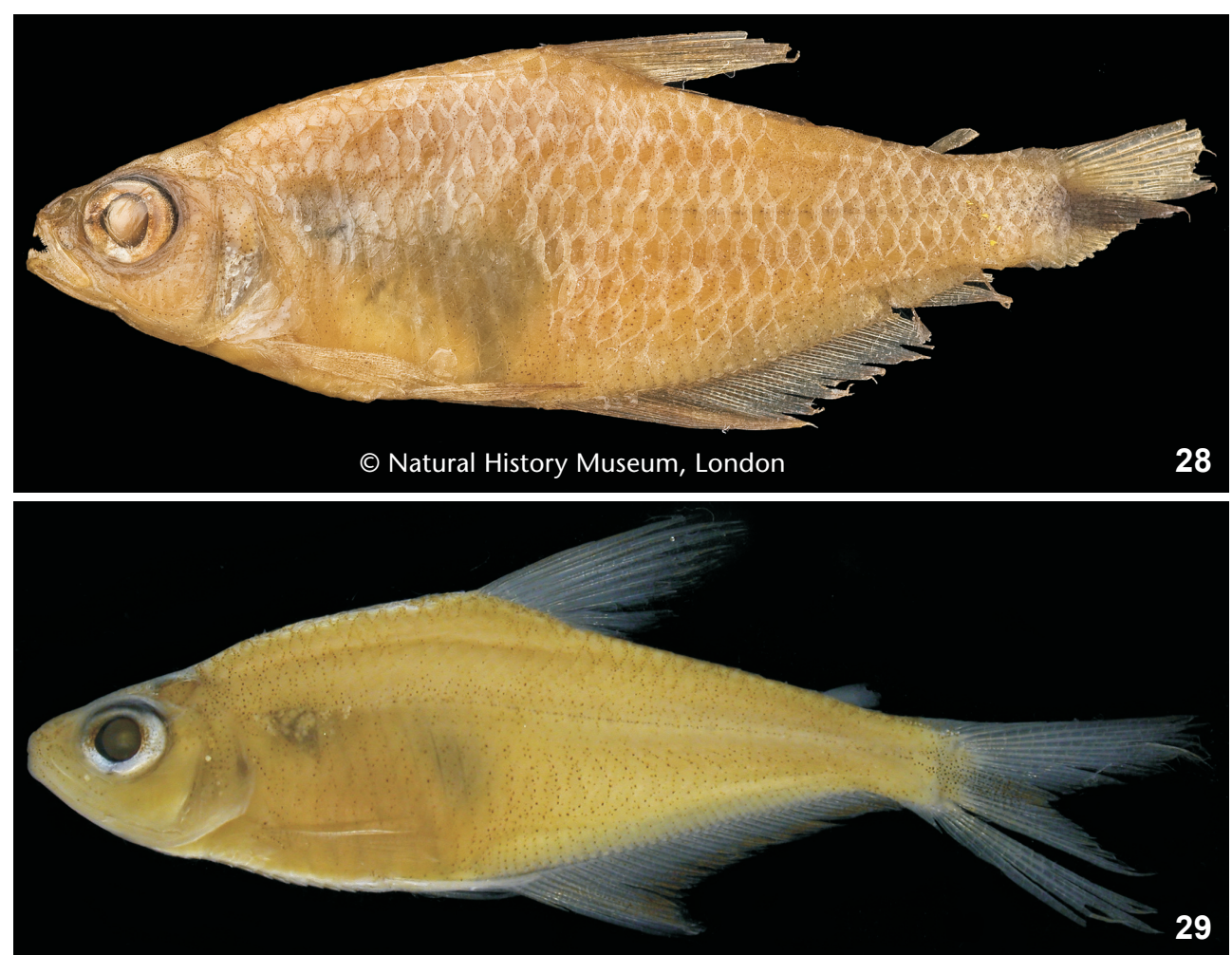

Figuras 28-29. Phenacogaster carteri: (28) BMNH 1934.9.12:216, holótipo, 36,4 mm CP, afluente do Rio Cuyuni, Guiana, (29) UF 78040, 30,4 mm CP, confluência dos rios Caura e Erebato, sistema do Rio Orinoco, Venezuela.
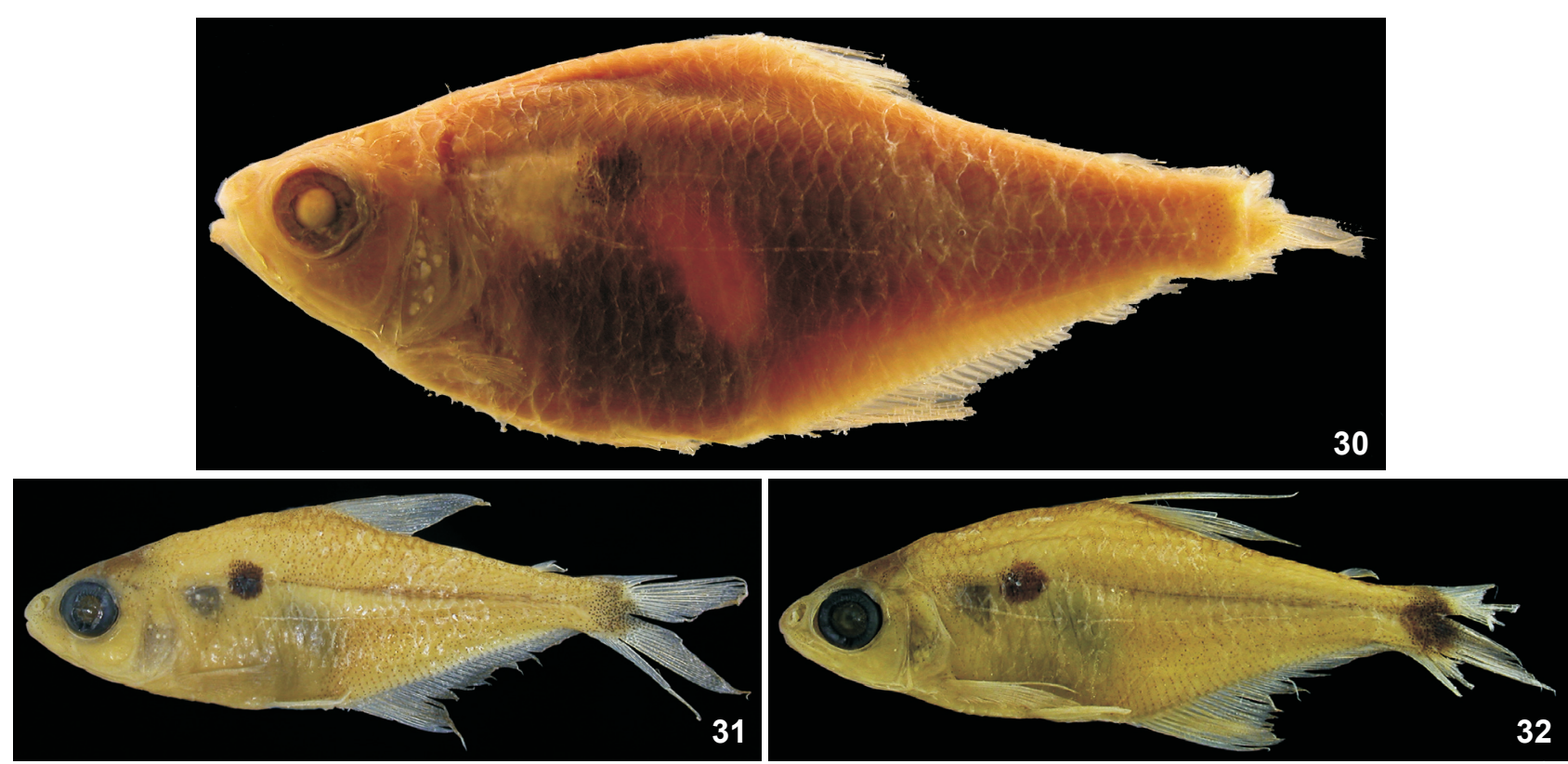

Figuras 30-32 Phenacogaster franciscoensis: (30) FMNH 54599, holótipo, 30,2 mm CP, Boqueirão, sistema do Rio São Francisco, Minas Gerais; (31) MCP 27816, fêmea, 27,5 mm CP, Rio Pirapitinga, sistema do Rio São Francisco, Minas Gerais; (32) MCP 32531, macho, 28,7 mm CP, Rio Juramento, sistema do Rio São Francisco, Minas Gerais. Comparar a forma da nadadeira anal de macho e fêmea. 
FMNH 54599 (30,2 mm CP). Parátipos. Brasil, Minas Gerais: Boqueirão, próximo à foz do Rio Preto (afluente do Rio Grande, sistema do Rio São Francisco), 6/I/1908, J. D. Haseman leg., FMNH 54600 (2 de 3, 28,4-29,1 mm CP); Santa Rita, Rio Preto e tributários (sistema do Rio São Francisco), 24/I/1908, J. D. Haseman leg., FMNH 54601 (2 de 4, 29,9-30,9 mm CP); Januária, Rio São Francisco, J.D. Haseman leg., FMNH 54603 (3 de 5, 30,4- 31,7 mm CP). Não-tipos. Brasil, Bahia: Barra do Côcos,

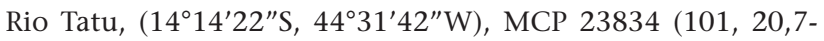
39,4 mm CP, 2 d\&c); Palmeiras, Rio Santo Antônio (12 $25^{\prime} 26^{\prime \prime}$, 4121'48”W), MNRJ 21267 (20 de 59, 22,4-44,8 mm CP); Itaetê, braço do Rio Una (bacia do Rio Paraguaçu), MZUSP 49239 (12, 26,9-39,2 mm CP); São Desidério, Rio São Desidério, MZUSP 58266 (69, 16,1-33,4 mm CP). Minas Gerais: Rio Juramento (a jusante da barragem de Juramento, afluente do Rio Verde Grande, sistema do Rio São Francisco, $\left.16^{\circ} 45^{\prime 2} 20^{\prime \prime} \mathrm{S}, 43^{\circ} 39^{\prime} 56^{\prime \prime} \mathrm{W}\right)$, MCP 32531 (4, 27,2-29,6 mm CP); distrito Fabião I, Rio Peruaçu,

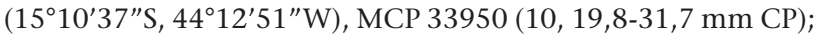
arroio Salinas $(51 \mathrm{Km}$ a oeste de Monte Azul, 15 12'53"S, $\left.43^{\circ} 15^{\prime} 49^{\prime \prime} \mathrm{W}\right)$, MCP 44005 (55, 19,5-21,1 mm CP); Rio da Cruz (estrada entre Januária-Fabião, $15^{\circ} 20^{\prime} 44^{\prime \prime} \mathrm{S}, 44^{\circ} 14^{\prime} 02^{\prime \prime} \mathrm{W}$ ), MCP 44008 (25, 19,2-26,7mm CP); arroio em São João das Missões (estrada Itacarambi-Manga, $14^{\circ} 52^{\prime} 46^{\prime \prime} \mathrm{S}, 44^{\circ} 05^{\prime} 00^{\prime \prime} \mathrm{W}$ ), MCP 44006 (50, 23,3-35,7 mm CP); Rio Verde Grande (estrada Montes Claros-Janaúba, 16³9'01"S, 4342'49”W), MCP 44007 (28, 19,6-39,8 mm CP); Presidente Juscelino, Rio Cipó, (1841’12"S, 4359'51”W), MCP 34065 (7, 15,5-27,7 mm CP); Côcos, Rio

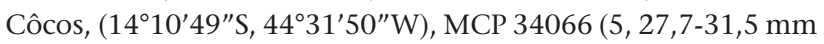
CP). Pernambuco: Cabrobró, arroio na estrada BR116, $\left(8^{\circ} 40^{\prime} 02^{\prime \prime}\right.$, 3859'26”W), MCP 31197 (32, 26,5-38,8 mm CP).

Distribuição. Sistema do Rio São Francisco e Rio Paraguaçu.

Comentários. Uma das principais características da espécie fornecida por EigenMann \& Myers (1929) e Géry $(1972,1977)$ para distinguí-la de outras do gênero é a presença de fileira externa de dentes do pré-maxilar contínua, semelhante à encontrada em P. megalostictus. O exame do holótipo mostrou que há um pequeno espaço entre o segundo e o terceiro dente na série externa do pré-maxilar esquerdo. No pré-maxilar direito o estado dos dentes é relativamente precário, pois falta a maioria deles na região entre os dois primeiros tricúspides mais laterais e os quatro últimos cônicos menores (um deles posicionado mais à frente). Da mesma forma, em um dos páratipos dos lotes FMNH 54601 (29,5 mm CP) e FMNH 54600 (29,1 mm CP), o pré-maxilar esquerdo apresenta espaço entre o segundo e terceiro dentes (no lado direito faltam dentes), e em outro parátipo do lote FMNH 54603 (32,2 mm CP), ambos os pré-maxilares também apresentam espaço entre o segundo e terceiro dente, não havendo indícios de perda de dente. Em dois parátipos do lote FMNH 54603 constatou-se a presença da fileira contínua nos pré-maxilares esquerdo e direito. O exame de material adicional de $P$. franciscoensis mostrou que o caráter é variável.
Phenacogaster jancupa Malabarba \& Lucena, 1995

Phenacogaster jancupa Malabarba \& Lucena, 1995: 337 (descrição original, localidade-tipo: Brasil: Mato Grosso: "Jangada, ribeirão Espinheiro, Rio Cuiabá drainage, $15^{\circ} 24^{\prime} \mathrm{S} 56^{\circ} 23^{\prime} \mathrm{W}^{\prime \prime}$ ).

Diagnose. Phenacogaster jancupa difere do complexo $P$. pectinatus por apresentar conspícua mancha umeral em ambos os sexos ( $v s$ ausente ou restrita a poucos cromatóforos em machos); conspícua mancha no pedúnculo caudal (vs ausente ou restrita a poucos cromatóforos); 29-33 raios ramificados (vs 33 ou mais). Das demais espécies do gênero diferencia-se pelo seguinte conjunto de caracteres: mancha umeral arredondada, situada acima das escamas da linha lateral; mancha do pedúnculo caudal com seu limite anterior não alcançando a vertical que passa pela extremidade posterior da nadadeira adiposa; linha lateral completa com 37 a 38 escamas perfuradas, comprimento da cabeça de $23,8-26,7 \%$ do $\mathrm{CP}$, terceiro infraorbital comparativamente pequeno, separado da margem horizontal do pré-opérculo por um espaço de $1 / 3$ a 1/4, raramente $1 / 5$ do seu comprimento, e ausência de ganchos nas nadadeiras peitorais. Da espécie simpátrica, $P$. tegatus, que também possui mancha umeral e mancha do pedúnculo caudal conspícua, diferencia-se facilmente por apresentar a mancha umeral mais próxima do pseudotímpano do que da vertical que passa pela origem da nadadeira dorsal ( $v s$ mancha imediatamente à frente ou na vertical que passa pela origem da nadadeira dorsal).

Material examinado. Holótipo. Brasil, Mato Grosso: Jangada, Ribeirão Espinheiro (drenagem do Rio Cuiabá, sistema do Rio Paraguai, $\left.15^{\circ} 24^{\prime} \mathrm{S}, 56^{\circ} 23^{\prime} \mathrm{W}\right)$, 10/VIII/1991, L.R. Malabarba, R.E. Reis, N.A. Menezes, M. Weitzman \& F.A. Machado leg., MCP 17279 (47,0 mm CP). Parátipos. BrasiL, Mato Grosso: Jangada, (Ribeirão Espinheiro (drenagem do Rio Cuiabá, sistema do Rio Paraguai, $15^{\circ} 24^{\prime}$ S, 56 $23^{\prime}$ W), 10/VIII/1991, L.R. Malabarba, R.E. Reis, N.A. Menezes, M. Weitzman \& F.A. Machado leg., MCP 16129 (32, 33,5-47,0 mm CP).

Distribuição. Conhecida somente da localidade-tipo: Jangada, ribeirão Espinheiro, drenagem do Rio Cuiabá, alto Rio Paraguai.

\section{Phenacogaster megalostictus Eigenmann, 1909} Figs 33-34

Phenacogaster megalostictus Eigenmann, 1909: 28 (descrição original, localidade-tipo: Tumatumari, Lower Potaro River). Eigenmann, 1912: 366, prancha LIII, fig. 3, prancha XCV (descrição; ilustração do holótipo; mapa das localidades do material-tipo). - Eigenmann, 1917: prancha 95, fig. 2 (RX do parátipo IU 11746). - Eigenmann, 1927: prancha 56, fig. 2 (ilustração do holótipo).

Diagnose. Phenacogaster megalostictus diferencia-se das demais espécies do gênero por apresentar 9-21 dentes (média = 16) dispostos ao longo de menos ou cerca da metade anterior da margem ventral do maxilar, (21 ou mais, dispostos, aproximadamente, até a extremidade posterior do maxilar, nas de- 

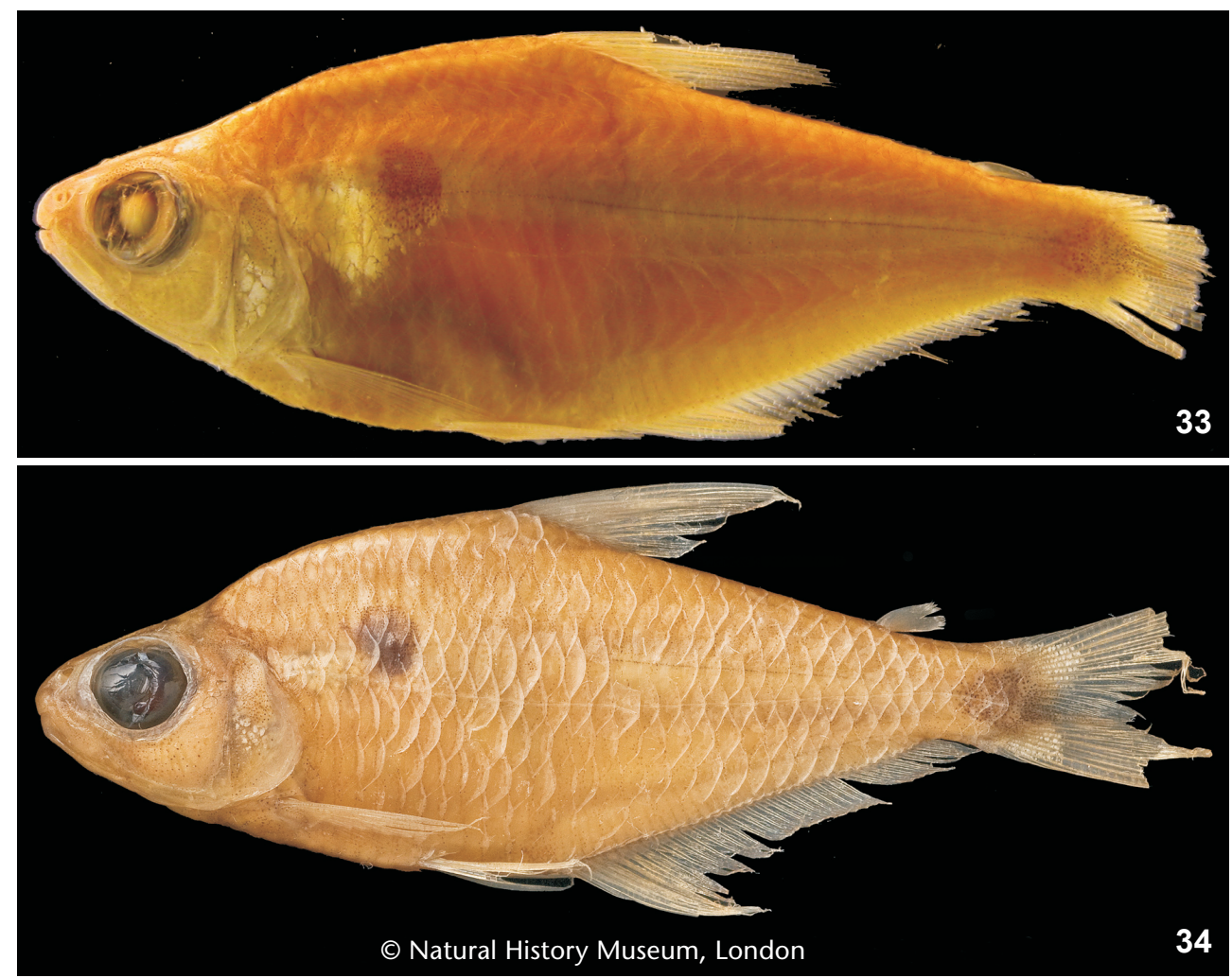

Figuras 33-34. Phenacogaster megalostictus: (33) FMNH 53530, holótipo, 49,2 mm CP, Tumatumari Rio Potaro inferior, Guiana. (34) BMHN 1974.5.22:82-85, Rio Potaro, 48,8 mm CP.

mais espécies, exceto $P$. maculoblongus com 20-30 dentes, $P$. tegatus com 18-29 e do Complexo $P$. pectinatus que raramente possui 20 dentes). Distingue-se, também, das demais espécies pela presença de uma contínua fileira externa de dentes no pré-maxilar, sem intervalo entre os dentes mediais e laterais, exceto de $P$. franciscoensis, $P$. napoatilis, $P$. prolatus, $P$. tegatus e $P$. wayampi, que podem apresentar ou não fileira contínua. Com exceção de $P$. prolatus, distingue-se, também, por apresentar uma mancha umeral relativamente grande sobre a linha lateral, podendo se estender até a metade das escamas da linha lateral (vs mancha umeral quando presente, situando-se acima da linha lateral ou, no máximo, alcançando levemente as escamas da linha lateral). O maior comprimento da cabeça, em relação ao CP, em espécimes menores do que 30,0 mm de CP $(28,1-$ $31,7 \%)$, permite diferenciar $P$. megalostictus da maioria das espécies do gênero (comprimento da cabeça de 23,8-28,9\% do CP), com exceção de $P$. ojitatus e de $P$. retropinnus. Da mesma forma, o diâmetro do olho em espécimes menores que $30 \mathrm{~mm}$ de CP é comparativamente maior em $P$. megalostictus do que nas demais espécies (12,4-14,4\% no CP vs 10,3-12,5\%), exceto de $P$. prolatus, da qual não foram examinados espécimes com esse tamanho. Duas espécies que ocorrem no mesmo sistema também possuem mancha umeral conspícua - P. maculoblongus e $P$. simulatus. Da primeira, difere adicionalmente por apresentar mancha umeral arredondada ou semicircular ( $v s$ verticalmente alongada) e 33-37 (média 35) escamas perfuradas na linha lateral (vs 37-39, média 37,5); da segunda, diferencia-se pela maior altura do corpo em espécimes maiores que $30 \mathrm{~mm}$ de CP $(30,4-38,4 \%$ vs $27,3-31,7 \%$ do CP) e focinho relativamente menor (Fig. 13).

Dimorfismo sexual. Foram examinados 13 machos de 40,2 a 50,3 mm de CP. Apresentam ganchos sobre as nadadeiras peitorais (visualizados a partir de $44 \mathrm{~mm}$ de CP em espécimes não-diafanizados e em dois espécimes diafanizados com 41,5 e 46,4 mm de CP), pélvicas e anal. Nadadeira anal com ganchos retrorsos que podem estar situados desde o último raio não-ramificado até o sétimo raio ramificado ou até o décimo (em um único espécime), dispostos látero-posteriormente, no segundo ramo; um ou dois ganchos em cada segmento. Nadadeiras pélvicas com ganchos retrorsos, desde o primeiro até o penúltimo raio ramificado, dispostos medialmente no segundo ramo; um gancho em cada segmento. Ganchos nas nadadeiras peitorais extremamente reduzidos (algumas vezes nãovisualizados), dispostos na superfície lateral do ramo mais externo, principalmente, do terceiro ao sétimo raios ramificados, dois a três, raramente um gancho por segmento. 
Material examinado. Holótipo. GuIAna: Tumatumari, Rio Potaro inferior, 1908, C. H. Eigenmann leg., FMNH 53530, originalmente CM 1056 (49,2 mm CP). Parátipos. Guiana: Rockstone, Rio Essequibo, 29/IX a 4/X/1908, C. H. Eigenmann leg., FMNH 52703 (3 de 5, 31,9-42,3 mm CP); Crab Falls, Rio Essequibo, C.H. Eigenmann leg., FMNH 52704 (3 de 5, 32,048,0 mm CP); Tumatumari, Rio Potaro inferior, 1908, C.H. Eigenmann leg., FMNH 53531 (5 de 10, 36,5-60,9 mm CP), FMNH 75168 (10 de 20, 32,0-49,6 mm CP); Tumatumari, Rio Potaro inferior, $\left(5^{\circ} 22^{\prime} \mathrm{N} 59^{\circ} 0^{\prime} \mathrm{W}\right.$, coordenadas aproximadas), 69/X/1908, C.H. Eigenmann leg., MCZ 29955 (1 de 2, 52,2 mm CP); Rockstone, Rio Essequibo, 29/IX/1908, C.H. Eigenmann leg., MCZ 29956 (1, 33,9 mm CP). Não-tipos. Guiana, CuyuniMazaruni: Rio Essequibo (praia, 1,15 km a SW de Rockstone, 5058'34"N 58033'19"W), J. W. Armbruster et al. leg., AUM 27785 (30, 20,7-32,7 mm CP). Upper Demerara-Berbeci: Rockstone, Gluck Island, Rio Essequibo, C.H. Eigenmann leg., CAS 70946 (1, 25,0 mm CP). Potaro-Siparuni: Rio Potaro (praia na margem N, abaixo de Tumatumari Falls, sistema do Rio Essequibo, $\left.5^{\circ} 21^{\prime} 48^{\prime \prime} \mathrm{N}, 59^{\circ} 00^{\prime} 04^{\prime \prime} \mathrm{W}\right)$, J.W. Armbruster et al. leg., AUM 28057 (32, 33,0-49,4 mm CP; 2 de 40,2 e 41,5 mm CP, machos, d\&c); Rio Potaro (abaixo de Amatuk Fall, sistema do Rio Essequibo), BMNH 1974. 5. 22: 82-85 (4, 46,2-50,2 mm CP); Kangaruma, Rio Potaro (canal lateral do Rio Potaro, sistema do Rio Essequibo, $\left.5^{\circ} 20^{\prime} \mathrm{N}, 59^{\circ} 13^{\prime} \mathrm{W}\right)$, E. Holm \& C. Thalman leg., ROM 61528 (2, 42,6-58,1 mm CP); Mahdia, Rio Potaro (Amatuk Fall, canal lateral do Rio Potaro, próximo a Portage, sistema do Rio Essequibo, $\left.5^{\circ} 18^{\prime} \mathrm{N}, 59^{\circ} 18^{\prime} \mathrm{W}\right), 2 / \mathrm{X} / 1990$, ROM 61529 (4, 46,459,1; 1 macho de 46,4 mm CP d\&c); riacho em Kurupukari Falls $\left(4^{\circ} 39^{\prime} 37^{\prime \prime} \mathrm{N}, 58^{\circ} 40^{\prime} 53^{\prime \prime} \mathrm{W}\right), 7 / \mathrm{X} / 1990$, E. Holm et al. leg., ROM 64233 (9, 22,2-42,1 mm CP).

Distribuição. Drenagens dos rios Potaro e Essequibo, sistema do Rio Essequibo.

Comentários. Myers in Eigenmann \& Myers (1929: 448) registrou em nota de rodapé a provável ocorrência de $P$. megalostictus no Rio Negro, o que foi repetido por Géry (1972: 12, 1977: 530). Não foram encontrados exemplares dessa espécie no extenso material examinado do Rio Negro, mas sim de outra muito similar - identificada aqui como uma nova espécie, $P$. prolatus, a qual também possui dentes do pré-maxilar formando uma fileira contínua e uma grande mancha umeral, estendendo-se sobre as escamas da linha lateral. Entretanto, $P$. megalostictus diferencia-se dessa espécie por apresentar infraorbital 3 maior, o qual pode alcançar a margem posterior do pré-opérculo e quase alcança a margem inferior (distante da margem posterior e inferior em $P$. prolatus), maior comprimento pré-anal $(50,8-58,6 \%$ vs $47,8-52,6 \%$ do CP), maior altura do pedúnculo caudal (7,5\%-10,1\% vs 6,4\%-7,9\% no comprimento padrão em espécimes acima de $30 \mathrm{~mm}$; Fig. 9) e presença de mancha no pedúnculo caudal em espécimes machos e fêmeas (ausente em $P$. prolatus). As diferenças encontradas entre o material-tipo examinado e a descrição original de EigENMANN (1909) referem-se somente à contagem do número de dentes da fileira externa do pré-maxilar e do maxilar. EIgENMANN (1909) indica 4-7 dentes na fileira externa do pré-maxilar e 11-16 dentes. Entretanto, ao examinar o holótipo, verificou-se a presença de oito dentes em ambos os lados do pré-maxilar e no exame dos parátipos, oito ou nove dentes em um único lado do osso. Quanto ao número de dentes do maxilar, embora a maioria esteja dentro dos limites apresentados por EIGENMANN (1909), a variação encontrada foi de 9-21 dentes.

O segundo suborbital mencionado na descrição de Eigenmann (1909: 29; 1927:449) e EigenMann \& Myers (1929: 449) - "Second suborbital corrugate, leaving a wide naked margin" - refere-se certamente ao terceiro infra-orbital. O material-tipo de P. megalostictus diferencia-se do material examinado da AUM por apresentar forte concavidade na base do processo supraoccipital e maior altura do corpo em indivíduos acima de 40 mm de CP. Entretanto, não houve diferença nos demais caracteres.

\section{Phenacogaster tegatus (Eigenmann, 1911)}

\section{Fig. 35}

Vesicatrus tegatus Eigenmann, 1911: 174, Plate VII, fig. 1 (descrição original, localidade-tipo: Jaurú, Upper Paraguay basin [Campos Alegre, Rio Jauru, into Rio Paraguay, conforme localidades das coletas de Haseman em Eigenmann, 1911]). - Ibarra \& Stewart, 1987: 85 (holótipo: CM 3201 perdido). Eschmeyer, 1998: 1657 (holótipo: FMNH, ex CM 3201, perdido ou nunca no FMNH).

Phenacogaster tegatus - Malabarba \& Lucena, 1995: 338 (nova combinação).

Diagnose. A presença de conspícua mancha umeral localizada imediatamente à frente ou parcialmente sobre a vertical que passa pela origem da nadadeira dorsal diferencia Phenacogaster tegatus de todas as demais espécies do gênero. Esse caráter, encontrado unicamente em $P$. tegatus, é considerado uma autapomorfia da espécie.

Dimorfismo sexual. Não foi identificado dimorfismo sexual nos espécimes examinados.

Material examinado. Brasil, Mato Grosso: Barra do Bugres, Rio Bugres, (sistema do Rio Paraguai), MCP 17388 (12, 22,128,4 m CP); Ribeirão Chiqueirão (oeste de Jangada, afluente do Rio Cuiabá, sistema do Rio Paraguai), MCP 17389 (6, 24,0-30,1 mm CP); arroio na estrada Barra do Bugres-Cáceres (ao sul de Barra do Bugres, afluente do Rio Paraguai), MCP 17390 (29, 18,4-33,1 mm CP); arroio Caramujo (estrada Cuiabá-Porto Velho, a noroeste de Cáceres, afluente do Rio Paraguai), MCP 17387, (18, 23,5-27,8 mm CP); Cáceres, Rio Paraguai, MCP 17391 (21, 20,6-30,6 mm CP); arroio na estrada Barra do BugresCáceres (Porto Estrela, ao sul de Barra do Bugres, MCP 17392 (23, 18,2-25,5 mm CP).

Distribuição. Sistema do Rio Paraguai e, conforme Casciotta et al. (2003), também no sistema do Rio Paraná, na província de Corrientes. 


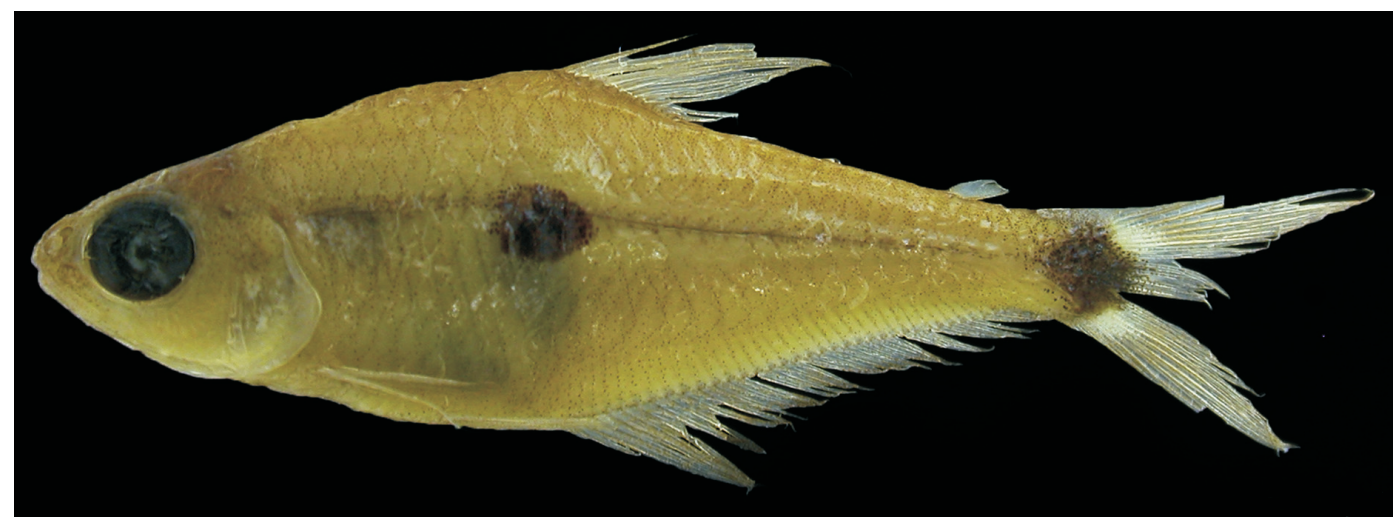

Figuar 35. Phenacogaster tegatus, MCP 17387, 26,0 mm CP, arroio Caramujo, sistema do Rio Paraguai, Mato Grosso.

Comentários. A espécie foi descrita por EIgenMann (1911) com base em nove espécimes: um espécime de $33 \mathrm{~mm}$ de $\mathrm{CP}$, da localidade de Jauru (alto Rio Paraguai), designado como holótipo (CM 3201), sete parátipos (CM 3202) de 31 a $33 \mathrm{~mm}$ de CP, da mesma localidade, e um parátipo de $30 \mathrm{~mm} \mathrm{CP} \mathrm{(CM}$ 3202), de Cáceres (alto Rio Paraguai). Eigenmann \& Myers (1929), ao redescreverem a espécie, listam no material examinado, diferente número de catálogo para o holótipo (CM 3208) e não listam o parátipo de Cáceres, mas incluem dois espécimes (CM 3203) da mesma localidade, sem especificação de status de tipo. O holótipo está perdido e os seis parátipos, dentre os sete da descrição original, provenientes do Rio Jauru, estão depositados no Field Museum of Natural History (FMNH 15184; FMNH 54573). Outros dois parátipos (CAS 62257) estão depositados na California Academy of Science, ambos também provenientes de Jauru, totalizando oito parátipos provenientes de Jauru. Entretanto, somente sete parátipos de Jauru foram listados por EIgenMann (1911), e não oito. O único outro espécime de Jauru, além dos sete parátipos, refere-se ao holótipo, como já mencionado acima. O parátipo proveniente de Cáceres aparentemente não está depositado na CAS, FMNH e MCZ. Caso a localidade de coleta dos parátipos da CAS e do FMNH estiver correta, um dos espécimes pode ser o holótipo. Caso contrário, um dos parátipos é de Cáceres. Eigenmann (1911) e Eigenmann \& Myers (1929) citaram, como uma das características de Vesicatrus tegatus (= P. tegatus), a presença de fileira externa de dentes do pré-maxilar contínua, o que foi seguido por Géry (1977). A análise de material adicional proveniente da região da localidade-tipo da espécie mostrou que esse caráter é variável e raramente está presente. Três dos 86 espécimes examinados apresentaram fileira contínua; nos demais, a fileira é interrompida, com os dentes separados em uma região medial e outra lateral. O caráter "redução do canal látero-sensorial", indicado em Malabarba \& Lucena (1995) como uma autapomorfia da espécie, não é exclusivo. Também ocorre em $P$. carteri, $P$. napoatilis e $P$. capitulatus, necessitando ser melhor avaliado.

\section{DISCUSSÃO}

Phenacogaster contém até o momento 11 espécies consideradas válidas, a maioria das quais descritas na primeira metade do século passado. O exame de novas coleções, obtidas em diferentes áreas da região Neotropical e principalmente na segunda metade do século passado, permitiu o reconhecimento de nove espécies novas descritas aqui, quase duplicando o número de espécies reconhecidas para o gênero. Também permitiu registrar a presença de populações nos sistemas do Rio Xingu e do Tocantins-Araguaia, não analisadas aqui.

Neste estudo, além das espécies novas, foi possível diagnosticar sete das espécies descritas anteriormente $(P$. apletostigma, $P$. calverti, $P$. carteri, $P$. franciscoensis, $P$. jancupa, $P$. megalostictus e $P$. tegatus). As espécies $P$. pectinatus, $P$. microstictus, $P$. beni e $P$. suborbitalis (juntamente com seus sinônimos juniores Tetragonopterus bairdii Steindachner, 1882 e Tetragonopterus tabatingae Steindachner, 1876), são referidas conjuntamente em um grupo de ampla distribuição geográfica denominado Complexo $P$. pectinatus, como caracterizado anteriormente. Além dessas seis espécies nominais, várias populações não descritas de Phenacogaster compõem este grupo. Estas, porém, apesar de diferirem entre si em caracteres relacionados a contagens e medidas não puderam ainda ser reunidas em padrões consistentes que permitam o reconhecimento de uma ou mais espécies. As populações do Complexo P. pectinatus necessitam ainda de novos estudos revisivos a fim de poder determinar a real diversidade específica do grupo.

\section{AGRADECIMENTOS}

Pelo empréstimo, doação e permuta de material e pela solicitude com que colocaram o material de suas instituições à disposição agradecemos à Scott Schaefer (ANSP, atualmente no American Museum of Natural History), Mark Sabaj (ANSP), Jonathan Armbruster (AUM), Anne-Marie Hine e James Maclaine (NHM), Davida Catania (CAS), Barry Chernoff (Wesleyan University; na época, no FMNH), Mary Anne Rogers (FMNH), 
Geraldo M. dos Santos e Lucia Py-Daniel (INPA), Pierre-Yves Le Bail (INRA - Institut National de la Recherche Agronomique, Rennes), Francisco Provenzano e Antonio Machado-Allison (MBUCV), Karsten Hartel (MCZ), Sonia Müller (MHNG), Patrice Prusvost (MNHN), Paulo Buckup (MNRJ), Hernán Ortega (MUSM), Osvaldo Oyakawa (MZUSP), Helmut Wellwndorf (NMW, Naturhistorisches Museum Wien), Sven Kullander (NRM), Erling Holm e Marty Rouse (ROM), Jeffrey Stewart (SIUC), James Albert (UF, atualmente na University of Louisiana at Lafayette), Wilson Costa (UFRJ), Paulo Lucinda (UNT, Universidade Federal do Tocantins), Richard Vari (USNM) e Susan Jewett (na época, na USNM), Hans-Joachim Paepke e Peter Bartsch (ZMB, Museum für Naturkunde, Humboldt, Universität zu Berlin). Aos colegas Alexandre Clistenes, Carlos Figueiredo e Flávio Lima pela colaboração no envio de material proveniente de suas coletas. Agradecemos a Claude Ferrara (MNHN) pelas fotos dos holótipos de $P$. wayampi e $P$. wayana e à Zora Gabsi (MNHN) pela radiografia de $P$. wayampi; a James Maclaine (NHM) e Kyle Luckenbill (ANSP) pelas fotos dos holótipos de $P$. carteri e $P$. calverti, respectivamente; a Philip Willink (FMNH) pelas fotos dos holótipos de $P$. fransciscoensis e P. megalostictus; a Pablo Lehman e Vinicius Bertaco pelas fotos de $P$. carteri e $P$. simulatus, respectivamente, e a José Pezzi da Silva pelas fotos dos holótipos das demais espécies. À Sonia Fish-Muller (MHNG), Philippe Keith (MNHN) e Michel Jégu (IRD) pela participação no programa de inventário dos peixes de água doce da Guiana Francesa, cujos espécimes foram utilizados no presente trabalho. Ao Conselho Nacional de Desenvolvimento Científico e Tecnológico pelos auxílios recebidos (processos 303785/2007-1 e 479412/2008-1, LRM; processo 471543/2007-1, ZML).

\section{LITERATURA CITADA}

Casciotta, R.; A.E. Almirón; S. Sanchez \& J.A. Bechara. 2003. Phenacogaster tegatus (Eigenmann, 1911), un nuevo integrante de la ictiofauna continental Argentina. Revista de Ictiología 9 (1/2): 1-3.

Eigenmann, C.H. 1909. Reports on the expedition to British Guiana of the Indiana University and the Carnegie Museum, 1908. Report n. 1. Some new genera of fishes from British Guiana. Annals Carnegie Museum 6 (1): 4-54.

Eigenmann, C.H. 1911. New characins in the collection of the Carnegie Museum. Annals Carnegie Museum 8 (1): 164-181.

Eigenmann, C.H. 1912. The Freshwater fishes of British Guiana, including a study of the ecological grouping of species, and the relation of the fauna of the plateau to that of the lowlands. Memoirs of the Carnegie Museum 5 (1): I-XXII + 1-578.

Eigenmann, C.H. 1917. The American Characidae. Memoirs of the Museum of Comparative Zoology 43 (Part 1): 1-102.
Eigenmann, C.H. 1927. The American Characidae. Memoirs of the Museum of Comparative Zoology 43 (4): 311- 428.

Eigenmann, C.H. \& G.S. Myers.1929. The American Characidae. Memoirs of the Museum of Comparative Zoology 43 (5): 429-558.

EschmeYer, W.N. 1998. Catalog of Fishes. Center for Biodiversity Research and Information. California Academy of Sciences 2 (Spec. Publ. 1): 959-1820.

Fink, W.L. \& S.H. Weitzman. 1974. The so-called Cheirodontin fishes of Central America with descriptions of two new species (Pisces:Characidae). Smithsonian Contributions Zoology (172): 1-46.

FowLER, H.W. 1941. A collection of fresh-water fishes obtained in eastern Brazil by Rodolpho von Ihering. Proceedings of the Academy of Natural Sciences of Philadelphia 93: 123-199.

GÉRY, J. 1972. Corrected and supplemented descriptions of certain characoid fishes described by Henry W. Fowler, with revisions of several of their genera. Studies Neotropical Fauna 7: 1-35.

GérY, J. 1977. Characoids of the world. Neptune City. T.F.H. Publications, 672p.

Géry, J.; P. Planquette \& P.Y. Le Ball. 1991. Faune Characoide (Poissons Ostariophysaires) de l'Oyapock, l'Approuague et la Riviere de Kaw (Guyane Francaise). Cybium 15 (1 Suppl.): 1-69.

Géry, J. \& P. Planquette. 1982. Additions à la Faune Characoïde (Poissons Ostariophysaires) de la Guyane. Revue Française d'Aquariologie 9 (3): 65-76.

IbarRa, M. \& D.J. Stewart. 1987. Catalogue of type specimens of recent fishes in Field Museum of Natural History. Fieldiana Zoology, New Series, (35): 1-112.

Lucena, Z.M.S. \& C.S. Gama. 2007. Phenacogaster apletostigma, nova espécie de peixe do Estado do Amapá, Brasil (Characiformes, Characidae). Revista Brasileira de Zoologia 24 (1): 151-156.

Malabarba, L.R. \& Z.M.S. Lucena. 1995. Phenacogaster jancupa, new species, with comments on the relationships and a new diagnosis of the genus (Ostariophysi: Characidae). Ichthyological Exploration of Freshwaters 6 (4): 337-344.

Norman, J.R. 1934. A new characin fish of the genus Vesicatrus from British Guiana. Annals and Magazine of Natural History (Series 10) 14 (81): 336-338.

Planquette, P.; P. Keith \& P.Y. Le Bail. 1996. Atlas des poissons d'eaudouce de Guyane (Tome 1). Characiformes. Muséum National d'Histoire Naturelle, Ministère de l'Environnement. 431p.

Taylor, W.R. \& G.C. Van Dyke. 1985. Revised procedures for staining and clearing small fishes and other vertebrates for bone and cartilage. Cybium 9: 107-119.

Submitted: 02.I.2009; Accepted: 06.II.2010.

Editorial responsibility: Wolmar Wosiacki 